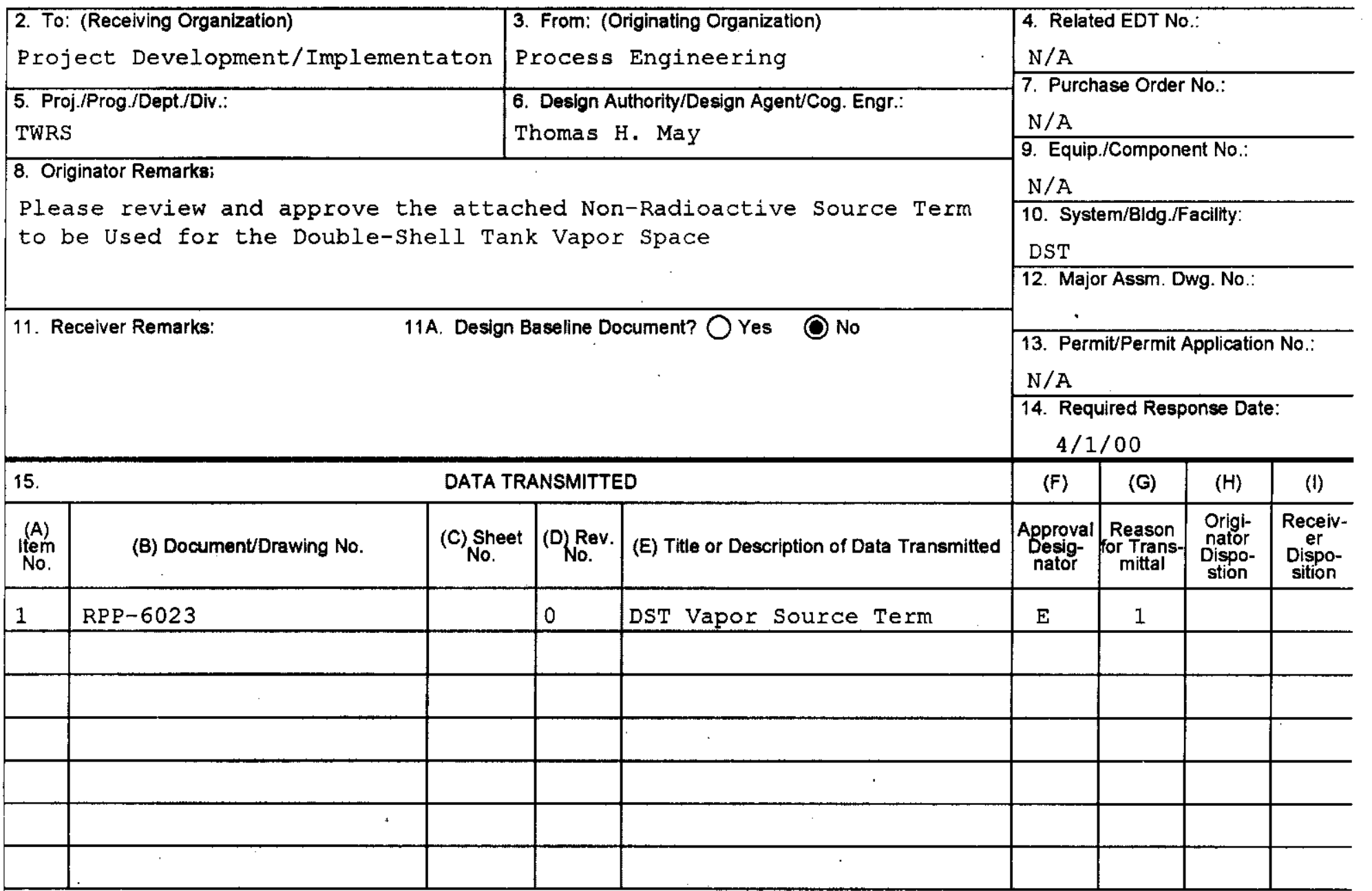

16.

\begin{tabular}{|c|l|}
\hline Approval Designator (F) & \\
\hline E, S, Q, D OR N/A & 1. Approval \\
$\begin{array}{c}\text { (See WHC-CM-3-5, } \\
\text { Sec. 12.7) }\end{array}$ & 2. Release \\
3. Information
\end{tabular}

17.

\begin{tabular}{|c|c|c|c|}
\hline $\begin{array}{l}\text { (G) } \\
\text { Rea- } \\
\text { son }\end{array}$ & \begin{tabular}{|l}
$(\mathrm{H})$ \\
Disp. \\
\end{tabular} & (K) Signature & (M) MSIN \\
\hline & & \multicolumn{2}{|l|}{ Design Authority } \\
\hline & & \multicolumn{2}{|l|}{ Design Agent } \\
\hline 1 & 1 & \multicolumn{2}{|c|}{ 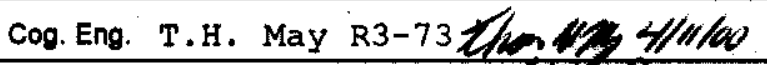 } \\
\hline 1 & $L$ & \multicolumn{2}{|c|}{ Cog. Mgr. N.w. Kirch R2-11/W/Lel $4 / 1 / \mathrm{aO}$} \\
\hline & & \multicolumn{2}{|l|}{ QA } \\
\hline & & \multicolumn{2}{|l|}{ Safety } \\
\hline 1 & 1 & Env M.G. Erlandson & \\
\hline
\end{tabular}
18.

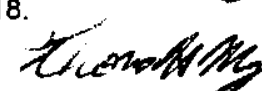

Signature of EDT Originator
T.H. May
Reason for Transmittal (G)

4. Review

5. Post-Review

6. Dist. (Receipt Acknow. Required)
KEY
Disposition (H) \& (1)

$\begin{array}{ll}\text { 1. Approved } & \text { 4. Reviewed no/comment } \\ \text { 2. Approved w/comment } & \text { 5. Reviewed w/comment } \\ \text { 3. Disapproved w/comment } & \text { 6. Receipt acknowledged }\end{array}$
3. Disepproved w/comment

6. Receipt acknowledged
SIGNATURE/DISTRIBUTION

(See Approval Designator for required signatures)

\begin{tabular}{ll|l|l|l} 
(M) MSIN Rea- & $(\mathrm{H})$ & (J) Name
\end{tabular}

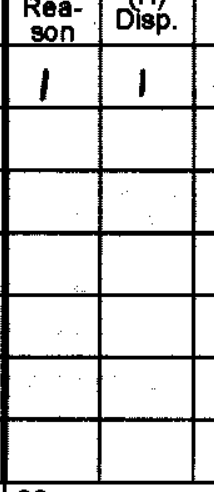

20.<smiles>C#CCCC1CC1C</smiles>

P.J. Certa

Authorized Representatlve for Receiving Organization
$4 / 13 / 00$

Date
N.W. Kirch

Design Authority/

Cognizant Manager
(J) Name GC Dewleese
(L) Date (M) MSIN

(K) Signature

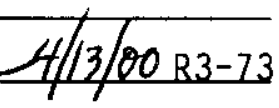

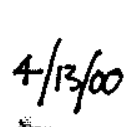

bate
21. DOE APPROVAL (if required)

Ctrl No.

Approved

Approved w/comments

Disapproved w/comments 
Distribution Continuation Sheet for EDT 628261

Reason for

transmittal

MI-SN

Operations

G.P. Duncan

R3-73

Retrieval Support Ops mgr

R.A. Dodd

3

R3-73

Industrial Safety

J.A. Ranschau

S7-86

$\operatorname{Rad}$ Con

S.K. Alexander

S7-86

R.M. Pierson

S7-75

Nuc Safety/License

T.G. Goetz

K.S.Tollefson

R1-49

Environmental

RCRA\&TSCA Serv mgr

Quality Assurance

B.G. Erlandson

R1-51

W.L.Adams

R1-51

Retrieval Engineering

Project Definition

A.B. Carlson

S6-15

C.E. Grenard

R3-73

Project Definition manager

Waste Feed Delivery

T.J. Conrads

R3-73

G.C. Deweese

R3-73

Tank Waste Retrieval \& Disposal

W. T. Thompson

R3-73

G.M. Crummel

R3-73

Environmental

N.A. Homan

R1-51

Environmental

C.H. Mulkey

G1-30

RCRA \& TSCA services

R.D. Potter

R1-51

Tank Waste Retrieval

Process Engineering

K.W. Kirch

R3-73

Process Engineering

Safety Analysis

Retrieval Engineering

D.A. Reynolds

W.L. Cowley

R2-11

P.J. Certa

R2-11

W.J. Millsap

R1-44

Retrieval Engineering

D.P. Fassett

R3-73

R3-73

Retrieval Engineering

C.A. Rieck

R3-73

Project W-211

Project W-521

DST Engineering

SST Engineering

K.A. White

D.G. Baide

R3-47

R.E. Larson

SST Waste Retrieval

V.F. FitzPatrick

R3-47

S5-05

T.H. May (5)

T4-07

Process Engineering

L.A. Fort

Process Engineering

D.C. Hedengren

S.D. Estey

R2-89

R2-11

R2-12

R2-11

R2-11 
RPP-6023

Rev. 0

\section{Nonradioactive Environmental Emissions Chemical Source Term for the Double-Shell Tank Vapor Space During Waste Retrieval Operations}

Prepared for the U.S. Department of Energy

Assistant Secretary for Environmental Management

\section{CH2MHILL Hanford Group, Inc.}

Richland, Washington

Contractor for the U.S. Department of Energy

Office of River Protection under Contract DE-AC06-99RL14047

Approved for Public Release; Further Dissemination Unlimited 


\title{
Nonradioactive Environmental Emissions Chemical Source Term for the Double-Shell Tank Vapor Space During Waste Retrieval Operations
}

\author{
T. H. May \\ CH2M Hill Hanford Group, Inc. \\ Richland, WA 99352 \\ U.S. Department of Energy Contract DE-AC06-96RL13200

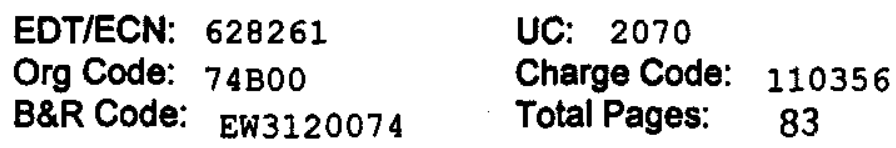

Key Words:

Vapor, Source Term, Tank Farms, Waste Retrieval, Environmental Emmissions

\section{Abstract:}

A nonradioactive chemical vapor space source term for tanks on the Phase 1 and the extended Phase 1 delivery, storage, and disposal mission was determined. Operations modeled included mixer pump operation and DST waste transfers. Concentrations of ammonia, specific volatile organic compounds, and quantitative volumes of aerosols were estimated.

TRADEMARK DISCLAIMER. Roference herein to any specific commercial product, process, or service by trade name, trademark, manufacturer, or otherwise, does not necessarily constitute or imply its endorsement, recommendation, or favoring by the United States Government or any agency thereof or its contractors or subcontractors.

Printed in the United States of America. To obtain coples of this document, contect: Document Control Services, P.O. Box 950, Mailstop H6-08, Richland WA 99352, Phone (509) 372-2420; Fax (509) 376-4989.
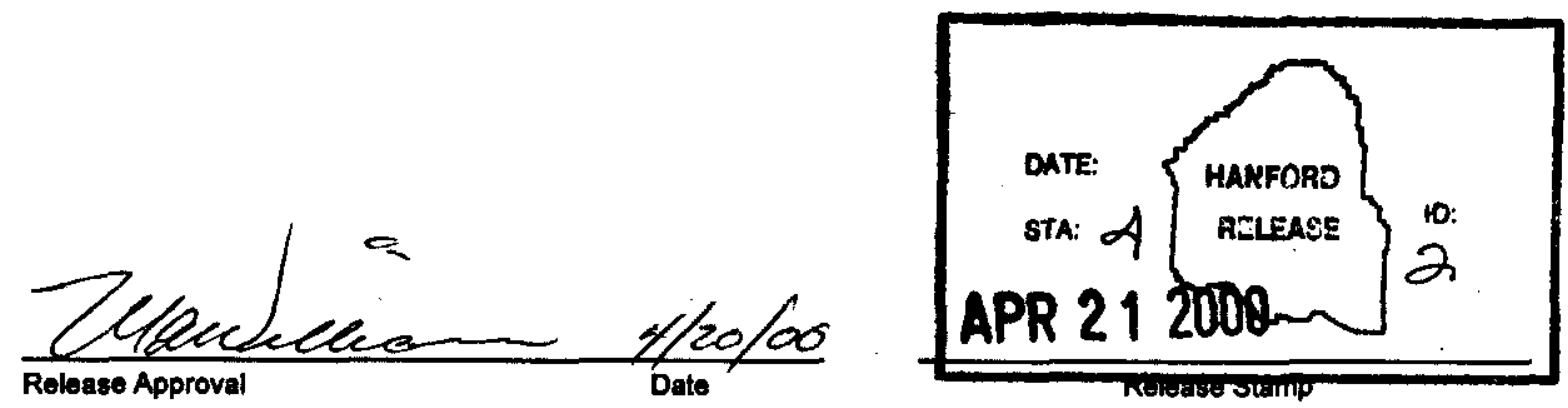

\section{Approved For Public Release}


RPP-6023

Rev. 0

\section{Nonradioactive Environmental Emissions Chemical Source Term for the Double-Shell Tank Vapor Space During Waste Retrieval Operations}

T. H. May

S. D. Estey

L. A. Fort

D. C. Hedengren

\section{CH2MHILL \\ Hanford Group, Inc.}

P. O. Box 1500

Richland, Washington

Contractor for the U.S. Department of Energy

Office of River Protection under Contract DE-AC06-99RL14047

Approved for Public Release; Further Dissemination Unlimited 


\section{LEGAL DISCLAIMER}

This report was prepared as an account of work sponsored by an agency of the United States Government. Neither the United States Government nor any agency thereof, nor any of their employees, nor any of their contractors, subcontractors or their employees, makes any warranty, express or implied, or assumes any legal liability or responsibility for the accuracy, completeness, or any third party's use or the results of such use of any information, apparatus, product, or process disclosed, or represents that its use would not infringe privately owned rights. Reference herein to any specific commercial product, process, or service by trade name, trademark, manufacturer, or otherwise, does not necessarily constitute or imply its endorsement, recommendation, or favoring by the United States

Government or any agency thereof or its contractors or subcontractors. The views and opinions of authors expressed herein do not necessarily state or reflect those of the United States Government or any agency thereof.

This report has been reproduced from the best available copy.

Available in paper copy and microfiche.

Available electronically at http://www,doe.gov/bridge. Available for a processing foe to the U.S. Department of Energy and its contractors, in paper, from:

U.S. Department of Energy

Office of Scientific and Technical Information

P.O. Box 62

Oak Ridge, TN $37831-0062$

phone: $865-576-8401$

fax: 865-576-5728

email: reports@adonis.osti.gov(423) 576-8401

Available for sale to the public, in paper, from:

U.S. Department of Commerce

National Technical Information Service

5285 Port Royal Road

Springfield, VA 22161

Phone: 800-553-6847

fax: 703-605-6900

email: orders@ ntis.fedworld.gov

online ordering:

http://www.ntis.gov/ordering.htm 


\section{TABLE OF CONTENTS}

1.0 INTRODUCTION.

2.0 SCOPE.

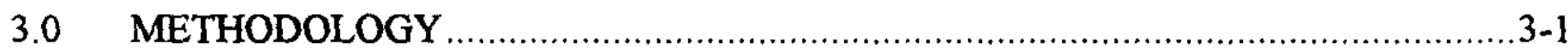

3.1 VOLATILE ORGANIC COMPOUND METHODOLOGY ….......................

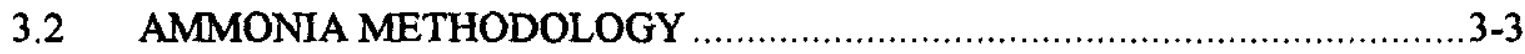

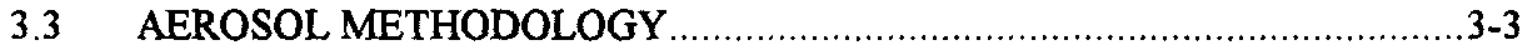

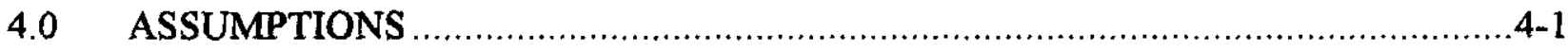

5.0 VOLATILE ORGANIC COMPOUNDS SOURCE TERM …..................................5-1

5.1 ORIGIN OF VOLATILE ORGANIC COMPOUNDS …............................5-1

5.2 DATA SOURCE FOR VOLATILE ORGANIC COMPOUNDS …................5-1

5.2.1 Tank Waste Information Network System ...................................... 5-1

5.2.2 241-C-106 Source Term Data.................................................... 5-4

5.2.3 Retained Gas Measurements.......................................................... 5-6

5.3 ESTIMATED VOLATILE ORGANIC COMPOUND SOURCE TERM ..........5-6

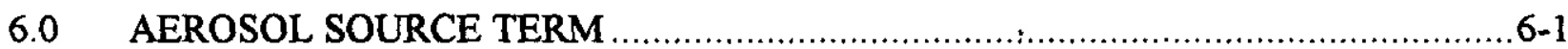

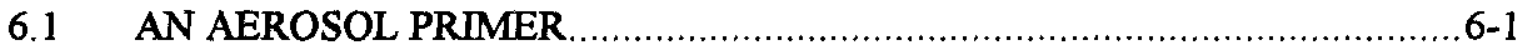

6.2 AEROSOL SIZE DISTRIBUTION .......................................................

6.3 AEROSOL MASS LOADINGS ……

6.4 ESTIMATED AEROSOL SOURCE TERM …..........................................6-6

7.0 AMMONIA SOURCE TERM

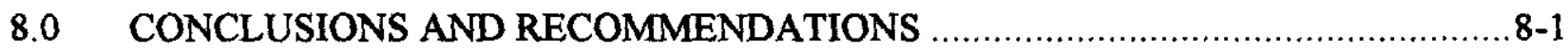

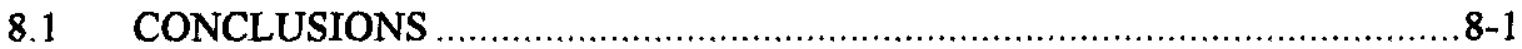

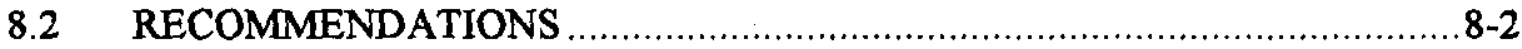

9.0 REFERENCES

\section{APPENDICES}

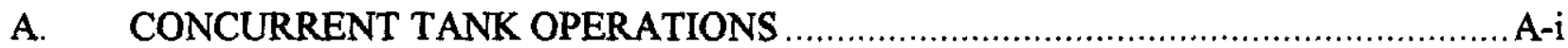

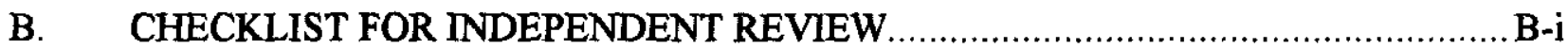

C. UNIT CONCENTRATION FACTORS FROM ISC3 ............................................

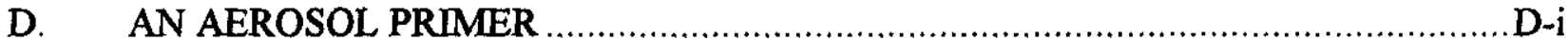

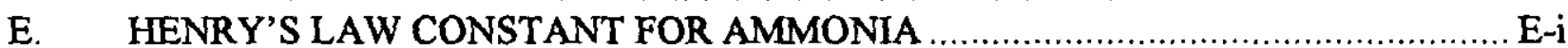

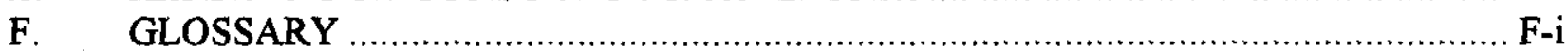


RPP-6023 REV 0

\section{FIGURES}

Figure 6-1. Maximum Stable Water Droplet Diameter. ............................................. 6-2

Figure 6-2. A Mechanical Aerosol Generator.......................................................6-3

Figure 6-3. Water Vapor Mass Loading at 100\% RH. ............................................... 6-4

Figure 6-4. Water Aerosol Mass Loading. ............................................................ 6-9

\section{TABLES}

Table 2-1. Listing of Evaluated Tanks. ...................................................................

Table 5-1. Tank Waste Inventories......................................................................

Table 5-2. Volatile Organic Compounds Source Term ............................................. 5-7

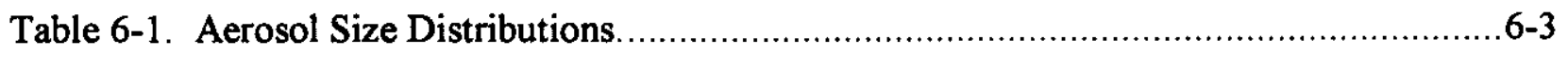

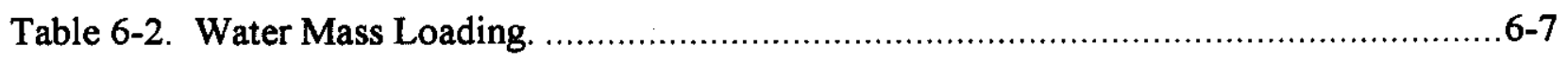

Table 6-3. Estimated Double-Shell Tank Headspace Aerosol Concentrations......................6-7

Table 7-1. Estimated Double-Shell Tank Stack Ammonia Concentrations....................... 7-2

Table 8-1. Volatile Organic Compounds and Ammonia Emissions....................................8-1 


\section{TERMS}

COC

DSS

DSSF

DST

GRE

HVAC

NOC

NPH

OGI

ORNL

PNNL

$\operatorname{Re}$

RH

RGS

SAS

SQER

TAP

VOC

WAC constituent of concern

double-shell slurry

double-shell slurry feed

double-shell tank

gas release event

heating ventilation and air conditioning

notice of construction

normal paraffin hydrocarbon

Oregon Graduate Institute

Oak Ridge National Laboratory

Pacific Northwest National Laboratory

Reynolds number

relative humidity

retained gas sampler

Special Analytic Support

small quantity emission rate

toxic air pollutant

volatile organic compounds

Washington Administrative Code 
RPP-6023 REV 0

This page intentionally left blank. 


\subsection{INTRODUCTION}

Alternatives Generation and Analysis for Double-Shell Tank Primary Ventilation Systems Emissions Control and Monitoring, HNF-4245, and the companion decision document, Decision Document for the DST Primary Ventilation Systems Emissions Control and Monitoring Decision, HNF-4384, recommended that dry adsorption beds be installed on double-shell tank (DST) ventilation systems for removal of volatile organic compounds and ammonia. This recommendation was made because of the lack of an approved nonradiological emission source term. Because no source term had been approved, the design recommendations had to be robust enough to handle contingencies including the potential for a very high volatile organic compound (VOC) and ammonia emission. This study refined the source term for ammonia, aerosol, and VOCs and suggests that dry adsorption beds need to be installed only on the SY farm. The dry adsorption beds would be needed for VOC, not for ammonia.

This engineering study did the following:

1. Estimated the concentrations of ammonia and specific volatile organic components (those present in sufficient quantities) that result during waste disturbance

2. Defined the nonradioactive chemical source terms for ammonia and those specific VOCs to be used in the design of treatment and monitoring equipment at the DST primary ventilation systems

3. Estimated the quantitative volumes of aerosols that could be produced when using a drop leg below the surface of the waste verses vapor space discharge during transfer operations. 
RPP-6023 REV 0

This page intentionally left blank. 


\subsection{SCOPE}

This study determined a nonradioactive chemical vapor space source term for tanks on the feed delivery, storage, and disposal mission summary document for case 3S5 and case 3S5 extended order revision 14 dated November 11, 1999, as described in Tank Waste Remediation System Operation and Utilization Plan to Support Waste Feed Delivery, HNF-SD-WM-SP-012. The differences between case 3S5 and 3S6D will not impact the source term. Case 3S6D adds tank 241-AP-108, which is dilute noncomplexed waste that will not be bounding for VOC, aerosols, or ammonia. Table 2-1 lists the tanks that were assessed. Tanks in parentheses represent singleshell tank (SST) waste retrieved to the DST listed above the SST.

Table 2-1. Listing of Evaluated Tanks.

\begin{tabular}{|c|c|c|c|}
\hline \multicolumn{2}{|c|}{ Low-Activity Waste } & \multicolumn{2}{|c|}{ High-Level Waste } \\
\hline Source & Staging & Source & Staging \\
\hline \multicolumn{4}{|c|}{ Case 3S5 } \\
\hline 241-AP-102 & 241-AP-102 & 241-AZ-101 & 241-AZ-101 \\
\hline 241-AP-104 & 241-AP-104 & 241-AZ-102 & 241-AZ-102 \\
\hline 241-AN-101 & 241-AN-101 & $\begin{array}{l}241-\mathrm{AY}-102 \\
(241-\mathrm{C}-106)\end{array}$ & 241-AY-102 \\
\hline 241-AN-102 & 241-AN-102 & $\begin{array}{l}241-\mathrm{AY}-101 \\
(241-\mathrm{C}-104)\end{array}$ & 241-AY-101 \\
\hline 241-AN-104 & 241-AN-104 & 241-SY-102 & 241-AZ-101 \\
\hline 241-AN-107 & 241-AN-107 & 241-AN-105 & 241-AN-105 \\
\hline 241-SY-101 & 241-AP-104 & 241-AN-103 & 241-AN-103 \\
\hline 241-AW-105 & 241-AN-105 & & \\
\hline \multicolumn{4}{|c|}{ Case 355 Extended Order } \\
\hline 241-AW-104 & 241-AP-104 & $\begin{array}{l}241-\mathrm{AY}-102 \\
(241-\mathrm{C}-107) \\
\end{array}$ & 241-AY-102 \\
\hline 241-SY-103 & 241-AN-101 & 241-AW-103 & 241-AY-102 \\
\hline 241-AP-106 & 241-AN-102 & 241-AW-104 & 241-AW-104 \\
\hline $\begin{array}{l}241-S Y-102 \\
(241-S-103)\end{array}$ & 241-AN-105 & & \\
\hline $\begin{array}{l}241-S Y-102 \\
(241-S-102) \\
\end{array}$ & 241-AN-105 & & \\
\hline 241-AP-101 & 241-AP-101 & & \\
\hline $\begin{array}{l}241-S Y-103 \\
(241-S-105) \\
\end{array}$ & 241-AW-101 & & \\
\hline 241-AP-105 & & & \\
\hline
\end{tabular}


This study developed emission source terms for waste feed delivery from the DSTs listed in Table 2-1. The kinds of operations modeled include mixer pump operation and waste transfer from one DST to another DST. Sluicing of waste from an SST to a DST was looked at only from the point of emissions from a DST. Emissions from sluicing are part of the SST program and are not included in this study. DSTs are emptied before receiving waste from SSTs. Waste sluiced from an SST to a DST will be injected below the surface of the DST supernate and will have the same source term as a transfer from a DST to a DST.

For self-containing low activity waste tanks, Retrieval Engineering is performing an Alternatives Generation and Analysis (AGA) to determine the preferred retrieval strategy. Recommendations thus far are to retrieve $241-\mathrm{AN}-103,-104,-105$, and $241-\mathrm{AW}-101$ by decanting the supernate and then backfilling with water. During the decanting phase, a GRE may be initiating. The backup strategy is to mix the waste first and then transfer the waste with dilution. For purposes of this analysis, the study chose the decant flowsheet because it is bounding. 


\subsection{METHODOLOGY}

The methodology for developing source terms for the three constituent of concern (COC) category source terms (ammonia, aerosol, and VOCs) was based on behavior of the COC and how the COC acts in the tank environment. Aerosols are generated by physical means; ammonia is largely dissolved in the waste and emitted when the waste is disturbed; VOC is present both as partially dissolved species and as retained gas.

\subsection{VOLATILE ORGANIC COMPOUND METHODOLOGY}

To determine a viable VOC source term, data were compiled from a number of sources. With this data and with assumptions and extrapolations listed in Section 4.0, source terms were estimated for the tanks identified in Table 2-1. (The spreadsheet containing the data and the calculations is on file with document control on a compact disc.) The worst source term for each organic compound derived for any one tank was selected and compared with the regulatory limits for COCs contained in Data Quality Objectives for Regulatory Requirements for Hazardous and Radioactive Air Emissions Sampling and Analysis, HNF-SD-WM-DQO-021; and Regulatory Data Quality Objectives Supporting Tank Waste Remediation System Privatization Project, PNNL-12040. These documents identify the analytes that are needed to address regulatory issues and that are known to be potentially in the tank waste. Regulatory limits from those references are given as small quantity emission rates (SQERs), which are stack concentrations, and as acceptable source impact levels (ASILs), which are dispersed rates (see Appendix C).

Where data were not available, conservative assumptions were made. As an example, the tank headspace VOC speciation data for 241-S-102 were available, as was retained gas sampling (RGS) information. The RGS data provided gas volumes retained in the waste, but only gave composition data for major constituents such as nitrogen, ammonia, methane, and nitrous oxide. To determine retained gas VOC speciation, methane was used as the "tie" component. The headspace VOC speciation data were multiplied by the ratio of methane in the tank waste retained gas to methane in the tank headspace to obtain the VOC speciation in the retained gas. The ratio of methane in the retained gas to methane in the headspace is 866 .

This approach should be conservative for soluble VOC and should apply to this study because DSTs in this study have supernate layers and SST waste retrieved to DSTs will have supernate layers caused by the sluicing process. Soluble VOC species are more readily evolved into the tank headspace than insoluble species when the waste is quiescent. For most of the SST headspace vapor samples, the tanks were quiescent. Methane is relatively insoluble in the waste and is more likely to be retained in the waste as gas. Consequently, methane concentrations retained in the waste will be relatively higher than methane concentrations in the headspace when compared with the concentrations of soluble VOC species. Multiplying the soluble VOC species by the methane ratio will estimate conservatively the soluble VOC concentrations when the waste is disturbed. 
This approach should yield representative results for slightly soluble and nonsoluble organics. This is by virtue of the way a retained gas sample and measurement are taken and because methane is a slightly soluble organic molecule. The retained gas sampler was inserted into the tank waste and hermetically sealed while in the waste in the tank. At the Pacific Northwest National Laboratory (PNNL), the sample was extruded into an evacuated chamber. The waste was stirred and the gases evolved were analyzed. Any VOC, whether gas, liquid, or dissolved, should be evolved and analyzed by this method.

For the VOC source term, the major contributor is a source tank with mixer pumps operating. For receiver tanks with active ventilation, the VOC source term is small compared with a source tank with a mixer pump. For quiescent tanks with active ventilation, the source term is negligible. The VOC source term therefore primarily depends on emissions from a source tank with mixer pumps operating. The VOC source term in this study assumes that the stack concentration is only from the source tank and that other tanks on the same heating, ventilation, and air conditioning (HVAC) header have zero emissions.

An estimate of the fraction of gas retained in phases (gas, liquid, dissolved) released during mixer pump operation (6\%) was applied to determine headspace VOC concentrations. The resulting tank headspace VOC concentration was then prorated based on HVAC flows to determine stack VOC emissions. Tank 241-SY-101 has an HVAC flow of $14.2 \mathrm{~m}^{3} / \mathrm{min}$ $\left(500 \mathrm{ft}^{3} / \mathrm{min}\right)$, whereas $241-\mathrm{SY}-102$ and $241-\mathrm{SY}-103$ have $5.7 \mathrm{~m}^{3} / \mathrm{min}\left(200 \mathrm{ft}^{3} / \mathrm{min}\right)$ each. The stack VOC concentration due to 241-SY-101 was then multiplied by 500/900.

The most complete information available for double-shell slurry feed (DSSF) is for 241-S-102. VOC source terms for other tanks of DSSF that had no data were prorated from 241-S-102. This is a reasonable assumption because 241-S-102 has the highest retained gas content of any of the tanks assessed in this study. The VOC source term for 241-S-102 was multiplied by the ratio of the retained gas volume of the other DSSF tank divided by the 241-S-102 retained gas volumes. Where retained gas volumes were not available, the VOC source term for 241-S-102 was multiplied by the ratio of the salt cake/sludge volumes of the other DSSF tank (241-AN-103, 241-AN-104, 241-AN-105, 241-AP-105, and 241-AW-101) divided by the 241-S-102 salt cake/sludge volumes. The 241-S-102 VOC source term also was prorated based on the ratio of the tank headspace for 241-S-102 versus the tank headspace for the other DSSF tank.

For Tank 241-C-106, tank headspace sampling data were obtained before and during sluicing and was used to estimate the VOC source term. Because this was the most complete data for noncomplexed waste, other tanks of noncomplexed waste that had no data were prorated from 241-C-106 data. The VOC source term for 241-C-106 was multiplied by the ratio of the salt cake/sludge volumes of the other noncomplexed waste tanks (241-AP-104, 241-AP-106, 241-AW-103, 241-AW-105, and 241-AY-102) divided by the 241-C-106 salt cake/sludge volumes. The 241-C-106 VOC source term also was prorated based on the ratio of the tank headspace for 241-C-106 versus the tank headspace for the other noncomplexed waste tank.

Extensive VOC sample data are available for Tank 241-SY-101, both in the vapor space and in the retained gas. As this was the most complete data for complexant concentrate waste, other tanks of complexant concentrate that had no data were prorated from 241-SY-101. The VOC source term for 241-SY-101 was multiplied by the ratio of the salt cake/sludge volumes of the 
other complexant concentrate tank tanks (241-AN-102, 241-AN-107, and 241-SY-103) divided by the 241-SY-101 salt cake/sludge volumes. The 241-SY-101 VOC source term also was prorated based on the ratio of the tank headspace for 241-SY-101 versus the tank headspace for the other complexant concentrate tank.

\subsection{AMMONIA METHODOLOGY}

The methodology used to estimate maximum concentration for ammonia in the DST vapor space was the same as that used for the flammable gases projections (ammonia, hydrogen, and methane) for saltwell pumping of SSTs to double-contained receiver tanks (Methodology for Predicting Flammable Gas Mixtures in Double-Contained Receiver Tanks, RPP-4941). This approximation is reasonable because the waste chemistry is similar and physical handling of the waste (pumping into a receiver tank through a riser) is comparable. The approach addresses the period during and after the filling of the receiving tank because, unlike the VOC source term, the worst-case ammonia source term is in the receiver tank. The Henry's Law constants, which are calculated based on several empirical models for the solubility of gases in liquid salt mixtures, are used to predict the amount of ammonia gas that would be released into the DST vapor space.

Because ammonia is a soluble gas, it is not reasonable to assume that $100 \%$ of the ammonia is released. A dynamic model (RPP-4941) was used to represent the higher ventilation rates in DSTs. This model takes credit for mass transfer limiting phenomena for the transfer of ammonia from the liquid to the gaseous phase of the vapor space. This also takes into account the fact that ammonia release is a surface-controlled phenomenon.

\subsection{AEROSOL METHODOLOGY}

An aerosol mass loading source term was estimated using methods and equations described in a variety of sources (An Engineering Assessment of the Aerosol and Vapor Flammability in 241-C-103, WHC-SD-WM-ER-181; Aerosol Technology/Properties, Behavior, and Measurement of Airborne Particles, Hinds 1982; Absorption of Sulfur Dioxide by Growing and Evaporating Water Droplets, Master's Thesis, Huckaby 1986; Aerosol Characteristics in the Offgas from a Pilot Scale Sluicing Operation, PNNL-10185). Aerosol particle size distribution was estimated by comparison with natural phenomena. 


\section{RPP-6023 REV 0}

This page intentionally left blank.

RPP-6023.doc 


\subsection{ASSUMPTIONS}

A number of simplifying assumptions had to be made to complete this study. Important assumptions are listed below along with the basis for the assumption. More detailed assumptions are documented as part of the spreadsheet.

The approach used to derive a source term was discussed with a process engineering statistician. Because the data contained in this assessment is a mix of qualitative and quantitative data, it is not possible to provide statistical measures of uncertainty. For this reason, elements of conservatism were enacted to bound the data as a measure of uncertainty. For VOC concentrations, the value used to calculate a source term was the measurement data plus one times the reported standard deviation. Where standard deviation data are not available, the concentration was increased by $30 \%$. For tentatively identified compounds the concentration was increased by a factor of two. For retained gas, the volume used for developing the source term was the reported value plus one times the standard deviation. Where there were retained gas volumes from two references, the higher volume was used. As additional data become available, increased precision and refinements in the data will bring about the ability to provide statistical measures of uncertainty. Until this happens the results should be used only within confines of the stated assumptions.

1. Retained gas is released instantaneously and is distributed throughout the headspace.

Basis: This is a conservative assumption. Retained gas will be released over a large area as the mixer pumps are started. The gas will rise into the headspace and be diluted before it reaches the tank HVAC exhaust stream that sweeps across the top of the tank. The VOC concentrations will gradually increase, but by the time maximum concentration is reached, some of the VOC already will have been swept from the tank, reducing the maximum concentration from the peak which would have been reached if the gas were instantaneously mixed throughout the headspace.

2. Except for the SY farm, tanks on an HVAC header are ventilated at the same rate. When the exhaust from a tank enters the header, the ventilation from the other tanks instantly dilutes the exhaust gas.

Basis: In the SY farm, 241-SY-101 is ventilated at a rate of $14.2 \mathrm{~m}^{3} / \mathrm{min}\left(500 \mathrm{ft}^{3} / \mathrm{min}\right)$, whereas the other two tanks are ventilated at a rate of $5.7 \mathrm{~m}^{3} / \mathrm{min}\left(200 \mathrm{ft}^{3} / \mathrm{min}\right)$ each. This is because 241-SY-101 is the worst-case flammable gas tank on Site. Other tank farms do not have a comparable situation.

3. Only one tank in a farm is being retrieved or transferred at a time.

Basis: The transfer files from HNF-SD-WM-SP-012 (Case 3S6D), were reviewed to determine if multiple tanks are operated in a tank farm simultaneously (see Appendix A). Ignoring the times where only a one- or two-day overlap occurred, there were 14 occurrences of simultaneous tank transfers into and/or out of one tank farm during a 20 -year period. On five occasions, two tanks in one farm were source tanks requiring simultaneous mixer pump operation. This could affect the VOC emissions. On five 
different occasions, two tanks in one farm were receiver tanks that could affect ammonia emissions. Considering how infrequent the dual operations were during a 20-year period, it is a reasonable assumption that for the source term study, only one tank in a farm is being retrieved or transferred at a time. In addition, the electrical distribution system is currently not capable of supporting concurrent operation of two sets of mixer pumps in the same farm. Ongoing projects will not change this situation. In fact, ongoing projects plan on supplying a single mixer pump variable speed drive (VSD) per farm and switches to operate one set of mixer pumps at a time.

4. One half of the waste from 241-SY-101 will be transferred to 241-SY-102 and then transferred to AP farm.

Basis: This is the current situation.

5. Mixer pump operation will not instigate a gas release event (GRE).

Basis: Mixer pumps are equipped with VSDs and will be started up at slow speed. The pumps will be ramped up gradually to normal operating speed. This was done successfully at 241-SY-101. The mixer pump will be operated periodically to prevent gas buildup and to exercise the pump seals. Testing at 241-AZ-101 will provide information about gas evolution rate that will be fed back to the operating procedures.

6. Fraction of retained gas released during mixer pumping is 0.06 .

Basis: Mixer pump operation will be controlled to limit gas release at any one time to $6 \%$ of the worst-case gas retention volume. The empirical mixer pump operation gas release fraction was developed based on three sources: (1) determinations of Tank 241-SY-101 mixer pump operational information, (2) 1995 mixer pump surrogate testing, and (3) preliminary hydrogen emission information on the Tank 241-AZ-101 mixer pump "bump." Tank 241-SY-101 data on mixer pump operation were used to estimate fraction of gas released. During the January 25, 2000, 241-SY-101 mixer pump operation, the ammonia concentration reached $320 \mathrm{p} / \mathrm{m}$ vol. Because the $241-\mathrm{SY}-101$ mixer pump is only $112 \mathrm{~kW}(150 \mathrm{hp})$, the $320-\mathrm{p} / \mathrm{m}$ vol value was increased by the ratio of $600 / 150$ to represent dual $224 \mathrm{~kW}(300 \mathrm{hp})$ mixer pumps. The ammonia concentration would then be $1280 \mathrm{p} / \mathrm{m}$ vol. This concentration would be reached in $241-S Y-101$ headspace if 2 percent of the retained gas were released. Preliminary hydrogen emission information was taken during the Tank 241-AZ-101 mixer pump test "bump" conducted on January 5, 2000. The hydrogen concentrations in the headspace of $241-A Z-101$ would have been reached if approximately 1 percent of the retained gas were released. When additional testing is conducted during the Tank 241-AZ-101 mixer pump test, the results can be used to refine the projected gas releases. The surrogate mixer pump testing conducted in 1995 by PNNL provided some preliminary information as to retained gas dispersion. These estimates were in the 2-5 percent range. Based on this information, a conservative 6 percent release was used for other tanks to estimate headspace concentrations. As a comparison, 241-SY-101 gas release events released 10 to 20 percent of the retained gas (Evaluation of August 1991 Tank 241-SY-101 Gas Release Event, WHC-SD-WM-PE-045). Mixer pumps will be started up in such a way that a significant gas release event is not initiated. Most of the retained gas will be evolved during mixer 
pump operation, but the peak concentration will occur when the mixer pumps are first started and $6 \%$ of the worst-case gas retention volume is released.

7. Similar waste types have similar VOC source terms.

Basis: Tanks containing complexant concentrate waste will have high organic content. The chemical and radiolytic reactions that generate VOC from the organic content in complexant concentrate waste should be similar for complexant concentrate tanks. The complexant concentrate tank with the worst VOC source term in the group of tanks studied (241-C-104) can be used to estimate VOC source term for complexant concentrate tanks that do not have data, including DSTs. This will be a conservative assumption. This same logic was applied to other waste types.

8. Fraction of gas released during LAW decanting is C.15.

Basis: Study \#TWS99.44, Rev. 1 "Potential for Inducing Gas Releases in Double-shell Tanks During Retrieval," done in August 1999 indicated a nominal 15\% of the retained gas could be released at one time by decanting the supernate from selected LAW tanks (specifically 241-AN-103, $-104,-105$, and 241-AW-101). 


\section{RPP-6023 REV 0}

This page intentionally left blank. 


\subsection{VOLATILE ORGANIC COMPOUNDS SOURCE TERM}

This section describes the origin of VOC in the tank headspace and the sources of data used. It also provides an estimate of the VOC source term.

\subsection{ORIGIN OF VOLATILE ORGANIC COMPOUNDS}

Volatile organic compounds in a tank's headspace derive from the organic compounds contained in the tank waste. The organic compounds in the tank waste produce VOC in the tank headspace by evaporation, hydrolysis, and radiochemical conversion. Some of the VOCs produced are partially soluble and are retained in the tank supernate. Observations from 241-C-106 indicate that partially water-soluble compounds are transported more efficiently from the sludge to the dome space than the water-insoluble substances such as paraffins. This means that the dome space concentration of partially water-soluble VOC compounds will increase as much as the water-insoluble compounds when waste disturbing operations occur. The slow rate of VOC generation by hydrolysis and radioloysis combined with the capacity of the waste solids to retain gases and organic compounds produces a metastable mixture that will be disrupted when the tank is retrieved. The VOC concentration in the headspace of the tank caused by gas released from the waste during retrieval and transfer is a much larger source than the concentration from steady state VOC evolution. Much more information on VOC origin is contained in Origins of Volatile Organic Compounds Emerging from Tank 241-C-106 During Sluicing, HNF-4261.

\subsection{DATA SOURCE FOR VOLATILE ORGANIC COMPOUNDS}

Data used to develop a non-radioactive chemical source term came primarily from the Tank Waste Information Network System (TWINS), 241-C-106 sluicing source term data, and retained gas measurements as described below. Tanks with dome space speciation data are listed in Table 5-1.

\subsubsection{Tank Waste Information Network System}

The TWINS contains substantial information about tank inventory, total organic carbon, and vapor space concentrations of ammonia and VOCs. Waste inventory for the tanks listed in Table 2-1 are contained in Table 5-1.

The TWINS estimates represent the best possible estimates of the tank contents and they are used consistently throughout the Hanford technical community. In addition, end-users of the TWINS data often need uncertainty estimates to support safety analyses, risk assessments, process designs, and other efforts. To verify this, PNNL developed and tabulated estimates of the empirical probability distributions of the Hanford defined waste tank inventories to allow investigators to make uncertainty statements for the standard inventory estimates. Probability distributions were estimated. For this source term study, concentration values for each of the VOC constituents were increased by one times the standard deviation listed in the TWINS. 
RPP-6023 REV 0

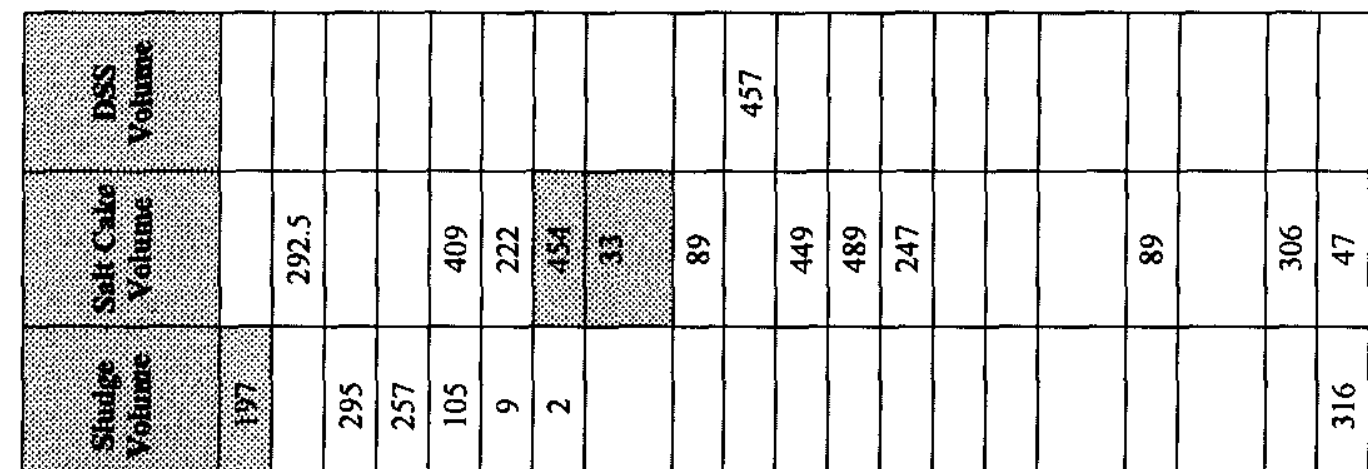

: 0.

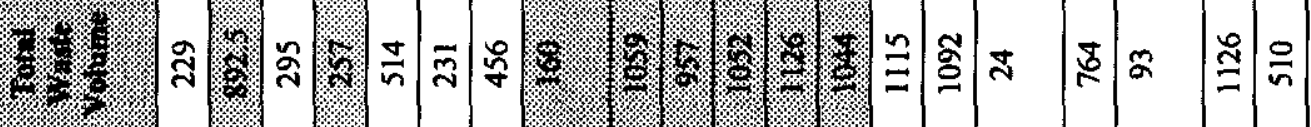

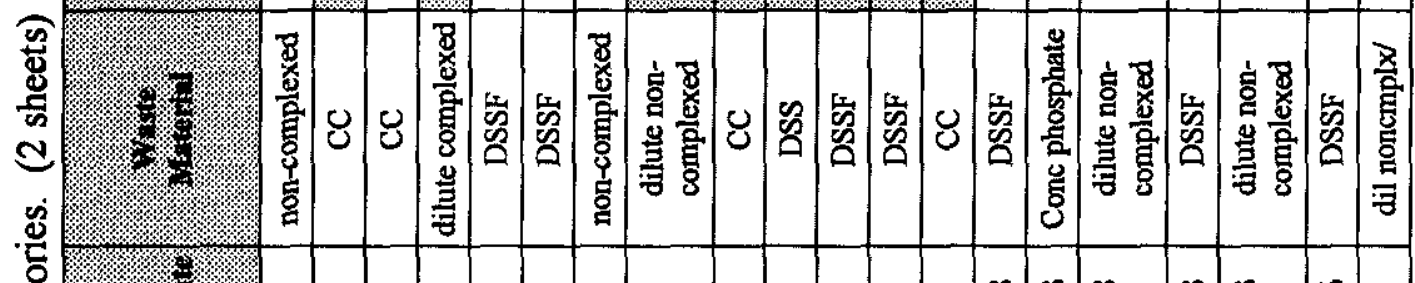

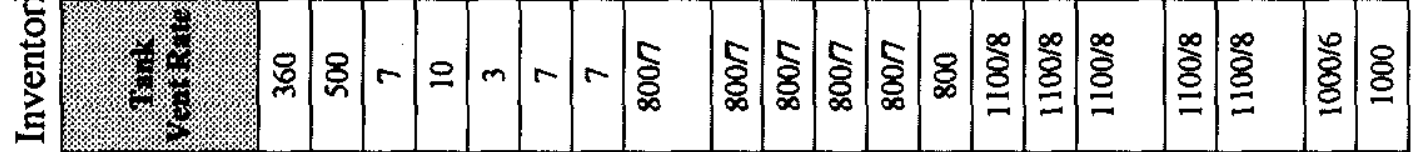
章

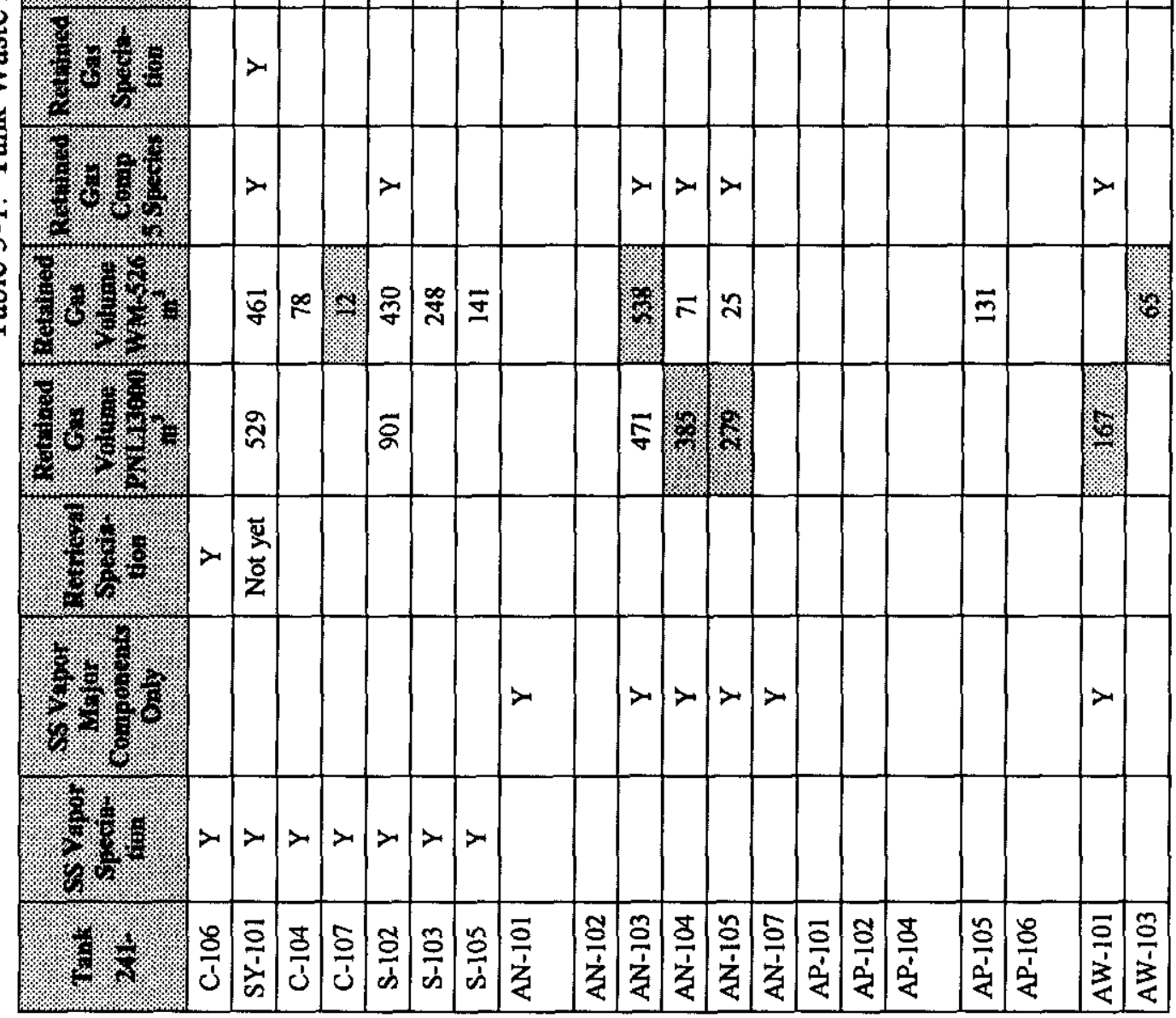


RPP-6023 REV 0

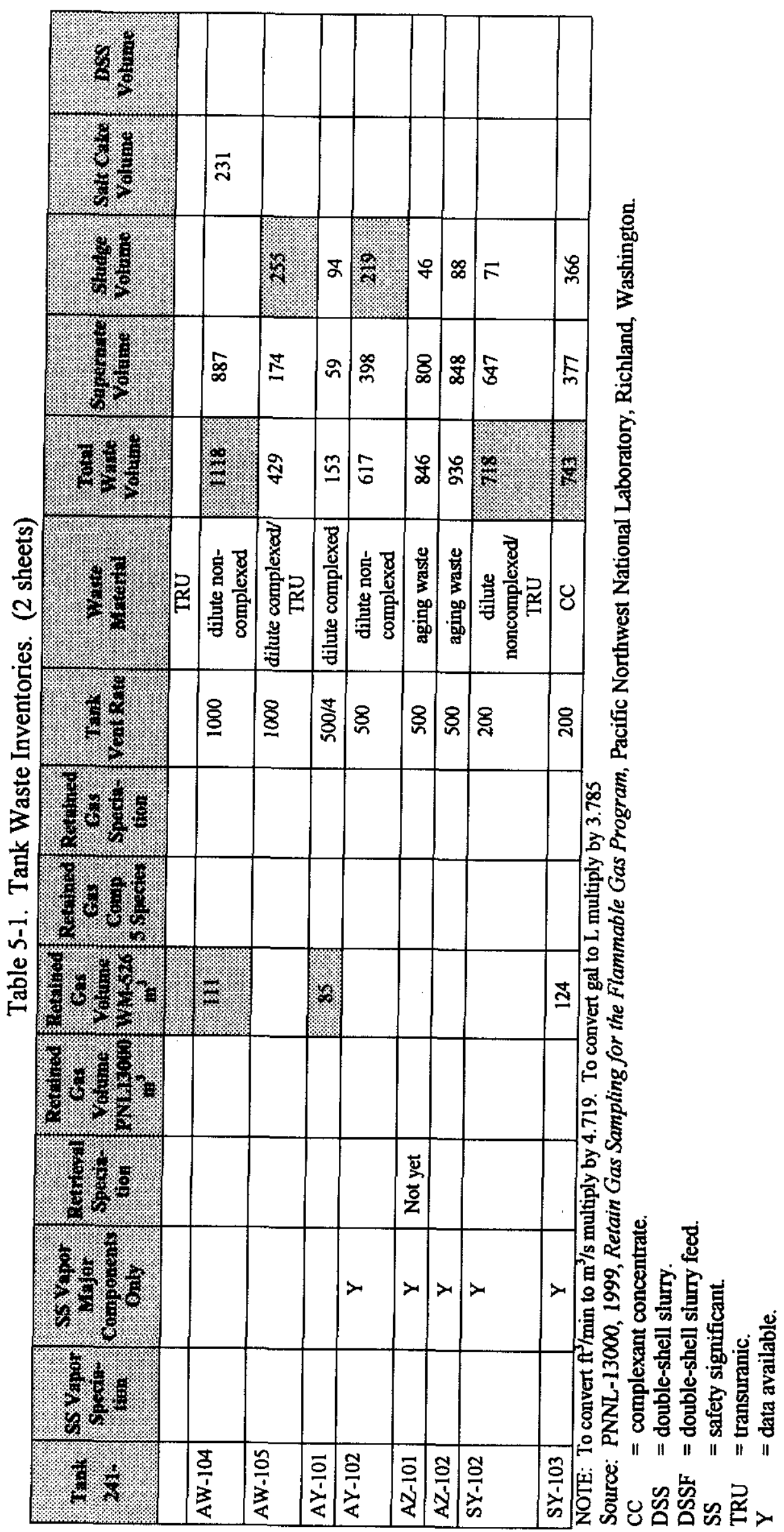




\subsubsection{1-C-106 Source Term Data}

Significant work has been done on the VOC source term during sluicing of 241-C-106 both before sluicing and during sluicing (HNF-4261). Based on these sampling events, it has been established that many different organic compounds were at low concentration in the dome space of the tank years before beginning sluicing. Acetone, butanol, heptenes, and heptanones were more abundant than the other organic compounds that included alkanes, alkenes, alcohols, aldehydes, ketones, and nitriles.

Six samples were collected from the ventilation stack of Tank 241-C-106 before the initiation of sluicing operations on December 16, 1998, and March 7, 1999. These samples also contained many different organic compounds including the same alkanes, alkenes, alcohols, aldehydes, ketones, and nitriles observed in the work from previous years. The concentrations of many of these substances did not exceed $5 \mathrm{p} / \mathrm{b}$ before sluicing and several of them were detected in only one of the six samples.

Samples that were opportunistically collected from the ventilation stack of Tank 241-C-106 during sluicing operations on November 18, 1998, contained hexane, heptane, 3-methylheptane, nonane, decane, undecane, dodecane, butylcyclopropane, 1-butyl-2-methylcyclopropane, 1-hexene, 2- and 3-heptene, several isomeric methylheptenes, and 3- and 4-heptanone (Chemical Analysis of Air Samples Collected on November 18, 1998 during Sluicing Activities at Tank 241-C-106, Huckaby and Evans 1999).

During sluicing, approximately 25 samples were collected from the ventilation stack of Tank 241-C-106 on December 16, 1998. These samples were analyzed at PNNL (Huckaby and Evans 1999) and at Special Analytic Support (SAS) (Tank Vapor Sampling and Data Analysis Package for Tank 241-C-106 Waste Retrieval Sluicing System Process Test Phase I, Sampled December 16, 1998, HNF-3949). Samples collected during sluicing operations on March 7, 1999, were analyzed at SAS (Tank Vapor Sampling and Data Analysis Package for

Tank 241-C-106 Waste Retrieval Sluicing System Process Test Phase II, Sampled March 7, 1999 HNF-4440). Another 10 samples, which were collected on March 28, 1999, were analyzed at SAS (Tank Vapor Sampling and Analysis Data Package for Tank 241-C-106 Waste Retrieval Sluicing System Process Test Phase III, Sampled March 28, 1999, HNF-4598).

The extensive results assembled in the data packages show that the observations reported by PNNL and by SAS for the triple sorbent tubes and SUMMA ${ }^{\text {TM }}$ canisters, which were collected at about the same time on December 16, 1998, were similar. The results for the triple sorbent tubes and SUMMA ${ }^{\mathrm{TM}}$ canisters collected at about the same time on March 7 and March 28, 1999, were also quite similar.

Three samples collected in SUMMA ${ }^{\mathrm{TM}}$ canisters during active sluicing operations on December 16, 1998; March 7, 1999; and March 28, 1999, were examined thoroughly. Pure compounds were used to resolve uncertainties about the identification of isomeric compounds, for example, by specifically comparing the chromatographic signals of pure E- and Z-2-heptene, E- and Z-3-heptene, and distinguishing between alkadienes and cycloalkenes. The identities of

SUMMA $^{\mathrm{n}}$ is a trademark of Moletrics, Inc., Cleveland, Ohio.

RPP-6023.doc 
about 40 tentatively identified compounds were affirmed by comparison of the retention times and mass spectra of the observed constituents with the retention times and mass spectra of pure compounds. The identities of these 40 compounds and 50 target compounds are therefore assured. About 70 other compounds were tentatively identified. Their organic structures were elaborated by comparison of their retention times and mass spectra with information obtained by the study of the target analytes and reference compounds as well as with information in the chemical literature, by comparison with related results provided by PNNL, Oak Ridge National Laboratory (ORNL), and Oregon Graduate Institute (OGI), and by chemical inferences based on the original organic source term. Most of these identifications are secure, but some of the positional and geometric isomers of the alkylcyclohexanes, for example, are not assured. In some cases, substances are listed as unknown. Most of the substances in this category were present in low abundance or coeluted and their identification was hindered by their low concentrations and often by poorly defined mass spectrum. The uncertainty in the concentration of a target compound is about 30 percent (Headspace Gas and Vapor Characterization Summary for the 43 Vapor Program Suspect Tanks, WHC-SD-WM-ER-514; Comparison of Vapor Sampling System (VSS) and In Situ Vapor Sampling Methods on Tank C-107, BY-108, and $S-102$, PNNL-11186). The concentration of tentatively identified compounds is measured by comparison of the observed ion concentration current with the ion current of an internal standard (HNF-4261). Experience suggests that these concentrations are established within a factor of 2.

When sluicing began, there was an immediate large increase in the VOC concentration in the stack. The concentration change depended on the intensity of the sluicing operation. Results for the three sluicing operations were similar in the sense that the concentrations of water-insoluble organic compounds out the stack increased to a greater extent than the water-soluble compounds. To illustrate, most water-soluble compounds that were present at concentrations greater than $5 \mathrm{p} / \mathrm{b}$ (including alcohols and ethers such as butanol and 1,3-diethyl-1, 4-epoxybutane; aldehydes and ketones such as butanal and 3-heptanone; and nitriles such as propanenitrile) increased several fold during active sluicing. The concentrations of the water-insoluble compounds (such as heptane and the other alkanes, the alkenes such as the heptenes, and ketones such as heptanones) increased by much larger amounts. These observations imply that water-soluble organic compounds generated in the sludge were being transported more efficiently, presumably through the aqueous supernatant layer, to the dome space than water-insoluble compounds.

Disturbance of the waste by sluicing led to a disproportionately large increase in the concentrations of the less volatile and less mobile compounds in the ventilation stack.

Essentially the same array of compounds was detected in each operation. However, the concentrations of organic compounds in the ventilation stack varied considerably. The sum of the concentrations of the compounds in the SUMMA ${ }^{\mathrm{TM}}$ canisters collected during active sluicing were approximately $20 \mathrm{p} / \mathrm{m}\left(160 \mathrm{mg} / \mathrm{m}^{3}\right)$ on December 16,$1998 ; 400 \mathrm{p} / \mathrm{m}\left(1,800 \mathrm{mg} / \mathrm{m}^{3}\right)$ on March 7, 1999; and $100 \mathrm{p} / \mathrm{m}\left(424 \mathrm{mg} / \mathrm{m}^{3}\right)$ on March 28, 1999.

The organic compounds emerging from the ventilation stack during sluicing operations were derived from the phosphate esters and normal paraffinic hydrocarbons originally used for ${ }^{90} \mathrm{Sr}$ removal operations in B Plant. The composition of the original mixture was altered by evaporation of hydrocarbons, hydrolysis of tributyl phosphate, and radiochemical conversions of hydrocarbons and phosphate esters. Sodium bis(2-ethylhexyl)phosphate, the least volatile and least reactive compound in the original mixture was deemed responsible for the relatively high abundance of compounds having seven and eight carbon atoms in the VOC. The inherently slow 
rate of hydrolysis of this molecule coupled with its insolubility in water and its very low vapor pressures led to the selective retention of this molecule. Its slow radiolytic decomposition, coupled with the capacity of the sludge to retain gases and organic compounds, produced a metastable mixture that was disrupted when the sluicing operations were undertaken.

\subsubsection{Retained Gas Measurements}

Composition and quantities of retained gas have been measured for selected flammable gas tanks (Composition and Quantities of Retained Gas Measured in Hanford Waste Tanks 241-AW-101, $A-101, A N-105, A N-104$, and AN-103, PNNL-11450; and Retain Sampling Results for the Flammable Waste Program, PNNL-13000. Tank samples were obtained with the RGS, which is a modified version of the universal core sampler used to core-sample Hanford tanks. The RGS is designed specifically for use with the gas extraction equipment in a hot cell to capture and extrude a gas-containing waste sample in a hermetically sealed system. The retained gases were then extracted and stored in a small gas canister. The composition of the gases obtained in the canisters was measured by mass spectroscopy. The total gas volume in the sample was obtained from analyzing pressure, volume, and temperature from the extraction process.

The RGS method provided retained gas volume fraction measurements with low uncertainty (PNNL-13000). The uncertainty caused by gas solubility and extraction measurement uncertainty was usually less than \pm 15 percent of the measurement for samples from nonconvective waste. There was typically good agreement between RGS and void fraction instrument data, validating the low calculated uncertainty.

For this source term study, retained gas volumes were increased by two times the standard deviation listed in the RGS study. Where retained gas volumes were available from two sources, the highest value was used.

\subsection{ESTIMATED VOLATILE ORGANIC COMPOUND SOURCE TERM}

The source term for COCs and for total organics is contained in Table 5-2. Column 4 is the SQER from WAC-173-460-150 in $\mathrm{lb} / \mathrm{h}$ or $\mathrm{lb} / \mathrm{yr}$, depending upon toxic air pollution (TAP) classification. Column 7 is compared to column 4. Column 5 is the TAP ASIL from WAC-173-460. Column 8 is compared to column 5 . 


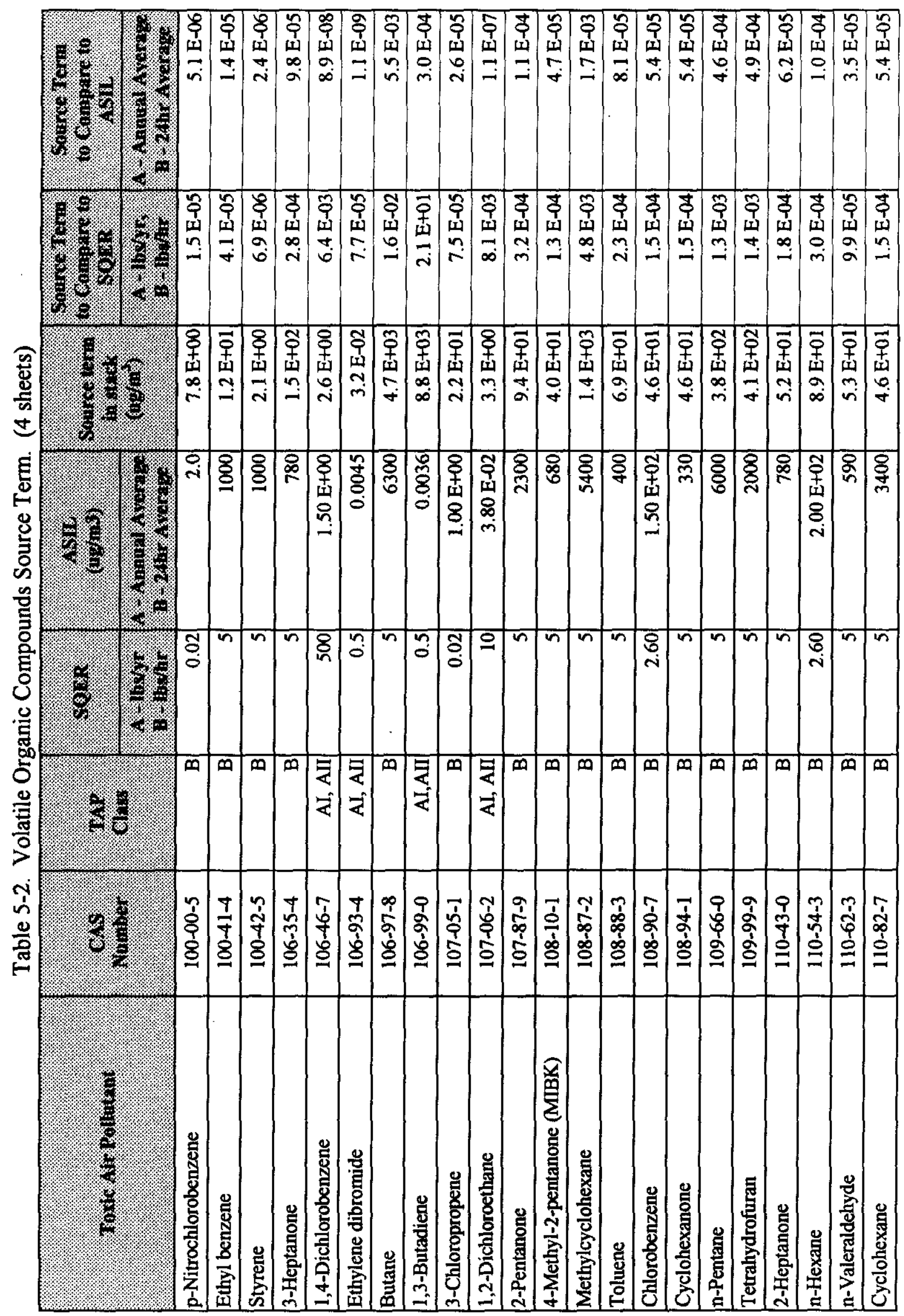




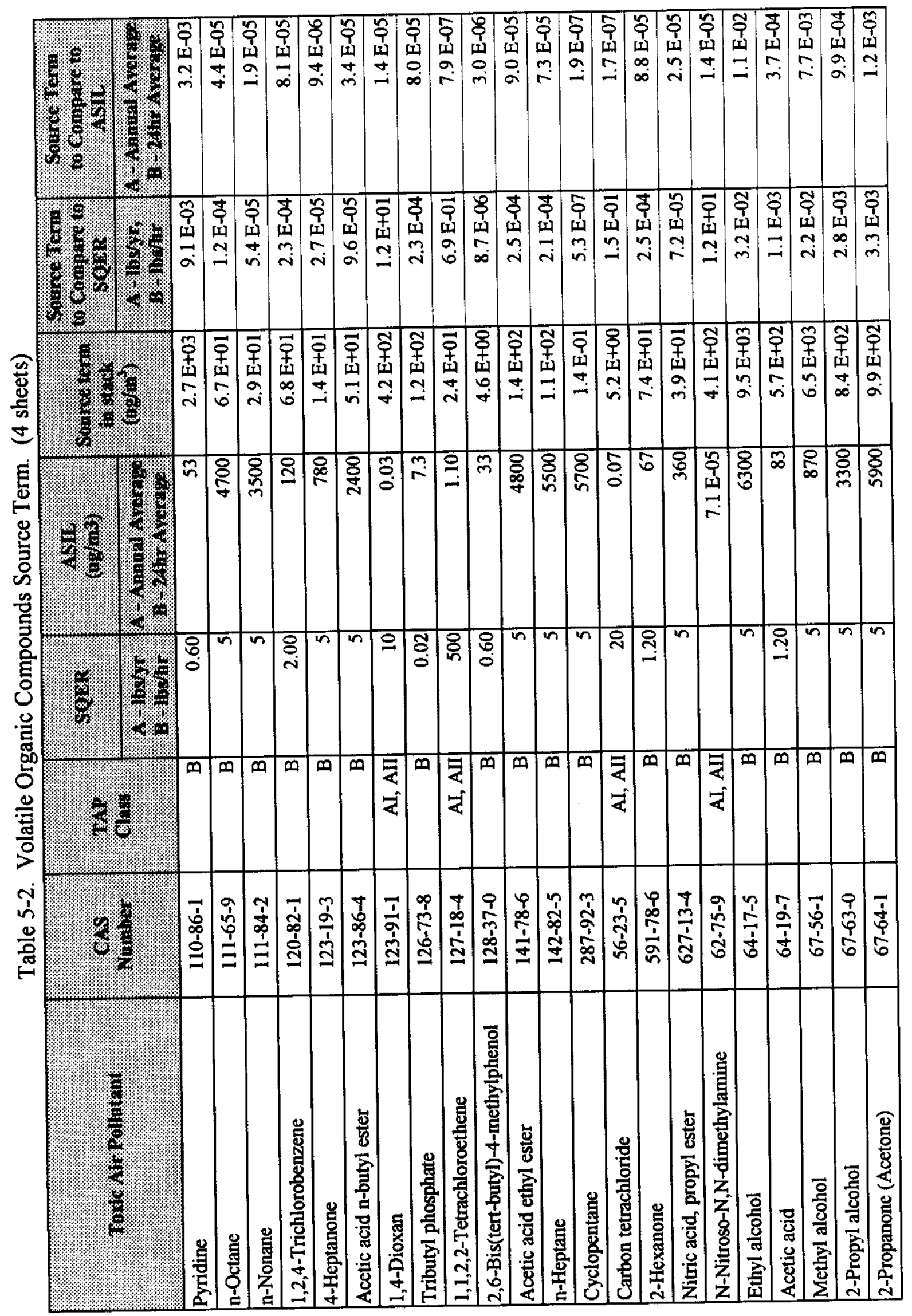


RPP-6023 REV 0

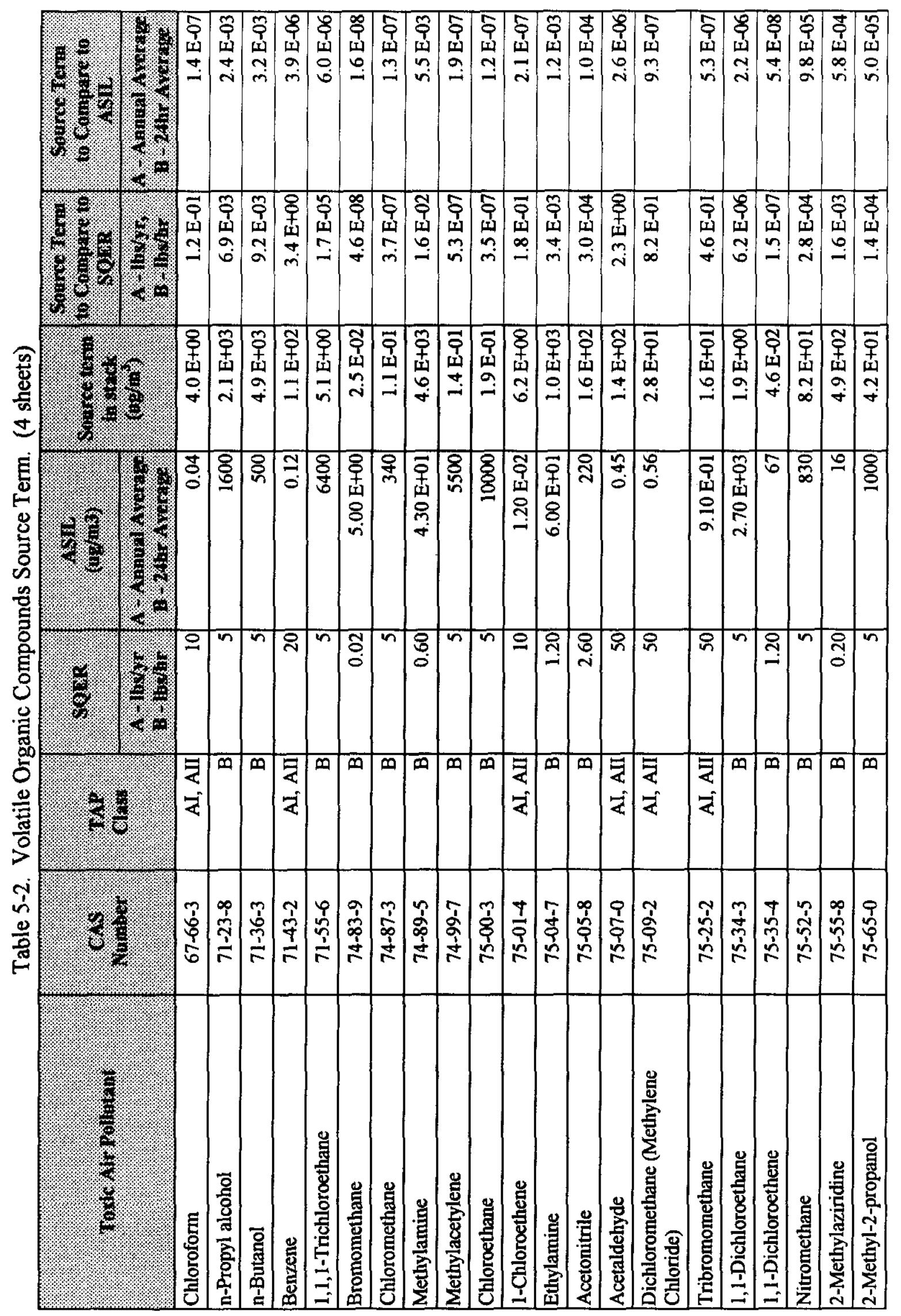


RPP-6023 REV 0

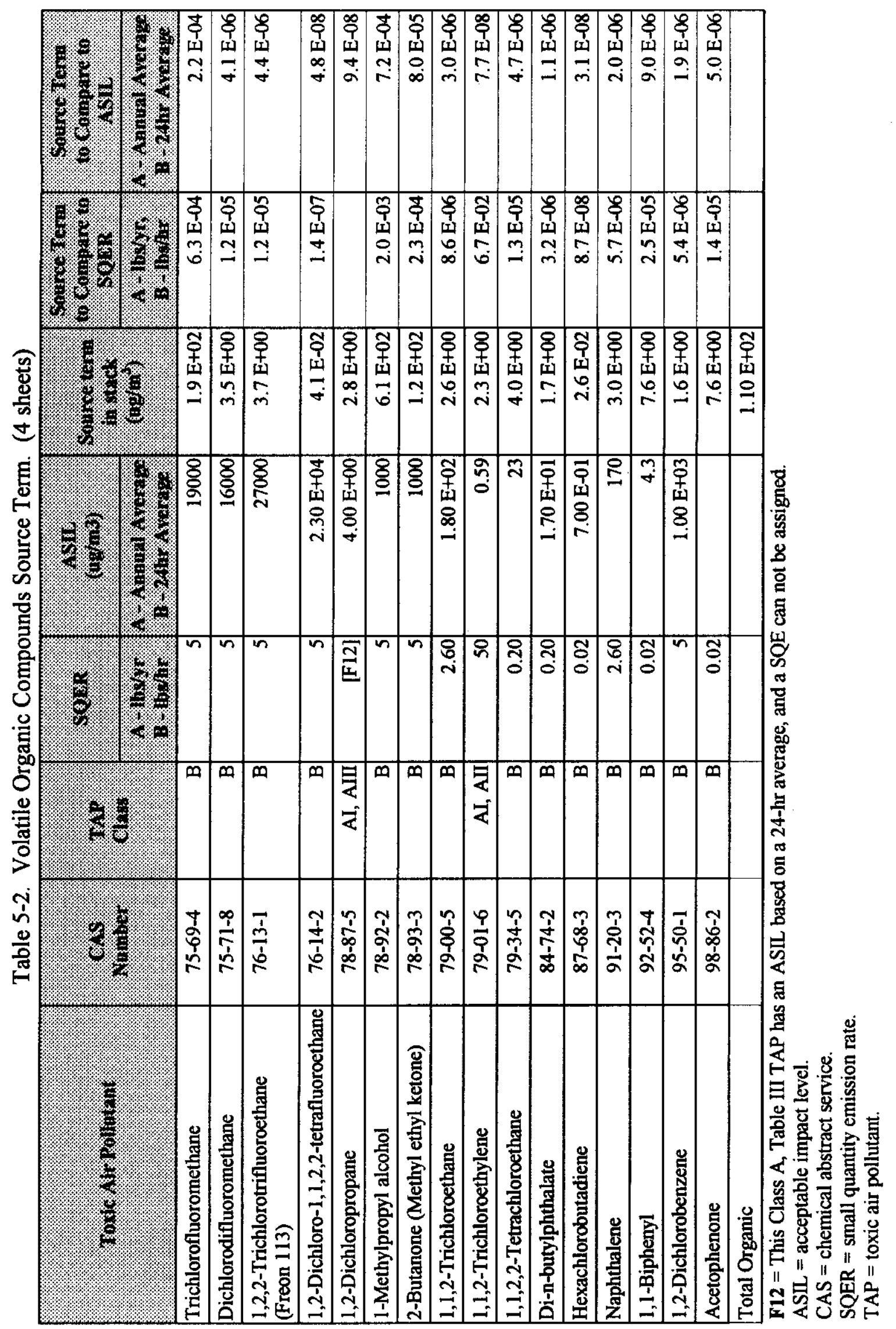




\subsection{AEROSOL SOURCE TERM}

Waste transferred during retrieval operations will be liquid or solid-liquid slurry transported by way of pipelines. Various DSTs will serve as the receiver tanks, and the waste will be introduced either by falling through the headspace to the waste surface or directly into the receiver tank waste by way of a drop leg. The first method offers the advantages of lower cost and simplicity, and avoids the waste siphoning issues associated with a drop leg. The disadvantage is the direct waste-air contact, which may result in significant gas (particularly ammonia) release and may promote aerosol generation through mechanical dispersion and condensation. The advantages and disadvantages of the drop leg are essentially the reverse of the first.

This analysis estimates aerosol concentrations on the order of $0.01 \mathrm{~g} / \mathrm{m}^{3}$ that may be generated in DST headspaces during waste retrieval with both types of configuration.

\subsection{AN AEROSOL PRIMER}

Appendix D is a partial reprint of Appendix A "An Aerosol Primer," from WHC-SD-WM-ER-181.

\subsection{AEROSOL SIZE DISTRIBUTION}

Condensation aerosols form when water saturated air subcools in the presence of nucleation sites. Such aerosols form clouds and fogs, and have, in general, smaller droplet size distributions (usually $<30 \mu \mathrm{m}$ ) than mechanically generated aerosols. It can be estimated that a typical condensation aerosol that might form in a tank headspace would possess a mass concentration of about $10 \mathrm{mg} / \mathrm{m}^{-3}$.

Mechanical aerosol generation occurs when the kinetic energy of a moving material is converted to overcome the surface tension of the liquid, increasing the liquid surface area. Particulate Technology (Orr 1966) provides criteria for estimating the maximum droplet diameter that can resist secondary break-up when the droplet is moving through air with relative velocity $\mathrm{v}$ (as in a pipe discharging directly into a tank headspace):

$$
\mathrm{D}=\left(\frac{16 \sigma}{\rho_{\mathrm{g}} \mathrm{v}^{2}}\right)
$$

Where,

$\mathrm{D}=$ maximum droplet diameter that can resist break-up

$\mathrm{v}=$ relative velocity between liquid and air

$\sigma=$ surface tension of liquid (water)

$\rho_{\mathrm{g}}=$ density of air 
For air at $25^{\circ} \mathrm{C}$ and water flow velocities over a range of about 0.91 to $9.14 \mathrm{~m} \mathrm{sec}$ ( 3 to $30 \mathrm{ft} \sec ^{-1}$ :

$$
\begin{aligned}
& \sigma=0.72 \text { dyne cm}^{-1}=0.072 \mathrm{~kg} \mathrm{sec}^{-2} \\
& \rho_{\mathrm{g}}=1.408 \mathrm{~kg} \mathrm{~m}^{-3}
\end{aligned}
$$

The results are shown in Figure 6-1.

Figure 6-1. Maximum Stable Water Droplet Diameter.

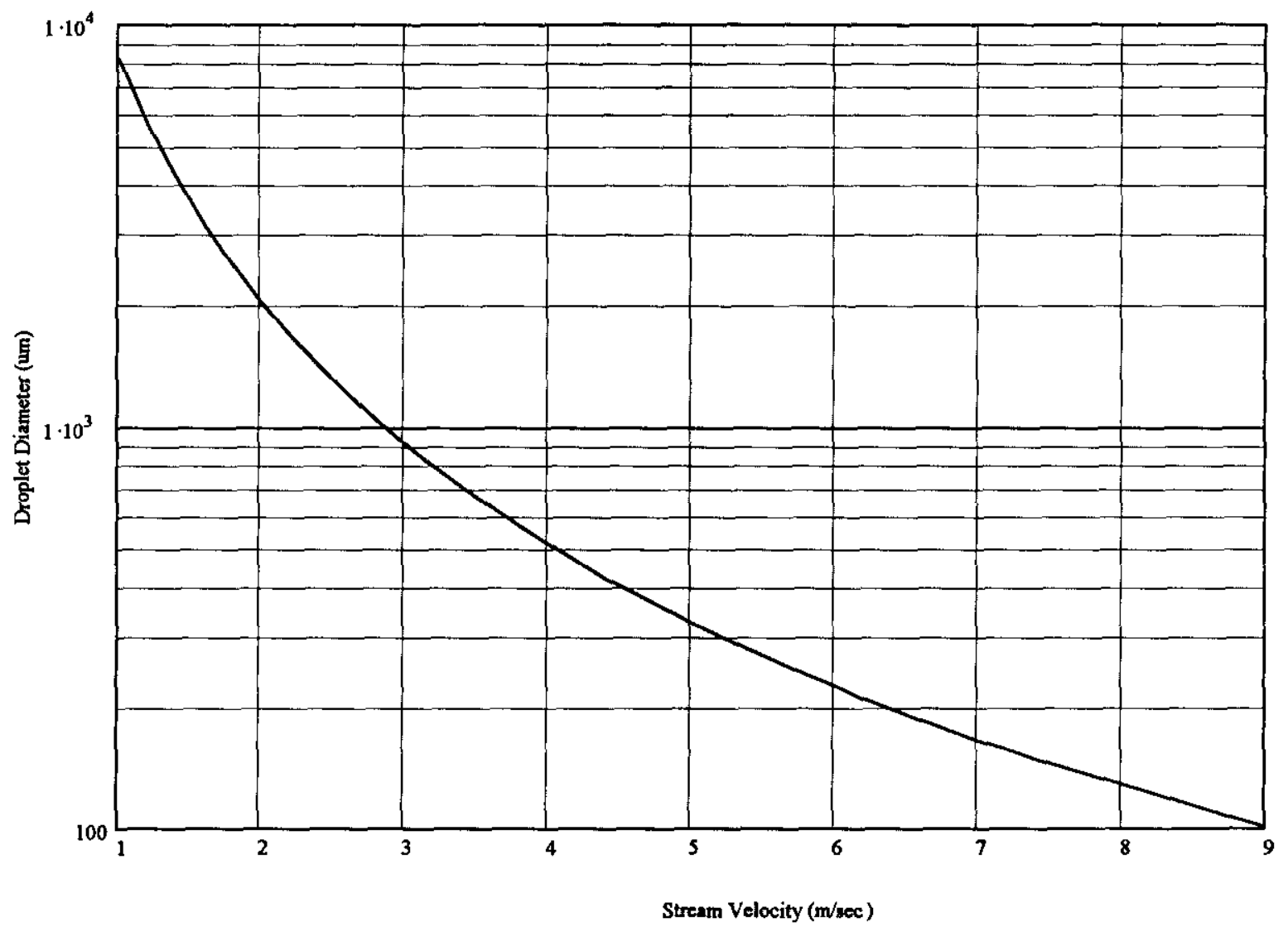

Therefore, this relation indicates a significant increase in the break up of secondary droplets with increasing flow velocity. One conclusion from Figure $6-1$ is that mechanically produced aerosols become finer, and thus are more likely to persist and create higher mass loadings, when more kinetic energy is available to overcome the surface tension of the water droplets. Therefore, reducing water spray velocities should reduce the mass loadings of any aerosol thus generated.

A survey of typical size distributions for various aerosol conditions is shown in Table 6-1. 
Table 6-1. Aerosol Size Distributions.

\begin{tabular}{|c|c|}
\hline 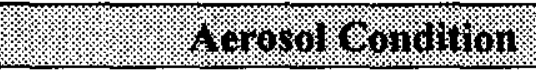 & 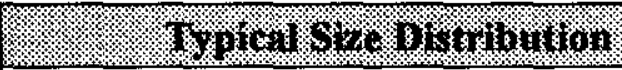 \\
\hline Clouds and fogs & $0.1 \mu \mathrm{m}$ to $100 \mu \mathrm{m}$ \\
\hline Mists & $0.01 \mu \mathrm{m}$ to $10 \mu \mathrm{m}$ \\
\hline Sprays & $10 \mu \mathrm{m}$ to $5000 \mu \mathrm{m}$ \\
\hline Rain & $>100 \mu \mathrm{m}$ \\
\hline
\end{tabular}

\subsection{AEROSOL MASS LOADINGS}

Extensive analysis and testing on mechanical aerosol generation was performed by PNNL in support of Project W-320 design activities (PNNL-10185). These studies indicated that the high nozzle discharge velocity of the sluicer could be expected to generate and maintain aerosol concentrations of about $0.330 \mathrm{~g} / \mathrm{m}^{3}$. Figure 6-2 shows a specialized mechanical aerosol generator claimed to be capable of producing an aerosol concentration of up to $50 \mathrm{~g} / \mathrm{m}^{3}$ at the outlet.

Figure 6-2. A Mechanical Aerosol Generator.

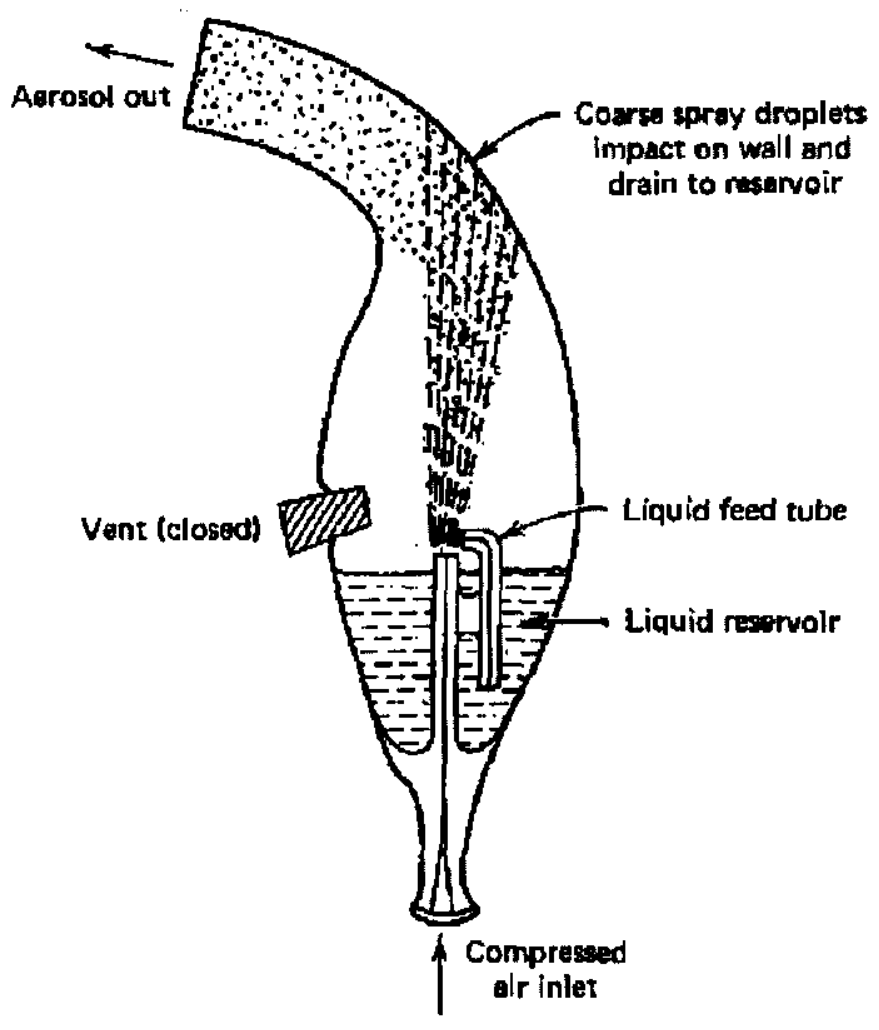




\section{RPP-6023 REV 0}

Figure 6-3 shows water vapor mass loading in saturated air at 100 percent relative humidity (RH).

Theoretically, if a volume of saturated air could be cooled immediately in the presence of sufficient nucleation sites, these data can be used to estimate limiting aerosol mass concentrations. For example, the cooling of saturated air from $24^{\circ} \mathrm{C}$ to $23{ }^{\circ} \mathrm{C}$ could, under ideal conditions, produce an aerosol concentration of $1.2 \mathrm{~g} / \mathrm{m}^{3}$.

Figure 6-3. Water Vapor Mass Loading at 100\% RH.

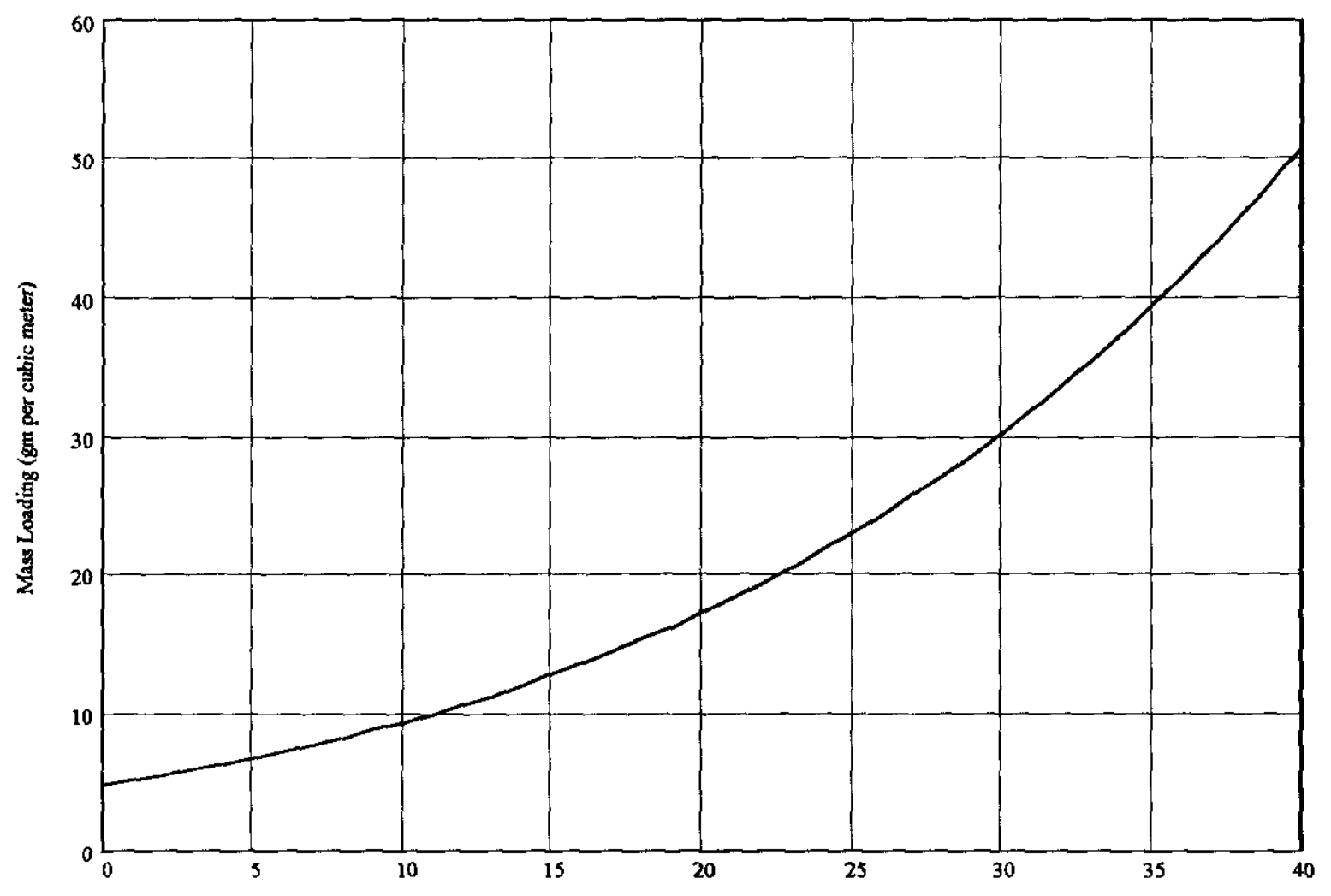

Temperature $\left({ }^{\circ} \mathrm{C}\right)$ 


\section{RPP-6023 REV 0}

The following calculations serve to illustrate that at typical waste transfer flow rates and realistic temperature differentials, sufficient energy could be present in the waste steams such that, when exposed to a tank atmosphere, significant amounts of water vapor (and potentially aerosol) loadings may be created. In practice, however, such theoretical water loadings in air are not seen.

If water is injected into a tank headspace at a higher temperature than the surrounding air, some water in the stream will evaporate to equilibrate the temperatures between the liquid and gas phases, seeking to satisfy the equation:

$$
\mathrm{m}_{\text {liquid }} \int \mathrm{CpdT}=\mathrm{m}_{\text {vapor }} \int \mathrm{dH} \quad \text { Such that } \quad \mathrm{m}_{\text {vapor }}=\mathrm{m}_{\text {liquid }} \frac{\int \mathrm{Cpd} T}{\int \mathrm{dH}}
$$

If the contact time were sufficiently long, the energy balance would be satisfied. Assuming a $227 \mathrm{~L} / \mathrm{min}(60 \mathrm{gal} / \mathrm{min})$ flow rate of $30^{\circ} \mathrm{C}$ water into $20^{\circ} \mathrm{C}$ air:

$$
\begin{aligned}
& \mathrm{m}_{\text {liquid }}=3.78 \mathrm{~kg} \mathrm{sec}^{-1} \\
& \int \mathrm{CpdT}=\left(4.18 \mathrm{~J} \mathrm{~kg}^{-1}{ }^{o} \mathrm{C}^{-1}\right)\left(10^{\circ} \mathrm{C}\right)=41.8 \mathrm{~J} \mathrm{~kg}^{-1} \\
& \int \mathrm{dH}=\left(\mathrm{H}_{\text {vapor }}-\mathrm{H}_{\text {liquid }}\right)=(2538.2-83.9) \times 10^{3} \mathrm{~J} \mathrm{~kg}^{-1} \\
& \mathrm{~m}_{\text {vapor }}=\left(3.78 \mathrm{~kg} \mathrm{sec}^{-1}\right)\left(41.8 \mathrm{~J} \mathrm{~kg}^{-1}\right)\left((2538.2-83.9) \times 10^{3} \mathrm{~J} \mathrm{~kg}^{-1}\right)^{-1}=0.0623 \mathrm{~kg} \mathrm{sec}^{-1}
\end{aligned}
$$

To change water-saturated air at $20^{\circ} \mathrm{C}$ to $30^{\circ} \mathrm{C}$ would require:

$$
(30.3-17.3) \mathrm{gm} \mathrm{m}^{-3}=0.0130 \mathrm{~kg} \mathrm{~m}^{-3}
$$

To change dry air at $20^{\circ} \mathrm{C}$ to water-saturated air at $30^{\circ} \mathrm{C}$ would require:

$$
(30.3-0.0) \mathrm{gm} \mathrm{m}^{-3}=0.0303 \mathrm{~kg} \mathrm{~m}^{-3}
$$

Comparing the water evaporation rate with the rate required by changing the vapor water mass of $20^{\circ} \mathrm{C}$ air at 100 percent $\mathrm{RH}$ to $30^{\circ} \mathrm{C}$ air at 100 percent $\mathrm{RH}$ :

$$
\frac{0.0623 \mathrm{~kg} / \mathrm{s}}{0.0130 \mathrm{~kg} / \mathrm{m}^{3}}=4.79 \mathrm{~m}^{3} \mathrm{~s}^{-1}=10200 \mathrm{ft}^{3} \mathrm{~min}^{-1}
$$

Or alternatively, for dry $20^{\circ} \mathrm{C}$ air to $30^{\circ} \mathrm{C}$ air at 100 percent $\mathrm{RH}$ :

$$
\frac{0.0623 \mathrm{~kg} / \mathrm{s}}{0.0303 \mathrm{~kg} / \mathrm{m}^{3}}=2.06 \mathrm{~m}^{3} \mathrm{~s}^{-1}=4360 \mathrm{ft}^{3} \mathrm{~min}^{-1}
$$


These hypothetical calculations indicate that at typical flow rates and realistic temperature differentials, sufficient energy could be present in the waste streams exposed to a tank atmosphere to create significant amounts of water vapor (and potentially aerosol) loadings.

\subsection{ESTIMATED AEROSOL SOURCE TERM}

Even though the previous section indicates the potential to generate significant concentrations of water in the atmosphere, particularly when waste is discharged directly to the tank headspace, the expected mass concentrations of any aerosols that may be generated in a DST headspace as a result of waste transfer are indicated to be small in relation to the typical mass concentrations of water vapor in ambient air. Mixing and other mass transfer limitations are probably major reasons why such extremes are not actually encountered. It should be noted that under more realistic conditions, condensation aerosol concentrations (Section 6-2) are more on the order of $0.01 \mathrm{~g} / \mathrm{m}^{3}$, strongly indicating the previous theoretical examples are not supported by observational evidence.

This can be further illustrated by estimating the terminal velocity of the individual droplets as predicted in Figure 6-1. The smallest droplet size is indicated as about $100 \mu \mathrm{m}$. Using the definition of the coefficient of drag $\left(C_{D}\right)$ and a plot of $C_{D}$ versus $R e$, an argument can be made that aerosols of this size will not be persistent in the tank headspace and will quickly settle out under the force of gravity:

$$
\mathrm{C}_{\mathrm{D}}=\frac{4}{3} \mathrm{gD}_{\mathrm{d}} \mathrm{v}_{\infty}\left(\frac{\rho_{\mathrm{d}}}{\rho_{\mathrm{c}}}-1\right) \quad \text { and } \quad \mathrm{Re}=\frac{\mathrm{D}_{\mathrm{d}} \mathrm{v}_{\infty}\left(\rho_{\mathrm{d}}-\rho_{\mathrm{c}}\right)}{\mu_{c}}
$$

Where

$$
\begin{aligned}
& \mathrm{v}_{\infty}=\text { terminal velocity of the dispersed phase (water droplet) }=\text { ? (TBD) } \\
& \mathrm{g}=9.81 \mathrm{~m} \mathrm{~s}^{-2} \\
& \mathrm{D}_{\mathrm{d}}=\text { diameter of dispersed phase (water droplet) }=1 * 10^{-4} \mathrm{~m} \\
& \rho_{d}=\text { density of the dispersed phase (water droplet) }=1000 \mathrm{~kg} \mathrm{~m}^{-3} \text { at } 20^{\circ} \mathrm{C} \\
& \rho_{\mathrm{c}}=\text { density of the continuous phase (air) }=1.21 \mathrm{~kg} \mathrm{~m}^{-3} \text { at } 20^{\circ} \mathrm{C} \\
& \mu_{c}=\text { dynamic viscosity of the continuous phase (air) }=1.81^{*} 10^{-5} \mathrm{~kg} \mathrm{~m}^{-1} \mathrm{~s}^{-1} \text { at } 20^{\circ} \mathrm{C}
\end{aligned}
$$

Using these equations and values, along with a standard $C_{D}$ versus $R e$ plot for spheres, gives:

$$
\begin{aligned}
& V_{\infty}=0.53 \mathrm{~m} \mathrm{~s}^{-1} \\
& \operatorname{Re}=3000 \\
& C_{D}=0.30
\end{aligned}
$$

This result indicates that the droplets predicted by Figure 6-1 will exist in a tank headspace at most for only a few seconds before settling out and could not build up or otherwise contribute to the aerosol concentration over any extended period.

Example atmospheric water mass loadings in air are shown in Table 6-2. 


\section{RPP-6023 REV 0}

Table 6-2. Water Mass Loading.

\begin{tabular}{|c|c|}
\hline 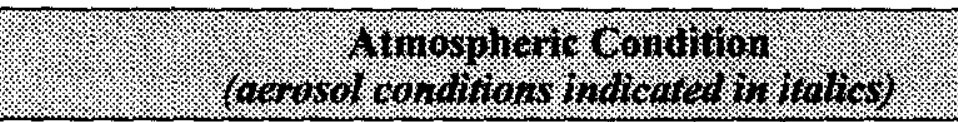 & 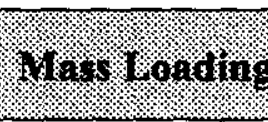 \\
\hline Typical atmospheric fog / clouds & $\sim 0.01 \mathrm{~g} / \mathrm{m}^{3}$ \\
\hline Tank 241-C-106 sluicer aerosol generation test results & $\sim 0.33 \mathrm{~g} / \mathrm{m}^{3}$ \\
\hline $0^{\circ} \mathrm{C}$ air at $100 \%$ relative humidity & $4.82 \mathrm{~g} / \mathrm{m}^{3}$ \\
\hline $30^{\circ} \mathrm{C}$ air at $100 \%$ relative humidity & $-30 \mathrm{~g} / \mathrm{m}^{3}$ \\
\hline Claimed performance of DeVilbiss Model 40 nebulizer & $\sim 50 \mathrm{~g} / \mathrm{m}^{3}$ \\
\hline $100^{\circ} \mathrm{C}$ air at $100 \%$ relative humidity & $800 \mathrm{~g} / \mathrm{m}^{3}$ \\
\hline
\end{tabular}

The baseline aerosol concentrations are estimated in Table 6-3.

The $0.33 \mathrm{~g} / \mathrm{L}$ mass loading from Table 6-3 was generated from a spray stream with a $43 \mathrm{~m} / \mathrm{s}$ $(140 \mathrm{ft} / \mathrm{s})$ velocity relative to the surrounding air. Therefore, a concentration expression can be theorized to be a function of the square of relative velocity and that it would predict a concentration of $0.01 \mathrm{~g} / \mathrm{L}$ at 0 velocity and $0.33 \mathrm{~g} / \mathrm{L}$ when a water stream is injected into a tank headspace at $43 \mathrm{~m} / \mathrm{s}(140 \mathrm{ft} / \mathrm{s})$ velocity. Mechanical aerosol generation occurs on conversion of kinetic energy to overcome the surface energy of water droplets to create larger numbers of smaller droplets (and increase their collective surface area).

Table 6-3. Estimated Double-Shell Tank Headspace Aerosol Concentrations.

\begin{tabular}{|c|c|}
\hline Oondition & 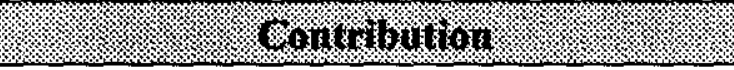 \\
\hline $\begin{array}{l}\text { Condensation (baseline) } \\
\text { This condition is equivalent to } \\
\text { subsurface introduction of a waste } \\
\text { stream into a DST via a dropleg. }\end{array}$ & $0.01 \mathrm{~g} / \mathrm{L}$ \\
\hline $\begin{array}{l}\text { Mechanical generation } \\
\text { This condition is equivalent to } \\
\text { introduction of waste stream } \\
\text { directly into a DST atmosphere. }\end{array}$ & $\begin{array}{c}0 \mathrm{~g} / \mathrm{L} \text { at } 0 \mathrm{~m} / \mathrm{s}(0 \mathrm{ft} / \mathrm{s}) \text { spray velocity } \\
\text { to } \\
0.33 \mathrm{~g} / \mathrm{L} \text { at } 43 \mathrm{~m} / \mathrm{s}(140 \mathrm{ft} / \mathrm{s}) \text { spray velocity }\end{array}$ \\
\hline
\end{tabular}

$\overline{\mathrm{DST}}=$ double-shell tank.

$$
\begin{aligned}
& \mathrm{v}_{\mathrm{ref}}=42.7 \mathrm{~m} / \mathrm{s}(140 \mathrm{ft} / \mathrm{s}) \\
& \text { mass loading }=0.01\left(1+33\left(\frac{\mathrm{v}}{\mathrm{v}_{\text {ref }}}\right)^{2}\right)\left(\frac{\text { grams }}{\mathrm{m}^{3}}\right)
\end{aligned}
$$

Liquid waste flow rates into the tank headspace do not factor in to this relation because the earlier examples suggest that any realistic waste flow rate into a DST atmosphere could easily possess the potential to change the water concentrations significantly in the headspace of a DST. 


\section{RPP-6023 REV 0}

For example, a waste that is introduced below a DST surface would not be expected to generate an aerosol. A waste stream introduced into the headspace of a DST at $2 \mathrm{~m} / \mathrm{s}\left(6 \mathrm{ft} / \mathrm{s}^{-1}\right)$ velocity would indicate an aerosol concentration of:

$$
\text { mass loading }=0.01\left(1+33\left(\frac{6}{140}\right)^{2}\right)\left(\frac{\text { grams }}{\mathrm{m}^{3}}\right)=0.0106\left(\frac{\text { grams }}{\mathrm{m}^{3}}\right)
$$

A plot of the estimated tank headspace aerosol loadings as a function of the velocity of the injection into the DST headspace is shown in Figure 6-4 (where subsurface injection is considered to produce a $0.01 \mathrm{~g} / \mathrm{m}^{-3}$ aerosol concentration). 


\section{RPP-6023 REV 0}

Figure 6-4. Water Aerosol Mass Loading.

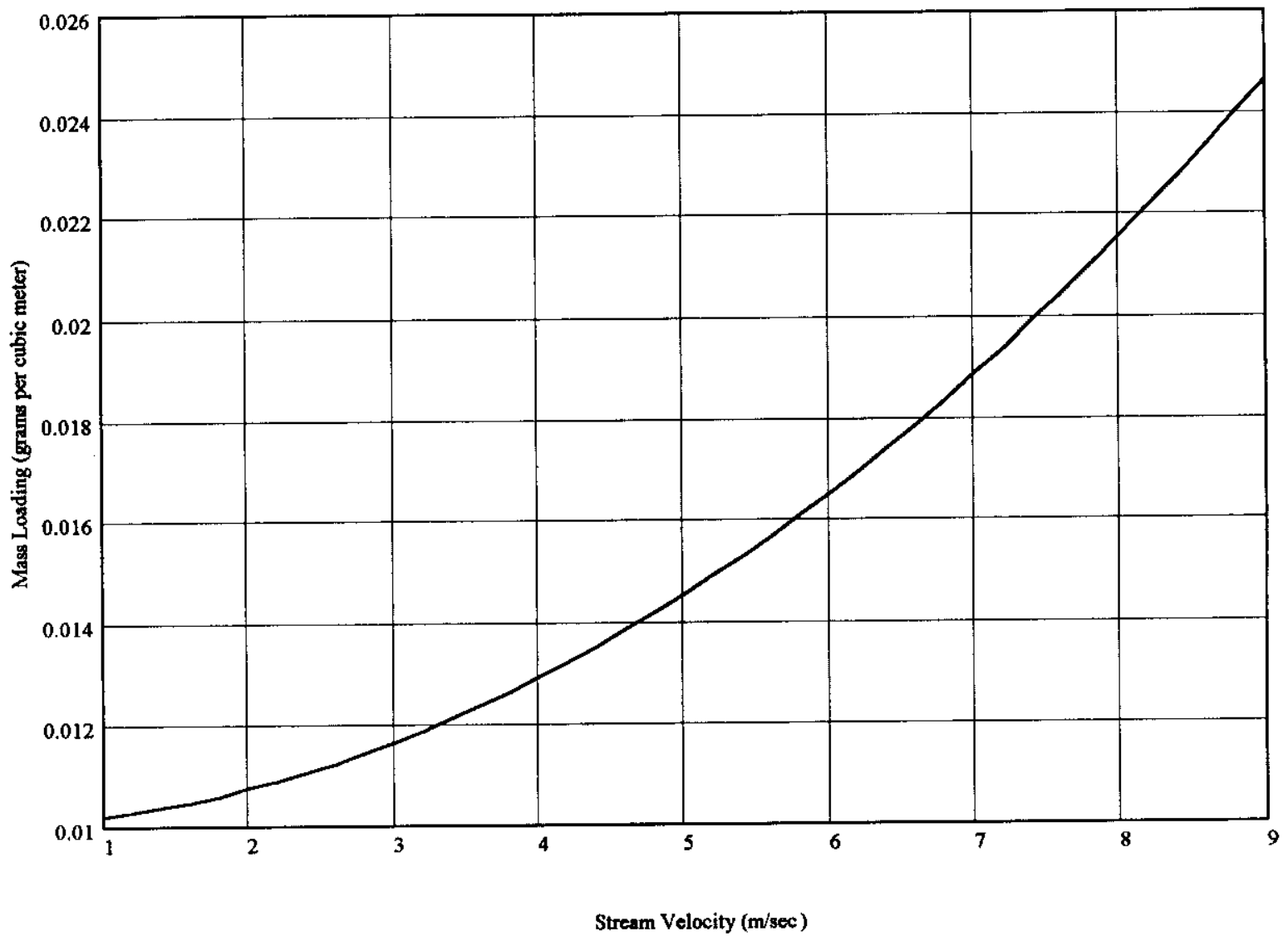


RPP-6023 REV 0

This page intentionally left blank. 


\subsection{AMMONIA SOURCE TERM}

This study determined the maximum levels of ammonia that could be expected in the vapor space of a DST receiving waste through a riser above the liquid surface. Henry's Law constants were used to predict the amount of ammonia that may be transported from one waste tank to a receiver DST and released to the DST vapor space. Henry's Law constants are calculated based on several empirical models for the solubility of gases in liquid salt mixtures. Appendix $\mathrm{E}$ provides the detail of Henry's Law constant for ammonia as discussed in RPP 4941.

An estimated ammonia source term is contained in Table 7-1 below, for the tanks with the worst ammonia source term. From the data in Table 7-1, it appears that no tank farm will require activated carbon filters for ammonia removal.

During the 241-SY-101 transfers, ammonia concentration limits of $3000 \mathrm{p} / \mathrm{m}$ vol contained in the SY farm HVAC notice of construction (NOC) were approached but never exceeded. Another ammonia emission limit (Comprehensive Environmental Response, Compensation, and Liability Act of $1980 \mathrm{CERCLA})$ is $45 \mathrm{~kg}(100 \mathrm{lb})$ of ammonia in a 24-hour period. Operations during the 241-SY-101 transfer were modified to comply with this limit.

The source term is for the receiver tank, not the source tank as was the case for VOCs, and assumes that the waste enters the receiver tank through a short drop leg. The source tank will have a lower concentration of ammonia during mixer pump operation based on release of retained gas. For the worst tank on Site, 241-SY-101, this amounts to about 20 percent of the source term. Should the receiver and source tanks be on the same HVAC header as is the case for 241-SY-101 to 241-SY-102 transfers, these ammonia concentrations will be additive. Ammonia concentration estimated from transferring $241-S Y-101$ (3000 p/m vol) with a short drop leg may be compared with the actual values recorded during the January 23,2000 , to January 31,2000 , transfer to $241-S Y-102(2,000 \mathrm{p} / \mathrm{m}$ vol $)$ with a subsurface drop leg. The $3000 \mathrm{p} / \mathrm{m}$ vol assumes a waste transfer rate of $530 \mathrm{~L} / \mathrm{min}(140 \mathrm{gal} / \mathrm{min})$. The actual transfer was $265 \mathrm{~L} / \mathrm{min}(70 \mathrm{gal} / \mathrm{min})$ waste diluted with $265 \mathrm{~L} / \mathrm{min}(70 \mathrm{gal} / \mathrm{min})$ water.

The values in Table 7-1 are from the Hedengren model (RPP-4941) which contains conservative assumptions on ammonia solubility. Laboratory tests have been performed to remove the some of the conservatism built into the model. Results are anticipated within the month. 


\section{RPP-6023 REV 0}

Table 7-1. Estimated Double-Shell Tank Stack Ammonia Concentrations.

\begin{tabular}{|c|c|}
\hline Source Tanl & 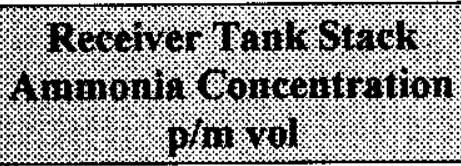 \\
\hline 241-SY-101 & 3000 \\
\hline 241-AN-103 & 1700 \\
\hline 241-AN-104 & 1000 \\
\hline 241-AW-104 & 70 \\
\hline 241-AN-102 & 225 \\
\hline 241-AN-107 & 60 \\
\hline 241-AY-101 & 50 \\
\hline 241-AY-102 & 25 \\
\hline
\end{tabular}

RPP-4941, 2000, Methodology for Predicting Flammable Gas Mixtures in Double-Contained Receiver Tanks, RPP-4941, Rev. 0, CH2M HILL Hanford Group, Inc., Richland, Washington.. 


\subsection{CONCLUSIONS AND RECOMMENDATIONS}

\subsection{CONCLUSIONS}

No extraordinary tank farm exhaust train cleanup appears to be needed for ammonia or for aerosols. However, the TAP concentration for SY and AN farms equal or exceed the SQER regulatory limits for 1,3-Butadiene and 1,4-Dioxan such that a high-efficiency gas adsorption (HEGA) unit should be installed as recommended by HNF-4245. Table 8-1 lists the constituents of concern for the various tank farms.

Table 8-1. Volatile Organic Compounds and Ammonia Emissions

\begin{tabular}{|c|c|c|c|c|c|c|}
\hline 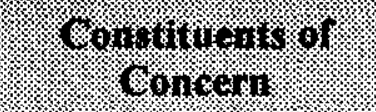 & 41411 & $\sqrt{6}$ & 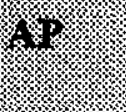 & $8 \times$ & 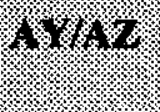 & 81 \\
\hline Total VOC (p/m vol) & $* *$ & 46 & $<46$ & 105 & 108 & 79 \\
\hline 1,3-Butadiene (lb/yr) & 0.5 & 21 & ND & ND & ND & 17 \\
\hline 1,4-Dioxan (lb/yr) & 10 & 12.4 & ND & 4.4 & ND & 10 \\
\hline Ammonia (lb/yr) & 17,500 & 3,900 & $<115$ & 161 & 115 & 6,900 \\
\hline
\end{tabular}

$\mathrm{ND}=$ not detected.

VOC $=$ volatile organic compounds

** Established by Notice of Construction, $241-\mathrm{C}-106$ NOC renegotiated to allow up to $450 \mathrm{p} / \mathrm{m}$ vol VOC.

This study was limited to Phase 1 and Phase 1 extended order tanks. In the future, the SY farm will receive waste from additional single-shell tank farms, some of which will have high concentrations of organics.

1. The estimated concentration of ammonia and specific volatile organic components (those present in sufficient quantities) that result during waste disturbance are contained in Sections 7.2 and 5.3 , respectively.

2. The nonradioactive chemical source terms for ammonia and those specific volatile organic components to be used in the design of treatment and monitoring equipment at the DST primary ventilation systems are contained in Sections 7.2 and 5.3, respectively.

3. The estimated quantitative volumes of aerosols that could be produced when using a drop leg below the surface of the waste verses vapor space discharge during transfer operations are contained in Section 6.4. 


\section{RPP-6023 REV 0}

\subsection{RECOMMENDATIONS}

The source term study should be extended to cover the tanks that must be retrieved, staged, and transferred to the Privatization Contractor. Data from 241-AZ-101 mixer pump operations should be incorporated as the data become available. The existing HEGA unit located on the AY/AZ tank farm HVAC should be studied to determine if the HEGA unit is capable of supporting the waste feed delivery. If cost effective, AN farm tanks should be sampled for retained gas because the emission rates are based on similar waste in 241-SY-101. New results may prove that HEGA filters are not required on AN farm. 


\subsection{REFERENCES}

Comprehensive Environmental Response, Compensation, and Liability Act of 1980

Hinds, W. C., 1982, Aerosol Technology/Properties, Behavior, and Measurement of Airborne Particles, John Wiley \& Sons, New York, New York.

HNF-3949, 1999, Tank Vapor Sampling and Data Analysis Package for Tank 241-C-106 Waste Retrieval Sluicing System Process Test, Sampled December 16, 1998, Rev. 0, Numatec Hanford Corporation, for Fluor Daniel Hanford, Inc., Richland, Washington.

HNF-4245, 1999, Alternatives Generation and Analysis for Double-Shell Tank Primary Ventilation Systems Emissions Control and Monitoring, Rev. 0, Numatec Hanford Corporation, Inc. for Lockheed Martin Hanford Corporation, Richland, Washington.

HNF-4261, 1999, Origins of Volatile Organic Compounds Emerging from Tank 241-C-106 During Sluicing, Rev. 1, Lockheed Martin Hanford Corporation, Richland, Washington.

HNF-4384, 1999, Decision Document for the DST Primary Ventilation Systems Emissions Control and Monitoring Decision, Numatec Hanford Corporation for Lockheed Martin Hanford Corporation, Richland, Washington.

HNF-4440, 1999, Tank Vapor Sampling and Data Analysis Package for Tank 241-C-106 Waste Retrieval Sluicing System Process Test Phase II, Sampled March 7, 1999, Rev. 0, Numatec Hanford Corporation, Richland, Washington.

HNF-4598, 1999, Tank Vapor Sampling and Analysis Data Package for Tank 241-C-106 Waste Retrieval Sluicing System Process Test Phase III, Sampled March 28, 1999, Rev. 0, Numatec Hanford Corporation, Richland, Washington.

HNF-SD-WM-DQO-021, 1999, Data Quality Objectives for Regulatory Requirements for Hazardous and Radioactive Air Emissions Sampling and Analysis, Rev. 1, Lockheed Martin Hanford Corporation, Richland, Washington.

HNF-SD-WM-SP-012, 1999, Tank Waste Remediation System Operation and Utilization Plan to Support Waste Feed Delivery, Rev. 1, Numatec Hanford Corporation, Lockheed Martin Hanford Corporation, and COGEMA Engineering Corporation for Fluor Daniel Hanford Inc. Richland, Washington.

Huckaby, J. L. 1986, Absorption of Sulfur Dioxide by Growing and Evaporating Water Droplets, Master's Thesis, University of Kentucky, Lexington, Kentucky.

Huckaby, J. L. and J. C. Evans, 1999, Letter Report to K. G. Carothers, Chemical Analysis of Air Samples Collected on November 18, 1998 during Sluicing Activities at Tank 241-C-106, Pacific Northwest National Laboratory, Richland, Washington.

Orr, J. C., Jr., 1966, Particulate Technology, The MacMillan Company, New York, New York. 
PNL-10185, 1995, Aerosol Characteristics in the Offgas from a Pilot Scale Sluicing Operation, Pacific Northwest Laboratory, Richland, Washington.

PNNL-11186, 1996, Comparison of Vapor Sampling System (VSS) and In Situ Vapor Sampling (ISVS) Methods on Tanks, C-107, BY-108, and S-102, Pacific Northwest National Laboratory, Richland, Washington.

PNNL-1 1450, 1997, Composition and Quantities of Retained Gas Measured in Hanford Waste Tanks 241-AW-101, $A-101, A N-105, A N-104$, and $A N-103$, Rev. 1, Pacific Northwest National Laboratory, Richland, Washington.

PNNL-12040, 1998, Regulatory Data Quality Objectives Supporting Tank Waste Remediation System Privatization Project, Rev. 0, Pacific Northwest National Laboratory, Richland, Washington.

PNNL-13000, 1999, Retain Gas Sampling for the Flammable Gas Program, Pacific Northwest National Laboratory, Richland, Washington.

RPP-4941, 2000, Methodology for Predicting Flammable Gas Mixtures in Double-Contained Receiver Tanks, Rev. 0, CH2M HULL Hanford Group, Inc., Richland, Washington.

WAC-173-401, 1999, "Operating Permit Regulation," Washington Administrative Code, as amended.

WAC-173-460, 1999, "Controls for New Sources of Toxic Pollutants," Washington Administrative Code, as amended.

WAC-173-460-150, 1999, "Class A Toxic Air Pollutants: Known, Probable And Potential Human Carcinogens And Acceptable Source Impact Levels," Washington Administrative Code, as amended.

WHC-SD-WM-ER-181, 1992, An Engineering Assessment of the Aerosol and Vapor Flammability in 241-C-103, Rev. 0, Westinghouse Hanford Company, Richland, Washington.

WHC-SD-WM-ER-514, 1995, Headspace Gas and Vapor Characterization Summary for the 43 Vapor Program Suspect Tanks, Rev. 1b, Westinghouse Hanford Company, Richland, Washington.

WHC-SD-WM-PE-045, 1992, Evaluation of August 1991 Tank 241-SY-101 Gas Release Event, Rev. 1, Westinghouse Hanford Company, Richland, Washington. 
RPP-6023 REV 0

APPENDIX A

CONCURRENT TANK OPERATIONS 
RPP-6023 REV 0

This page intentionally left blank. 


\section{APPENDIX A}

\section{CONCURRENT TANK OPERATIONS}

A significant assumption used in several studies and specifications is that only one tank in a farm is being retrieved from or transferred to at any one time. The purpose of this study was to verify this assumption. The transfer files from the Tank Waste Remediation System Operation and Utilization Plan to Support Waste Feed Delivery, HNF-SD-WM-SP-012 (Case 3S6D) were reviewed to determine if multiple tanks would be operated in a tank farm simultaneously. Case 3S6D was used for this study because it was expected to be representative of Hanford Tank Waste Operation Simulator models and should represent likely future cases.

Table 1 was extracted from the transfer tables and contains only the tank to tank transfers, while excluding salt well pumping. The transfer table includes only the duration of transfer pump operations. To account for the duration of mixer pump operation before tank transfer, an estimated duration for mixer pump operation was added to the transfer time in the transfer tables to arrive at a total mixer pump operating duration. Based on discussions with mixer pump design engineers, it was assumed that the mixer pumps must operate for two weeks to suspend $151,200 \mathrm{~L}(40,000 \mathrm{gal})$ of solids. Duration of mixer pump operation for smaller quantities of solids was calculated by prorating the two-week duration based on the ratio of solids.

Ignoring the times where only a one- or two-day overlap occurred, there were 14 occurrences of simultaneous tank transfers into and/or out of one tank farm during the next 20 years.

\section{Source Term Impacts}

The impact of concurrent tank operation on source term is minimal. According to Case 3S6D, two tanks in one farm were source tanks requiring simultaneous mixer pump operation on five occasions. This could affect the VOC emissions. On five different occasions, two tanks in one farm were receiver tanks that could affect ammonia emissions. However, since the worst-case tank for ammonia (241-SY-101) has been transferred to another SY tank without significant ammonia emission concerns, it is concluded that ammonia emission is not a major problem. The other four occasions of dual operation in a farm are when one tank is a source tank, and one tank is a receipt tank. Considering how infrequent the dual operations occurred during a 20 year period, it is a reasonable assumption that for the source term study, only one tank in a farm is being retrieved or transferred at a time. Sluicing of a single-shell tank does not contribute materially to emissions from DSTs. Based on experience from sluicing 241-C-106, most of the emissions occurred in the source tank and little in the receiver tank (241-AY-102). Salt well pumping does not materially add to the source term for the receiver tank and, if necessary, can be rescheduled to prevent concurrent operations.

\section{Electrical Study RPP-5228}

The impact of concurrent tank operations on electrical utilities is minimal. On five occasions, two tanks in one farm were source tanks requiring simultaneous mixer pump operation. Considering how infrequent the dual operations were over a 20 -year period, it is reasonable to assume that for the electrical study, only one tank in a farm is being retrieved or transferred at a time. Sluicing of single-shell tanks into AY tanks will not cause a problem as the electrical study included the simultaneous power needs of mixer pumps, transfer pumps and sluicing pumps. 
Water and Air Study RPP-5227

For the same reasons stated above, the impact of concurrent tank operations on the water and air study is minimal.

Table A-1. Tank Waste Remediation Services Operation and Utilization Plan Case 3S6D Transfer Tables. (6 sheets)

\begin{tabular}{|c|c|c|c|c|c|c|c|}
\hline 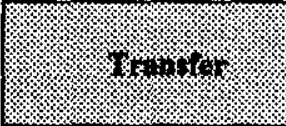 & 6.8 & 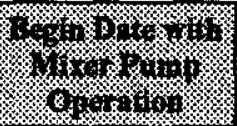 & 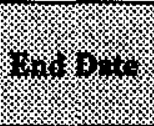 & $\frac{1}{4 y}$ & 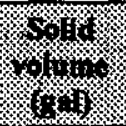 & 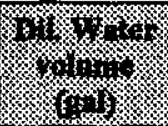 & 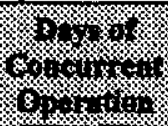 \\
\hline AP-107 to AW-102 & $1 / 1 / 99$ & $1 / 3 / 99$ & $1 / 3 / 99$ & 561000 & 0 & 0 & \\
\hline AW-106 to AW-102 & $1 / 9 / 99$ & $1 / 9 / 99$ & $1 / 13 / 99$ & 797900 & 0 & 0 & \\
\hline C-106 to AY-102 & $8 / 1 / 99$ & $8 / 1 / 99$ & $10 / 31 / 99$ & 57864 & 8136 & 0 & \\
\hline SY-102 to AP-107 & $8 / 26 / 99$ & $8 / 26 / 99$ & $8 / 27 / 99$ & 266000 & 10 & 0 & \\
\hline SY-102 to AP-107 & $8 / 30 / 99$ & $8 / 30 / 99$ & $8 / 31 / 99$ & 235000 & 9 & 0 & \\
\hline SY-101 to SY-102 & $11 / 15 / 99$ & $11 / 15 / 99$ & $11 / 15 / 99$ & 89995 & 5 & 0 & \\
\hline SY-102 to AP-104 & $11 / 22 / 99$ & $11 / 22 / 99$ & $11 / 23 / 99$ & 250000 & 10 & 0 & \\
\hline SY-102 to AP-107 & $11 / 24 / 99$ & $11 / 24 / 99$ & $11 / 25 / 99$ & 282900 & 11 & 0 & \\
\hline SY-101 to SY-102 & $12 / 1 / 99$ & $12 / 1 / 99$ & $12 / 1 / 99$ & 105000 & 6 & 0 & \\
\hline SY-102 to AP-104 & $12 / 10 / 99$ & $12 / 10 / 99$ & $12 / 11 / 99$ & 250000 & 10 & 0 & \\
\hline AP-107 to AW-102 & $12 / 29 / 99$ & $12 / 29 / 99$ & $12 / 30 / 99$ & 262600 & 0 & 0 & \\
\hline AW-106 to AW-102 & $1 / 4 / 00$ & $1 / 4 / 00$ & $1 / 8 / 00$ & 682000 & 0 & 0 & \\
\hline SY-101 to SY-102 & $1 / 5 / 00$ & $1 / 4 / 00$ & $1 / 5 / 00$ & 105000 & 6 & 0 & \\
\hline SY-102 to AP-104 & $1 / 14 / 00$ & $1 / 13 / 00$ & $1 / 15 / 00$ & 250000 & 10 & 0 & \\
\hline AP-107 to AW-102 & $2 / 5 / 00$ & $2 / 5 / 00$ & $2 / 6 / 00$ & 378500 & 0 & 0 & \\
\hline $\mathrm{AX}-101$ to $\mathrm{AN}-101$ & $8 / 10 / 00$ & $8 / 10 / 00$ & $12 / 5 / 00$ & 249200 & 0 & 149500 & \\
\hline AP-107 to AW-102 & $8 / 31 / 00$ & $8 / 31 / 00$ & $9 / 3 / 00$ & 609200 & 0 & 0 & \\
\hline SY-102 to AP-107 & $9 / 3 / 00$ & $9 / 3 / 00$ & $9 / 5 / 00$ & 517400 & 0 & 0 & \\
\hline AN-101 to AN-106 & $12 / 5 / 00$ & $12 / 5 / 00$ & $12 / 11 / 00$ & 1105000 & 0 & 0 & \\
\hline$A X-101$ to $A N-101$ & $12 / 11 / 00$ & $12 / 11 / 00$ & $5 / 25 / 02$ & 194800 & 0 & 116900 & \\
\hline$A-101$ to $A N-101$ & $12 / 11 / 00$ & $12 / 11 / 00$ & $10 / 6 / 02$ & 200500 & 0 & 120300 & \\
\hline SY-102 to AP-107 & $12 / 13 / 00$ & $12 / 13 / 00$ & $12 / 15 / 00$ & 520300 & 0 & 0 & \\
\hline AP-107 to AW-102 & $1 / 1 / 01$ & $1 / 1 / 01$ & $1 / 3 / 01$ & 451300 & 0 & 0 & \\
\hline AW-106 to AP-106 & $4 / 24 / 01$ & $4 / 24 / 01$ & $4 / 29 / 01$ & 887400 & 0 & 0 & \\
\hline AW-104 to AW-102 & $6 / 1 / 01$ & $6 / 1 / 01$ & $6 / 2 / 01$ & 319200 & 0 & 0 & \\
\hline SY-102 to AP-107 & $7 / 6 / 01$ & $7 / 6 / 01$ & $7 / 6 / 01$ & 152900 & 0 & 0 & \\
\hline AW-106 to AW-102 & $12 / 24 / 01$ & $12 / 24 / 01$ & $12 / 27 / 01$ & 681900 & 0 & 0 & \\
\hline AW-104 to AW-102 & $12 / 27 / 01$ & $12 / 27 / 01$ & $12 / 29 / 01$ & 378600 & 0 & 0 & \\
\hline AP-107 to AW-102 & $1 / 4 / 02$ & $1 / 4 / 02$ & $1 / 9 / 02$ & 1061000 & 0 & 0 & \\
\hline SY-102 to AP-107 & $1 / 9 / 02$ & $1 / 9 / 02$ & $1 / 10 / 02$ & 378900 & 0 & 0 & \\
\hline AW-104 to AW-102 & $1 / 10 / 02$ & $1 / 10 / 02$ & $1 / 11 / 02$ & 162700 & 0 & 0 & 1 \\
\hline AW-106 to AP-106 & $1 / 10 / 02$ & $1 / 10 / 02$ & $1 / 11 / 02$ & 161600 & 0 & 0 & \\
\hline AW-106 to AW-104 & $1 / 12 / 02$ & $1 / 12 / 02$ & $1 / 17 / 02$ & 885500 & 0 & 0 & \\
\hline SY-102 to AP-107 & $3 / 12 / 02$ & $3 / 12 / 02$ & $3 / 13 / 02$ & 445000 & 0 & 0 & \\
\hline
\end{tabular}


Table A-1. Tank Waste Remediation Services Operation and Utilization Plan Case 3S6D Transfer Tables. (6 sheets)

\begin{tabular}{|c|c|c|c|c|c|c|c|}
\hline $6 \%$ & 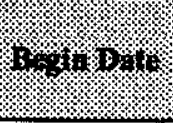 & 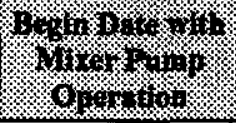 & W.o. & 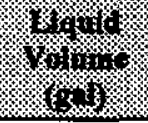 & 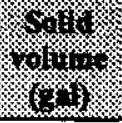 & 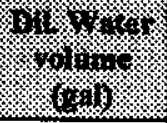 & 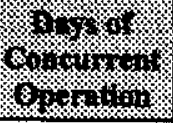 \\
\hline AP-107 to AW-102 & $3 / 13 / 02$ & $3 / 13 / 02$ & $3 / 15 / 02$ & 341300 & 0 & 0 & \\
\hline SY-102 to AP-107 & $3 / 15 / 02$ & $3 / 15 / 02$ & $3 / 15 / 02$ & 76507 & 0 & 0 & \\
\hline SY-102 to AP-107 & $6 / 16 / 02$ & $6 / 16 / 02$ & $6 / 16 / 02$ & 190100 & 0 & 0 & \\
\hline AP-107 to AW-102 & $8 / 21 / 02$ & $8 / 21 / 02$ & $8 / 26 / 02$ & 1061000 & 0 & 0 & \\
\hline SY-102 to AP-107 & $8 / 26 / 02$ & $8 / 26 / 02$ & $8 / 28 / 02$ & 327500 & 0 & 0 & \\
\hline AN-101 to AP-103 & $7 / 1 / 03$ & $7 / 1 / 03$ & $7 / 4 / 03$ & 644100 & 0 & 0 & \\
\hline $\mathrm{AP}-107$ to $\mathrm{AW}-102$ & $10 / 1 / 03$ & $10 / 1 / 03$ & $10 / 3 / 03$ & 319200 & 0 & 0 & \\
\hline S-103 to SY-102 & $1 / 1 / 04$ & $12 / 31 / 03$ & $1 / 28 / 04$ & 99471 & 529 & 0 & \\
\hline $\mathrm{AP}-107$ to $\mathrm{AW}-102$ & $10 / 1 / 04$ & $10 / 1 / 04$ & $10 / 1 / 04$ & 1299 & 0 & 0 & 1 \\
\hline$A W-106$ to $A W-103$ & $10 / 1 / 04$ & $10 / 1 / 04$ & $10 / 4 / 04$ & 634000 & 0 & 0 & \\
\hline AW-106 to AP-105 & $10 / 4 / 04$ & $10 / 4 / 04$ & $10 / 5 / 04$ & 265800 & 0 & 0 & \\
\hline $\mathrm{AN}-106$ to $\mathrm{AW}-102$ & $11 / 1 / 04$ & $11 / 1 / 04$ & $11 / 1 / 04$ & 16800 & 0 & 0 & \\
\hline AW-106 to AW-102 & $6 / 3 / 05$ & $6 / 3 / 05$ & $6 / 6 / 05$ & 682000 & 0 & 0 & \\
\hline AN-106 to AW-102 & $6 / 6 / 05$ & $6 / 6 / 05$ & $6 / 8 / 05$ & 378500 & 0 & 0 & \\
\hline AP-107 to AW-102 & $6 / 14 / 05$ & $6 / 14 / 05$ & $6 / 19 / 05$ & 1061000 & 0 & 0 & \\
\hline AN-101 to AP-107 & $6 / 19 / 05$ & $6 / 19 / 05$ & $6 / 19 / 05$ & 180500 & 0 & 0 & \\
\hline AN-104 to $\mathrm{AN}-101$ & $6 / 19 / 05$ & $6 / 18 / 05$ & $6 / 24 / 05$ & 676000 & 1665 & 364000 & 1 \\
\hline AN-106 to AW-102 & $6 / 20 / 05$ & $6 / 20 / 05$ & $6 / 20 / 05$ & 100800 & 0 & 0 & \\
\hline AW- 106 to AP- 105 & $6 / 20 / 05$ & $6 / 20 / 05$ & $6 / 20 / 05$ & 112200 & 0 & 0 & \\
\hline AN-106 to AW-102 & $6 / 21 / 05$ & $6 / 21 / 05$ & $6 / 22 / 05$ & 184800 & 0 & 0 & \\
\hline AW-106 to AW-105 & $6 / 21 / 05$ & $6 / 21 / 05$ & $6 / 25 / 05$ & 714000 & 0 & 0 & \\
\hline AW-106 to AW-102 & $6 / 28 / 05$ & $6 / 28 / 05$ & $7 / 2 / 05$ & 852500 & 0 & 0 & \\
\hline AN-106 to AW-102 & $7 / 2 / 05$ & $7 / 2 / 05$ & $7 / 3 / 05$ & 208000 & 0 & 0 & \\
\hline AN-101 to AN-104 & $1 / 24 / 06$ & $1 / 24 / 06$ & $1 / 26 / 06$ & 587500 & 0 & 0 & \\
\hline AN-106 to AW-102 & $1 / 29 / 06$ & $1 / 29 / 06$ & $1 / 30 / 06$ & 210600 & 0 & 0 & \\
\hline AN-104 to AN-101 & $2 / 24 / 06$ & $2 / 24 / 06$ & $2 / 25 / 06$ & 300000 & 0 & 0 & \\
\hline AN-101 to AN-104 & $3 / 28 / 06$ & $3 / 28 / 06$ & $3 / 29 / 06$ & 300000 & 0 & 0 & \\
\hline AN-104 to AN-101 & $4 / 28 / 06$ & 4/28/06 & $4 / 29 / 06$ & 300000 & 0 & 0 & \\
\hline AN-101 to AN-104 & $5 / 30 / 06$ & $5 / 30 / 06$ & $5 / 31 / 06$ & 298100 & 0 & 0 & \\
\hline AN-104 to AN-101 & $6 / 30 / 06$ & $6 / 30 / 06$ & $7 / 1 / 06$ & 300000 & 0 & 0 & \\
\hline AP-107 to AW-102 & $1 / 1 / 08$ & $1 / 1 / 08$ & $1 / 5 / 08$ & 849900 & 0 & 0 & \\
\hline C-104 to AY-101 & $1 / 1 / 08$ & $12 / 15 / 07$ & $6 / 6 / 08$ & 718800 & 48093 & 0 & \\
\hline SY-102 to AP-107 & $1 / 5 / 08$ & $1 / 5 / 08$ & $1 / 7 / 08$ & 679200 & 0 & 0 & \\
\hline$A W-106$ to $A W-102$ & $1 / 6 / 08$ & $1 / 6 / 08$ & $1 / 8 / 08$ & 319200 & 0 & 0 & \\
\hline AW-106 to AW-102 & $1 / 10 / 08$ & $1 / 10 / 08$ & $1 / 13 / 08$ & 487200 & 0 & 0 & \\
\hline AW-106 to AW-102 & $1 / 17 / 08$ & $1 / 17 / 08$ & $1 / 20 / 08$ & 756000 & 0 & 0 & \\
\hline AP-107 to AW-102 & $3 / 1 / 09$ & $3 / 1 / 09$ & $3 / 6 / 09$ & 1061000 & 0 & 0 & \\
\hline AW-106 to AP-108 & $3 / 6 / 09$ & $3 / 6 / 09$ & $3 / 11 / 09$ & 882800 & 0 & 0 & \\
\hline $\mathrm{AN}-102$ to $\mathrm{AP}-107$ & $3 / 28 / 10$ & $3 / 27 / 10$ & $3 / 28 / 10$ & 140400 & 54 & 0 & 1 \\
\hline
\end{tabular}


Table A-1. Tank Waste Remediation Services Operation and Utilization Plan Case 3S6D Transfer Tables. (6 sheets)

\begin{tabular}{|c|c|c|c|c|c|c|c|}
\hline \% & $x^{2} x_{1}+y_{1}$ & 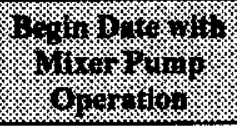 & $x_{1} x_{0}+4$ & 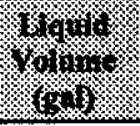 & $\frac{x_{1}}{4+1}$ & $\frac{1}{310}$ & 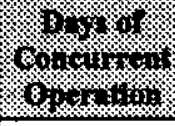 \\
\hline AN-105 to AN-102 & $3 / 28 / 10$ & $3 / 27 / 10$ & $3 / 31 / 10$ & 453600 & 1082 & 225200 & \\
\hline SY-102 to AN-104 & $9 / 29 / 10$ & $9 / 27 / 10$ & $10 / 1 / 10$ & 432900 & 5320 & 0 & 6 \\
\hline AN-104 to AZ-101 & $10 / 1 / 10$ & $9 / 25 / 10$ & $10 / 3 / 10$ & 525900 & 15280 & 0 & \\
\hline SY-102 to AN-104 & $10 / 3 / 10$ & $10 / 3 / 10$ & $10 / 3 / 10$ & 3861 & 0 & 0 & \\
\hline SY-102 to AP-107 & $7 / 1 / 11$ & $7 / 1 / 11$ & $7 / 1 / 11$ & 15372 & 0 & 0 & \\
\hline SY-101 to SY-102 & $7 / 5 / 11$ & $7 / 4 / 11$ & $7 / 9 / 11$ & 602500 & 1533 & 295900 & \\
\hline SY-102 to AN-101 & $7 / 9 / 11$ & $7 / 9 / 11$ & $7 / 12 / 11$ & 889300 & 0 & 0 & \\
\hline SY-101 to AN-104 & $1 / 1 / 12$ & $12 / 31 / 11$ & $1 / 2 / 12$ & 272100 & 692 & 0 & \\
\hline AN-103 to AN-102 & $4 / 1 / 12$ & $3 / 31 / 12$ & $4 / 6 / 12$ & 469800 & 1382 & 420200 & \\
\hline C-107 to AY-102 & $5 / 1 / 12$ & $4 / 21 / 12$ & $9 / 12 / 12$ & 467100 & 27406 & 0 & \\
\hline $\mathrm{AW}-101$ to $\mathrm{AN}-105$ & $8 / 21 / 12$ & $8 / 20 / 12$ & $8 / 24 / 12$ & 451300 & 872 & 247800 & \\
\hline AP-107 to AW-102 & $10 / 1 / 12$ & $10 / 1 / 12$ & $10 / 1 / 12$ & 16800 & 0 & 0 & \\
\hline AW-106 to AW-102 & $10 / 6 / 12$ & $10 / 6 / 12$ & $10 / 10 / 12$ & 681600 & 0 & 0 & \\
\hline AP-107 to AW-102 & $10 / 10 / 12$ & $10 / 10 / 12$ & $10 / 12 / 12$ & 378900 & 0 & 0 & \\
\hline AW-106 to AW-102 & $10 / 17 / 12$ & $10 / 17 / 12$ & $10 / 20 / 12$ & 681800 & 0 & 0 & \\
\hline AP-104 to AP-107 & $1 / 6 / 13$ & $1 / 5 / 13$ & $1 / 6 / 13$ & 140500 & 1 & 0 & \\
\hline AW-104 to AP-104 & $1 / 6 / 13$ & $1 / 5 / 13$ & $1 / 9 / 13$ & 558000 & 1293 & 105100 & \\
\hline SY-103 to AN-101 & $5 / 1 / 13$ & $4 / 30 / 13$ & $5 / 3 / 13$ & 312100 & 783 & 112100 & \\
\hline S-102 to SY-103 & $5 / 3 / 13$ & $5 / 1 / 13$ & $8 / 15 / 13$ & 321800 & 3597 & 0 & \\
\hline $\mathrm{S}-103$ to SY-103 & $5 / 3 / 13$ & $5 / 2 / 13$ & $8 / 15 / 13$ & 388100 & 1472 & 0 & \\
\hline SY-103 to AN-104 & $8 / 16 / 13$ & $8 / 3 / 13$ & $8 / 19 / 13$ & 802800 & 37057 & 0 & 1 \\
\hline AN-104 to AP-102 & $8 / 19 / 13$ & $8 / 18 / 13$ & $8 / 20 / 13$ & 49283 & 1717 & 0 & \\
\hline S-102 to SY-103 & $8 / 19 / 13$ & $8 / 18 / 13$ & $10 / 28 / 13$. & 217500 & 2431 & 0 & \\
\hline S-103 to SY-103 & $8 / 19 / 13$ & $8 / 18 / 13$ & $10 / 28 / 13$ & 261700 & 992 & 0 & \\
\hline AN-104 to AN-106 & $8 / 20 / 13$ & $8 / 7 / 13$ & $8 / 25 / 13$ & 1030000 & 35882 & 0 & \\
\hline AP-107 to AW-102 & $10 / 1 / 13$ & $10 / 1 / 13$ & $10 / 3 / 13$ & 378700 & 0 & 0 & \\
\hline AP-106 to AN-102 & $10 / 8 / 13$ & $10 / 8 / 13$ & $10 / 11 / 13$ & 558500 & 0 & 10430 & \\
\hline AW-106 to AW-102 & $10 / 8 / 13$ & $10 / 8 / 13$ & $10 / 12 / 13$ & 681900 & 0 & 0 & \\
\hline AN-104 to AN-106 & $10 / 31 / 13$ & $10 / 30 / 13$ & $10 / 31 / 13$ & 32770 & 731 & 0 & 6 \\
\hline AN-104 to AP-101 & $10 / 31 / 13$ & $10 / 25 / 13$ & $11 / 4 / 13$ & 711000 & 15851 & 0 & \\
\hline S-102 to SY-103 & $10 / 31 / 13$ & $10 / 29 / 13$ & $3 / 16 / 14$ & 421400 & 4710 & 0 & \\
\hline S-105 to SY-103 & $10 / 31 / 13$ & $10 / 30 / 13$ & $3 / 16 / 14$ & 688700 & 1718 & 0 & \\
\hline AW-103 to AY-102 & $12 / 12 / 13$ & $12 / 7 / 13$ & $12 / 13 / 13$ & 337700 & 14041 & 0 & \\
\hline SY-103 to AN-104 & $3 / 17 / 14$ & $3 / 14 / 14$ & $3 / 21 / 14$ & 1110000 & 6848 & 0 & 1 \\
\hline AN-104 to AP-101 & $3 / 21 / 14$ & $3 / 20 / 14$ & $3 / 23 / 14$ & 387100 & 2537 & 0 & \\
\hline S-102 to SY-103 & $3 / 21 / 14$ & $3 / 20 / 14$ & $4 / 4 / 14$ & 41943 & 469 & 0 & \\
\hline S-105 to SY-103 & $3 / 21 / 14$ & $3 / 20 / 14$ & $4 / 4 / 14$ & 68929 & 172 & 0 & \\
\hline AN-104 to AN-103 & $4 / 6 / 14$ & $4 / 4 / 14$ & $4 / 10 / 14$ & 722600 & 4732 & 0 & 1 \\
\hline SY-103 to AN-104 & $4 / 10 / 14$ & $4 / 9 / 14$ & $4 / 11 / 14$ & 110900 & 649 & 0 & \\
\hline
\end{tabular}


Table A-1. Tank Waste Remediation Services Operation and Utilization Plan Case 3S6D Transfer Tables. (6 sheets)

\begin{tabular}{|c|c|c|c|c|c|c|c|}
\hline 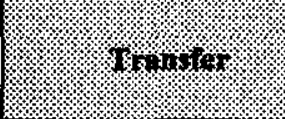 & 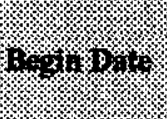 & 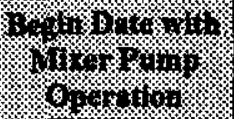 & 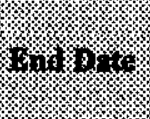 & 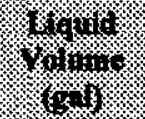 & ong & \%xin & אx. \\
\hline S-105 to SY-103 & $4 / 11 / 14$ & $4 / 10 / 14$ & $8 / 6 / 14$ & 593900 & 1481 & 0 & \\
\hline S-106 to SY-103 & $4 / 11 / 14$ & $4 / 10 / 14$ & $8 / 6 / 14$ & 518700 & 2396 & 0 & \\
\hline SY-103 to AN-104 & $8 / 7 / 14$ & $8 / 5 / 14$ & $8 / 10 / 14$ & 1001000 & 3547 & 0 & \\
\hline S-105 to SY-103 & $8 / 10 / 14$ & $8 / 9 / 14$ & $8 / 24 / 14$ & 65660 & 164 & 0 & \\
\hline S-106 to SY-103 & $8 / 10 / 14$ & $8 / 9 / 14$ & $8 / 24 / 14$ & 57235 & 264 & 0 & \\
\hline AN-104 to AN-103 & $8 / 11 / 14$ & $8 / 10 / 14$ & $8 / 13 / 14$ & 387700 & 1488 & 0 & \\
\hline AN-104 to AN-105 & $10 / 4 / 14$ & $10 / 3 / 14$ & $10 / 8 / 14$ & 725000 & 2781 & 0 & 1 \\
\hline SY-103 to AN-104 & $10 / 8 / 14$ & $10 / 7 / 14$ & $10 / 9 / 14$ & 234000 & 822 & 0 & \\
\hline S-106 to SY-103 & $10 / 9 / 14$ & $10 / 8 / 14$ & $2 / 16 / 15$ & 572000 & 2642 & 0 & \\
\hline S-108 to SY-103 & $10 / 9 / 14$ & $10 / 8 / 14$ & $2 / 16 / 15$ & 539800 & 2058 & 0 & \\
\hline AP-107 to AW-102 & $12 / 1 / 14$ & $12 / 1 / 14$ & $12 / 3 / 14$ & 378600 & 0 & 0 & \\
\hline AW-106 to AW-102 & $12 / 8 / 14$ & $12 / 8 / 14$ & $12 / 11 / 14$ & 682000 & 0 & 0 & \\
\hline SY-103 to AN-104 & $2 / 16 / 15$ & $2 / 14 / 15$ & $2 / 19 / 15$ & 878000 & 3696 & 0 & \\
\hline S-106 to SY-103 & $2 / 19 / 15$ & $2 / 18 / 15$ & $3 / 20 / 15$ & 128700 & 594 & 0 & \\
\hline S-108 to SY-103 & $2 / 19 / 15$ & $2 / 18 / 15$ & $3 / 20 / 15$ & 121200 & 462 & 0 & \\
\hline AN-104 to $\mathrm{AN}-105$ & $2 / 20 / 15$ & $2 / 19 / 15$ & $2 / 21 / 15$ & 205000 & 832 & 0 & \\
\hline AN-104 to AW-101 & $3 / 4 / 15$ & $3 / 2 / 15$ & $3 / 8 / 15$ & 907500 & 3681 & 0 & \\
\hline SY-103 to AN-104 & $3 / 20 / 15$ & $3 / 19 / 15$ & $3 / 22 / 15$ & 483700 & 2041 & 0 & 1 \\
\hline $\mathrm{AN}-104$ to $\mathrm{AW}-101$ & $3 / 22 / 15$ & $3 / 21 / 15$ & $3 / 23 / 15$ & 204500 & 860 & 0 & \\
\hline S-108 to SY-103 & $3 / 22 / 15$ & $3 / 21 / 15$ & $7 / 25 / 15$ & 516200 & 1968 & 0 & \\
\hline S-109 to SY-103 & $3 / 22 / 15$ & $3 / 21 / 15$ & $7 / 25 / 15$ & 596500 & 1784 & 0 & \\
\hline AP-105 to AP-104 & $9 / 25 / 15$ & $9 / 24 / 15$ & $9 / 29 / 15$ & 560200 & 571 & 125900 & \\
\hline AW-103 to AW-104 & $10 / 31 / 15$ & $10 / 27 / 15$ & $11 / 1 / 15$ & 241200 & 10030 & 0 & 1 \\
\hline AN-104 to AW-103 & $11 / 1 / 15$ & $10 / 31 / 15$ & $11 / 3 / 15$ & 280200 & 1177 & 0 & 2 \\
\hline SY-103 to AN-104 & $11 / 3 / 15$ & $11 / 1 / 15$ & $11 / 7 / 15$ & 1113000 & 3774 & 0 & 1 \\
\hline AN-104 to AW-103 & $11 / 7 / 15$ & $11 / 6 / 15$ & $11 / 9 / 15$ & 320400 & 1093 & 0 & \\
\hline S-108 to SY-103 & $11 / 7 / 15$ & $11 / 6 / 15$ & $1 / 13 / 16$ & 281000 & 1071 & 0 & \\
\hline S-109 to SY-103 & $11 / 7 / 15$ & $11 / 6 / 15$ & $1 / 13 / 16$ & 324700 & 971 & 0 & \\
\hline $\mathrm{AN}-104$ to $\mathrm{AN}-101$ & $2 / 2 / 16$ & $2 / 1 / 16$ & $2 / 6 / 16$ & 792800 & 2703 & 0 & 1 \\
\hline SY-103 to AN-104 & $2 / 6 / 16$ & $2 / 5 / 16$ & $2 / 8 / 16$ & 605700 & 2043 & 0 & 1 \\
\hline AN-104 to AN-101 & $2 / 8 / 16$ & $2 / 7 / 16$ & $2 / 10 / 16$ & 319900 & 1079 & 0 & \\
\hline S-109 to SY-103 & $2 / 8 / 16$ & $2 / 7 / 16$ & $5 / 30 / 16$ & 535800 & 1602 & 0 & \\
\hline S-112 to SY-103 & $2 / 8 / 16$ & $2 / 7 / 16$ & $5 / 30 / 16$ & 576300 & 2823 & 0 & \\
\hline $\mathrm{AN}-104$ to $\mathrm{AN}-102$ & $4 / 28 / 16$ & $4 / 27 / 16$ & $4 / 30 / 16$ & 286800 & 965 & 0 & \\
\hline SY-103 to AN-104 & $5 / 31 / 16$ & $5 / 29 / 16$ & $6 / 4 / 16$ & 1112000 & 4410 & 0 & 2 \\
\hline AN-104 to AN-102 & $6 / 4 / 16$ & $6 / 2 / 16$ & $6 / 8 / 16$ & 825500 & 3261 & 0 & \\
\hline S-109 to SY-103 & $6 / 4 / 16$ & $6 / 3 / 16$ & $7 / 4 / 16$ & 145500 & 435 & 0 & \\
\hline S-112 to SY-103 & $6 / 4 / 16$ & $6 / 3 / 16$ & $7 / 4 / 16$ & 156700 & 768 & 0 & \\
\hline AN-104 to AP-106 & $8 / 22 / 16$ & $8 / 21 / 16$ & $8 / 23 / 16$ & 287100 & 1133 & 0 & 1 \\
\hline
\end{tabular}


Table A-1. Tank Waste Remediation Services Operation and Utilization Plan Case 3S6D Transfer Tables. (6 sheets)

\begin{tabular}{|c|c|c|c|c|c|c|c|}
\hline Why & (x) & 8. & 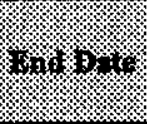 & 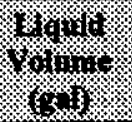 & 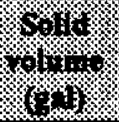 & 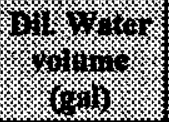 & ms \\
\hline SY-103 to AN-104 & $8 / 23 / 16$ & $8 / 22 / 16$ & $8 / 24 / 16$ & 302200 & 1202 & 0 & \\
\hline S-107 to SY-103 & $8 / 24 / 16$ & $8 / 18 / 16$ & $12 / 19 / 16$ & 492100 & 16734 & 0 & \\
\hline S-112 to SY-103 & $8 / 24 / 16$ & $8 / 22 / 16$ & $12 / 19 / 16$ & 604700 & 2962 & 0 & \\
\hline $\mathrm{AP}-107$ to $\mathrm{AW}-102$ & $9 / 1 / 16$ & $9 / 1 / 16$ & $9 / 3 / 16$ & 378500 & 0 & 0 & \\
\hline SY-103 to AN-104 & $12 / 20 / 16$ & $12 / 15 / 16$ & $12 / 23 / 16$ & 799000 & 14077 & 0 & 4 \\
\hline AN-104 to AP-106 & $12 / 23 / 16$ & $12 / 19 / 16$ & $12 / 28 / 16$ & 817100 & 11141 & 0 & \\
\hline S-107 to SY-103 & $12 / 23 / 16$ & $12 / 20 / 16$ & $2 / 15 / 17$ & 226800 & 7713 & 0 & \\
\hline S-112 to SY-103 & $12 / 23 / 16$ & $12 / 22 / 16$ & $2 / 15 / 17$ & 278800 & 1366 & 0 & \\
\hline AN-104 to AP-101 & $12 / 28 / 16$ & $12 / 26 / 16$ & $12 / 29 / 16$ & 284900 & 3878 & 0 & \\
\hline SY-103 to AN-104 & $2 / 15 / 17$ & $2 / 9 / 17$ & $2 / 18 / 17$ & 803800 & 14326 & 0 & 5 \\
\hline AN-104 to AP-101 & $2 / 18 / 17$ & $2 / 13 / 17$ & $2 / 21 / 17$ & 700100 & 12374 & 0 & \\
\hline S-107 to SY-103 & $2 / 18 / 17$ & $2 / 14 / 17$ & $4 / 25 / 17$ & 276500 & 9401 & 0 & \\
\hline S-110 to SY-103 & $2 / 18 / 17$ & $2 / 14 / 17$ & $4 / 25 / 17$ & 329500 & 10808 & 0 & \\
\hline AN-104 to AN-105 & $5 / 16 / 17$ & $5 / 15 / 17$ & $5 / 16 / 17$ & 104800 & 1845 & 0 & 7 \\
\hline SY-103 to AN-104 & $5 / 16 / 17$ & $5 / 9 / 17$ & $5 / 18 / 17$ & 606400 & 19820 & 0 & 7 \\
\hline AN-104 to AN-105 & $5 / 18 / 17$ & $5 / 11 / 17$ & $5 / 22 / 17$ & 607300 & 19443 & 0 & \\
\hline S-110 to SY-103 & $5 / 18 / 17$ & $5 / 7 / 17$ & $11 / 19 / 17$ & 921800 & 30232 & 0 & \\
\hline SY-103 to AN-104 & $11 / 19 / 17$ & $11 / 8 / 17$ & $11 / 22 / 17$ & 921800 & 30229 & 0 & 3 \\
\hline AN-104 to AN-105 & $11 / 22 / 17$ & $11 / 19 / 17$ & $11 / 23 / 17$ & 218800 & 7167 & 0 & 9 \\
\hline AN-104 to AP-104 & $11 / 23 / 17$ & $11 / 14 / 17$ & $11 / 27 / 17$ & 704000 & 23044 & 0 & \\
\hline A-101 to AY-102 & $4 / 6 / 18$ & $4 / 4 / 18$ & $8 / 23 / 18$ & 400100 & 5563 & 0 & \\
\hline$A X-103$ to $A Y-102$ & $4 / 6 / 18$ & $4 / 4 / 18$ & $8 / 23 / 18$ & 331100 & 3088 & 0 & \\
\hline SY-102 to AN-104 & $6 / 25 / 18$ & $6 / 20 / 18$ & $6 / 28 / 18$ & 989400 & 11913 & 0 & \\
\hline AP-107 to AW-102 & $7 / 1 / 18$ & $7 / 1 / 18$ & $7 / 6 / 18$ & 1061000 & 0 & 0 & \\
\hline $\mathrm{AW}-106$ to $\mathrm{AW}-102$ & $7 / 8 / 18$ & $7 / 8 / 18$ & $7 / 9 / 18$ & 319200 & 0 & 0 & 2 \\
\hline AN-104 to AW-105 & $7 / 9 / 18$ & $7 / 7 / 18$ & $7 / 10 / 18$ & 354500 & 4458 & 0 & \\
\hline AW-106 to AW-102 & $7 / 12 / 18$ & $7 / 12 / 18$ & $7 / 14 / 18$ & 487200 & 0 & 0 & \\
\hline AN-104 to AP-108 & $7 / 15 / 18$ & $7 / 12 / 18$ & $7 / 18 / 18$ & 635400 & 7985 & 0 & \\
\hline AW-106 to AW-102 & $7 / 18 / 18$ & $7 / 18 / 18$ & $7 / 22 / 18$ & 756000 & 0 & 0 & \\
\hline SY-102 to AN-104 & $11 / 21 / 18$ & $11 / 17 / 18$ & $11 / 25 / 18$ & 990300 & 11002 & 0 & \\
\hline $\mathrm{AY}-102$ to $\mathrm{AP}-102$ & $12 / 4 / 18$ & $11 / 30 / 18$ & $12 / 8 / 18$ & 730700 & 9650 & 0 & \\
\hline A-101 to AY-102 & $12 / 8 / 18$ & $12 / 5 / 18$ & $5 / 24 / 19$ & 478400 & 6653 & 0 & \\
\hline AX-101 to AY-102 & $12 / 8 / 18$ & $12 / 7 / 18$ & $5 / 24 / 19$ & 438000 & 1422 & 0 & \\
\hline AN-104 to AW-104 & $1 / 20 / 19$ & $1 / 17 / 19$ & $1 / 24 / 19$ & 698700 & 7785 & 0 & \\
\hline AN-104 to AN-107 & $3 / 26 / 19$ & $3 / 24 / 19$ & $3 / 28 / 19$ & 292600 & 3256 & 0 & \\
\hline AY-102 to AN-106 & $5 / 24 / 19$ & $5 / 21 / 19$ & $5 / 29 / 19$ & 916300 & 8190 & 0 & \\
\hline A-101 to AY-102 & $5 / 29 / 19$ & $5 / 26 / 19$ & $11 / 11 / 19$ & 478400 & 6653 & 0 & \\
\hline AX-101 to AY-102 & $5 / 29 / 19$ & $5 / 28 / 19$ & $11 / 11 / 19$ & 438000 & 1422 & 0 & \\
\hline AY-102 to AN-106 & $11 / 12 / 19$ & $11 / 11 / 19$ & $11 / 13 / 19$ & 190300 & 1678 & 0 & 3 \\
\hline
\end{tabular}


Table A-1. Tank Waste Remediation Services Operation and Utilization Plan Case 3S6D Transfer Tables. (6 sheets)

\begin{tabular}{|c|c|c|c|c|c|c|c|}
\hline 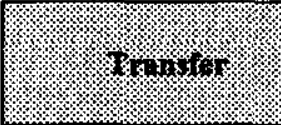 & 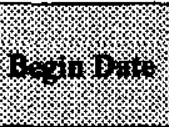 & 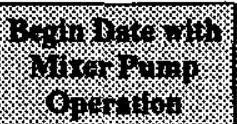 & \%ons & 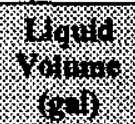 & 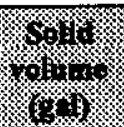 & 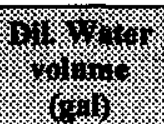 & 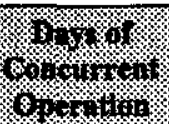 \\
\hline $\mathrm{AY}-102$ to $\mathrm{AN}-103$ & $11 / 13 / 19$ & $11 / 10 / 19$ & $11 / 17 / 19$ & 726600 & 6401 & 0 & \\
\hline A-101 to AY-102 & $11 / 17 / 19$ & $11 / 16 / 19$ & $1 / 21 / 20$ & 186700 & 2596 & 0 & \\
\hline$A X-101$ to $A Y-102$ & $11 / 17 / 19$ & $11 / 16 / 19$ & $1 / 21 / 20$ & 171000 & 555 & 0 & \\
\hline$A Y-102$ to $A N-103$ & $1 / 21 / 20$ & $1 / 19 / 20$ & $1 / 22 / 20$ & 358100 & 3151 & 0 & 1 \\
\hline AX-101 to AY-102 & $1 / 22 / 20$ & $1 / 21 / 20$ & $3 / 4 / 20$ & 110400 & 358 & 0 & \\
\hline $\mathrm{C}-102$ to $\mathrm{AY}-102$ & $1 / 22 / 20$ & $1 / 19 / 20$ & $3 / 4 / 20$ & 178600 & 6547 & 0 & \\
\hline AY -102 to $A N-103$ & $3 / 4 / 20$ & $3 / 3 / 20$ & $3 / 5 / 20$ & 21727 & 490 & 0 & 3 \\
\hline AY-102 to AW-101 & $3 / 5 / 20$ & $3 / 2 / 20$ & $3 / 6 / 20$ & 268600 & 6049 & 0 & \\
\hline C-102 to AY-102 & $3 / 6 / 20$ & $3 / 1 / 20$ & $5 / 20 / 20$ & 319200 & 11701 & 0 & \\
\hline C-103 to AY-102 & $3 / 6 / 20$ & $2 / 29 / 20$ & $5 / 20 / 20$ & 424700 & 16738 & 0 & \\
\hline AY-102 to AN-101 & $5 / 20 / 20$ & $5 / 10 / 20$ & $5 / 24 / 20$ & 744800 & 28047 & 0 & \\
\hline C-102 to AY-102 & $5 / 24 / 20$ & $5 / 19 / 20$ & $8 / 7 / 20$ & 319200 & 11701 & 0 & \\
\hline C-109 to AY-102 & $5 / 24 / 20$ & $5 / 19 / 20$ & $8 / 7 / 20$ & 301800 & 11509 & 0 & \\
\hline SY-102 to AN-104 & $6 / 10 / 20$ & $6 / 1 / 20$ & $6 / 14 / 20$ & 976500 & 24798 & 0 & 8 \\
\hline AN-104 to AW-103 & $6 / 14 / 20$ & $6 / 6 / 20$ & $6 / 18 / 20$ & 842900 & 21068 & 0 & 2 \\
\hline AN-104 to AN-101 & $6 / 18 / 20$ & $6 / 16 / 20$ & $6 / 19 / 20$ & 135000 & 3364 & 0 & \\
\hline $\mathrm{AY}-102$ to $\mathrm{AN}-101$ & $8 / 7 / 20$ & $8 / 6 / 20$ & $8 / 7 / 20$ & 53400 & 1995 & 0 & 8 \\
\hline $\mathrm{AY}-102$ to $\mathrm{AN}-102$ & $8 / 7 / 20$ & $7 / 30 / 20$ & $8 / 10 / 20$ & 568600 & 21223 & 0 & \\
\hline SX-103 to SY-101 & $8 / 7 / 20$ & $8 / 5 / 20$ & $1 / 15 / 21$ & 466000 & 2986 & 0 & \\
\hline SX-105 to SY-101 & $8 / 7 / 20$ & $8 / 5 / 20$ & $1 / 15 / 21$ & 410200 & 4236 & 0 & \\
\hline $\mathrm{AY}-102$ to $\mathrm{AN}-102$ & $8 / 13 / 20$ & $8 / 12 / 20$ & $8 / 14 / 20$ & 22338 & 821 & 0 & \\
\hline S-111 to SY-103 & $8 / 13 / 20$ & $7 / 31 / 20$ & $4 / 27 / 21$ & 1079000 & 37085 & 0 & \\
\hline C-108 to AY-102 & $8 / 14 / 20$ & $8 / 11 / 20$ & $10 / 27 / 20$ & 194200 & 7263 & 0 & \\
\hline SY -102 to $\mathrm{AN}-104$ & $10 / 5 / 20$ & $9 / 26 / 20$ & $10 / 9 / 20$ & 977000 & 24298 & 0 & 2 \\
\hline AN-104 to AN-102 & $10 / 9 / 20$ & $10 / 7 / 20$ & $10 / 10 / 20$ & 222300 & 5527 & 0 & 7 \\
\hline $\mathrm{AN}-104$ to AP-106 & $10 / 10 / 20$ & $10 / 3 / 20$ & $10 / 14 / 20$ & 755700 & 18773 & 0 & \\
\hline $\mathrm{AY}-102$ to $\mathrm{AP}-106$ & $10 / 27 / 20$ & $10 / 24 / 20$ & $10 / 28 / 20$ & 185300 & 6900 & 0 & 1 \\
\hline $\mathrm{AY}-102$ to AP-101 & $10 / 28 / 20$ & $10 / 27 / 20$ & $10 / 28 / 20$ & 9889 & 363 & 0 & \\
\hline
\end{tabular}

To convert gal to L multiply by $\mathbf{3 . 7 8 5}$. 


\section{References}

HNF-SD-WM-SP-012, 1999, Tank Waste Remediation System Operation and Utilization Plan to Support Waste Feed Delivery, Rev. 1, Numatec Hanford Corporation, Lockheed Martin Hanford Corporation, and COGEMA Engineering Corporation for Fluor Daniel Hanford Inc., Richland, Washington

RPP-5227, 2000, Waste Feed Delivery Raw Water Capability Evaluation, CH2M HILL Hanford Group, Inc., Richland, Washington.

RPP-5228, 2000, Assessment of the Requirements of Electrical Power for Continued Safe Storage and Waste Feed Delivery, CH2M HILL Hanford Group, Inc., Richland, Washington. 
RPP-6023 REV 0

\section{APPENDIX B}

\section{CHECKLIST FOR INDEPENDENT REVIEW}


RPP-6023 REV 0

This page intentionally left blank. 


\section{CHEXKLIST POR INDEPENDENT REVIEW}

Doctutuext:

Anthor:

Scope of Review;

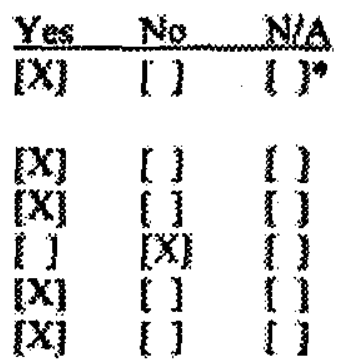

Non-Radioactive Chetutcal Soutce Term for the Dovblenshell

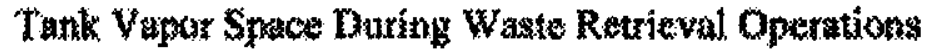
T. H. May, al.

Review data and the associsted sounce temu preadsheet.

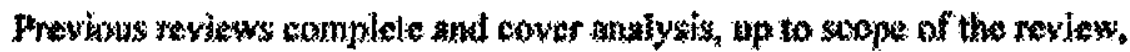
with no gras.

Problem rompletely defined.

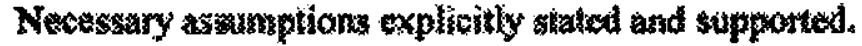

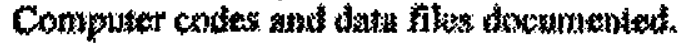

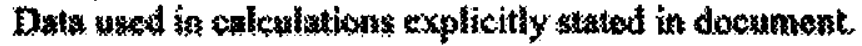

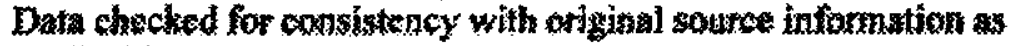
applicables.

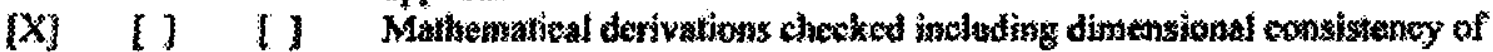

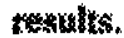

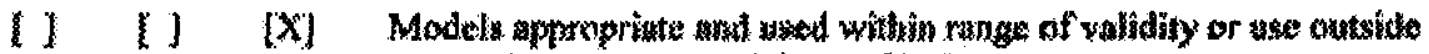
rarige of estably

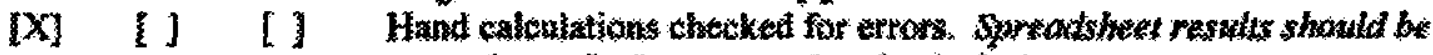

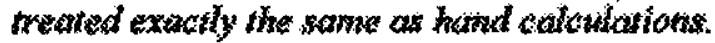

$1 \quad[\mathrm{X})$

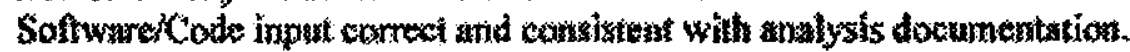

(1) I $]$ [X]

(X] [1] [ ]

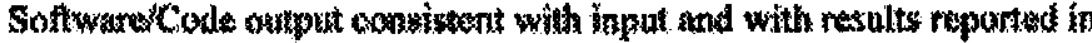
artalysic docizantation.

$\begin{array}{lll}{[x]} & 1 & 11 \\ {[x]} & 1\end{array}$

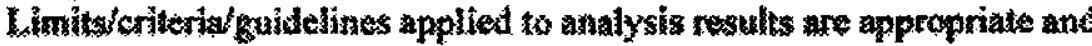

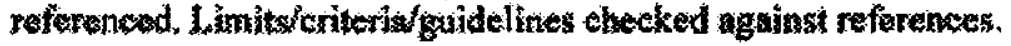

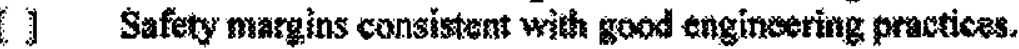

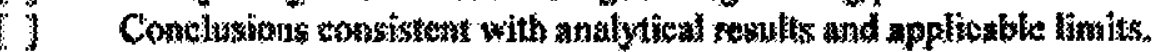

(1) Resuls and conslusionis address all points tequired in the problern statentent.

[X] [ ] [ Fozmat consistent with approprate stakdaris.

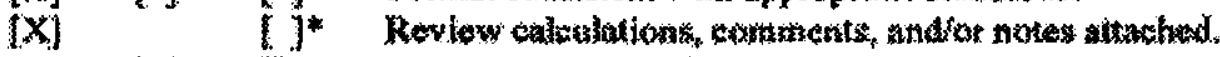

(1) $1 \mathrm{X}$ Document approwexl.

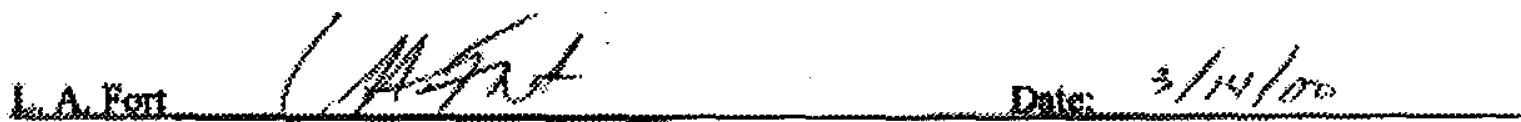

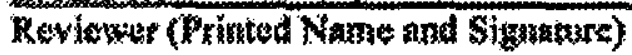

- Any caleulation, comments, or notes generated as part of this review whould be signed, dated,

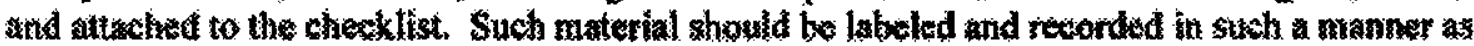

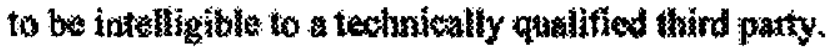

Caxn:aents:

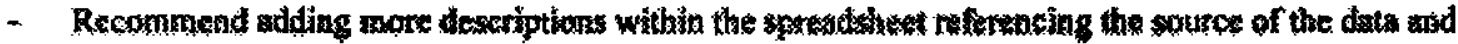

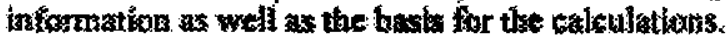

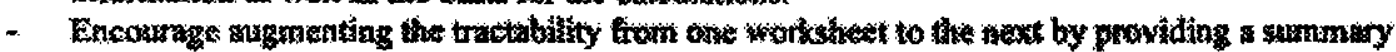

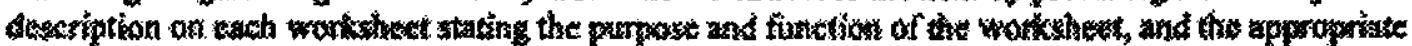
reteresticks.

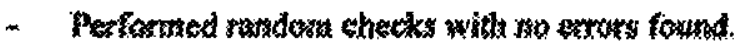




\section{RPP-6023 REV 0}

This page intentionally left blank. 


\section{RPP-6023 REV 0}

\section{APPENDLX C}

\section{UNIT CONCENTRATION FACTORS FROM ISC3}


RPP-6023 REV 0

This page intentionally left blank. 
DON'T SAY IT -- Write It!

To: John S. Hill

$46-25 \quad 372-1617$
September 27. 1996

From: Paul D. Rittmann H0-31 $376-8715$

Subject: Unit Concentration Factors from ISC3

The ISC3 program (EPA-454/B-95-003a. "User's Guide for the Industrial Source Complex. (ISC3) Dispersion Mode1s". September 1995) was used to compute unit concentration factors for the Hanford Site boundary for 24 hour and annual releases from the $100-\mathrm{N}$ (or $100-\mathrm{K}$ ), the 200 West. the 200 East. and 300 Areas. Hanford site wind data is used for these calculations. The data for each area was collected in that area. For the 24 hour releases, hourly data from 1992. 1993. 1994. and 1995 was used. For the annual releases the joint frequency summary for each area for the years 1986 to 1995 was used. Results are sumarized in the first table below. These are the worst-case values for ground level releases from each area.

Tabie 1. Summary of Unit Concentration Factors for Ground Level Releases from Hanford FaciTities

\begin{tabular}{|c|c|c|c|c|}
\hline \multirow[b]{2}{*}{$\begin{array}{l}\text { Release } \\
\text { Locations }\end{array}$} & \multicolumn{2}{|c|}{24 Hour Average } & \multicolumn{2}{|c|}{ Annual Average } \\
\hline & $\begin{array}{l}\text { Concen. } \\
\text { Factor }\end{array}$ & $\begin{array}{c}\text { Site Boundary } \\
\text { Location }\end{array}$ & $\begin{array}{l}\text { Concen. } \\
\text { Factor }\end{array}$ & $\begin{array}{c}\text { Site Boundary } \\
\text { Location }\end{array}$ \\
\hline $\begin{array}{l}100-\mathrm{N} \& \mathrm{KW} \\
200 \text { West Area } \\
200 \text { East Area } \\
300 \text {. Area }\end{array}$ & $\begin{array}{l}4.17 \\
3.46 \\
2.79 \\
38.1 \\
\end{array}$ & $\begin{array}{r}8.5 \mathrm{~km} \text { WM } \\
12.6 \mathrm{~km} \mathrm{~S} \\
17.1 \mathrm{~km} \text { ESE } \\
1.1 \mathrm{~km} \mathrm{E} \\
\end{array}$ & $\begin{array}{l}0.125 \\
0.0585 \\
0.0793 \\
1.56 \\
\end{array}$ & $\begin{array}{r}8.5 \mathrm{~km} \text { WW } \\
22.0 \mathrm{~km} \mathrm{SE} \\
17.1 \mathrm{~km} \text { ESE } \\
1.3 \mathrm{~km} \mathrm{NE} \\
\end{array}$ \\
\hline \multicolumn{5}{|c|}{$\begin{array}{l}\text { Note: Units for the Concentration Factors are } \mu \mathrm{g} / \mathrm{m}^{3} \text { per } \mathrm{g} / \mathrm{s} \text {. } \\
\text { ' Peak values are given. } \\
\text { Note: Annual averages are based on Hanford Site wind data } \\
\text { collected over the years } 1986 \text { to } 1995 \text {. } \\
24 \text { hour averages are based on hourly Hanford Site wind data } \\
\text { for the years } 1992 \text {, } 1993 \text {. 1994. and } 1995 \text {. }\end{array}$} \\
\hline
\end{tabular}

To use these factors. the rate at wich a chemical is released into the air must be computed. To do this, the total amount (in grams) of the chemical released is divided by either 86,400 seconds ( 24 hours) or 31.557 .600 seconds (1 year). This release rate is then multiplied by one of the factors on Table 1 to compute the average concentration at the Hanford site boundary in $\mu \mathrm{g} / \mathrm{m}^{3}$. The formula below sumarizes the calculation.

$$
\text { Air Conc }\left(\mu \mathrm{g} / \mathrm{m}^{3}\right)=\frac{\text { (Total Release, grams }) * \text { (Concen. Factor.) }}{\text { Release Period, seconds }}
$$

As an example. suppose that 10 grams of ammonia is released over a 24 hour period from the 200 West Area. Then the largest observed air concentration at the Hanford site boundary over the past four years is $0.0004 \mu \mathrm{g} / \mathrm{m}^{3}$ at a location $12.6 \mathrm{~km}$ south of the 200 West Area.

$$
\frac{(10 \mathrm{grams}) *\left(3.46 \mu \mathrm{g} / \mathrm{m}^{3} \mathrm{per} \mathrm{g} / \mathrm{s}\right)}{86,400 \text { seconds }}=4.0 \times 10^{-4} \mu \mathrm{g} / \mathrm{m}^{3}(12.6 \mathrm{~km} \mathrm{~S})
$$


RPP-6023 REV 0

September 27, 1996

DSI

Page 2

Method of Calculatina the Concentration Factors

The first step was to estimate distances to the Hanford Site boundary from each of the areas of interest in a 1116 wind transport directions. Table 2 shows the facilities selected and the distances obtained from the Hanford Map Distance (HMD) software by P.D. Rittmann.

Table 2. Distances (meters) to the Hanford Site Boundary

\begin{tabular}{|c|r|r|r|r|r|r|r|r|}
\hline \multirow{2}{*}{ Dir } & \multicolumn{2}{|c|}{$100-\mathrm{N}$ and $-\mathrm{K}$} & \multicolumn{2}{|c|}{200 West } & \multicolumn{2}{|c|}{200 East } & \multicolumn{2}{|c|}{300 Area } \\
\cline { 2 - 9 } & $100 \mathrm{~N}$ & $100 \mathrm{KW}$ & CWC & REDOX & PUREX & WESF & 324 & 333 \\
\hline N & 9600 & 11000 & 17300 & 20300 & 24600 & 19400 & 7000 & 8700 \\
NWW & 8700 & 8900 & 15500 & 18100 & 21200 & 16700 & 46000 & 45500 \\
NW & 8300 & 8700 & 14600 & 17200 & 21300 & 18100 & 48600 & 48100 \\
WWN & 8500 & 10100 & 11800 & 13200 & 21200 & 19300 & 28500 & 28200 \\
W & 11500 & 12100 & 11500 & 13000 & 20700 & 18900 & 6000 & 6700 \\
WSW & 17300 & 15700 & 11800 & 13300 & 21100 & 19400 & 3500 & 4200 \\
SW & 20500 & 17400 & 13800 & 15500 & 17100 & 19900 & 2400 & 2900 \\
SSW & 28600 & 25600 & 15100 & 12800 & 16800 & 19600 & 2000 & 2700 \\
S & 28600 & 25200 & 14700 & 12600 & 19600 & 22800 & 1900 & 2400 \\
SSE & 34100 & 31000 & 19200 & 18200 & 19800 & 25500 & 1900 & 2400 \\
SE & 27300 & 32100 & 24700 & 22000 & 24300 & 19900 & 1500 & 1700 \\
ESE & 19100 & 21700 & 29900 & 28700 & 20200 & 17100 & 1200 & 1400 \\
E & 17300 & 20000 & 24300 & 25000 & 16000 & 16900 & 1100 & 1300 \\
ENE & 17300 & 20400 & 24600 & 23200 & 15300 & 21900 & 1100 & 1300 \\
NE & 16300 & 19900 & 27400 & 26400 & 18100 & 26400 & 1300 & 1500 \\
NNE & 13800 & 15200 & 25000 & 28800 & 23600 & 21100 & 1800 & 2200 \\
\hline
\end{tabular}

The second step was to obtain Hanford Site wind data from Kenneth $W$. Burk at PNNL. The wind data for each area is then used in the ISC3 calculations.

The third step is to create input files for the ISC3 software. Two of the input files are attached for reference: The first is an annual average calculation using ISCLT, while the second is a 24 hour calculation using ISCST: Both use a release height of 2 meters. with an exhaust flow rate of $2000 \mathrm{cfm}$ at a temperature of $20^{\circ} \mathrm{C}$. These conditions model ground level releases.

The final step was to arrange the ISC3 results into Tables 3 and 4. The worst case concentration factor was taken for each area. These worst-case results are listed in Table 1. 
Table 3. Annual Average Concentration Factors $\left(\mu g / m^{2}\right.$ per $\left.g / s\right)$ from Ground Level Releases

\begin{tabular}{|c|c|c|c|c|c|c|c|c|}
\hline \multirow{2}{*}{ Dir } & \multicolumn{2}{|c|}{$100-\mathrm{N}$ and $-\dot{K}$} & \multicolumn{2}{|c|}{200 West } & \multicolumn{2}{|c|}{200 East } & \multicolumn{2}{|c|}{300 Area } \\
\cline { 2 - 9 } & $100 \mathrm{~N}$ & $100 \mathrm{KW}$ & CWC & REDOX & PUREX & WESF & 324 & 333 \\
\hline N & 0.0500 & 0.0410 & 0.0249 & 0.0200 & 0.0136 & 0.0187 & 0.145 & 0.106 \\
NNW & 0.0656 & 0.0635 & 0.0311 & 0.0251 & 0.0216 & 0.0300 & 0.011 & 0.012 \\
WW & 0.1064 & 0.0993 & 0.0381 & 0.0303 & 0.0220 & 0.0276 & 0.014 & 0.014 \\
WWW & 0.1252 & 0.0973 & 0.0351 & 0.0299 & 0.0173 & 0.0197 & 0.017 & 0.017 \\
W & 0.0863 & 0.0803 & 0.0290 & 0.0243 & 0.0150 & 0.0171 & 0.059 & 0.050 \\
WSW & 0.0373 & 0.0427 & 0.0233 & 0.0196 & 0.0112 & 0.0126 & 0.079 & 0.060 \\
SW & 0.0234 & 0.0293 & 0.0212 & 0.0179 & 0.0154 & 0.0124 & 0.157 & 0.117 \\
SSW & 0.0126 & 0.0146 & 0.0246 & 0.0312 & 0.0153 & 0.0123 & 0.403 & 0.255 \\
S & 0.0136 & 0.0161 & 0.0366 & 0.0457 & 0.0147 & 0.0119 & 0.992 & 0.696 \\
SSE & 0.0131 & 0.0148 & 0.0368 & 0.0396 & 0.0189 & 0.0133 & 1.171 & 0.823 \\
SE & 0.0230 & 0.0186 & 0.0500 & 0.0585 & 0.0289 & 0.0380 & 1.248 & 1.036 \\
ESE & 0.0504 & 0.0423 & 0.0532 & 0.0562 & 0.0629 & 0.0793 & 1.142 & 0.917 \\
E & 0.0661 & 0.0520 & 0.0505 & 0.0486 & 0.0585 & 0.0542 & 1.184 & 0.933 \\
ENE & 0.0555 & 0.0442 & 0.0306 & 0.0331 & 0.0366 & 0.0224 & 1.382 & 1.082 \\
NEE & 0.0389 & 0.0295 & 0.0182 & 0.0191 & 0.0207 & 0.0124 & 1.558 & 1.256 \\
NNE & 0.0318 & 0.0277 & 0.0153 & 0.0127 & 0.0117 & 0.0136 & 0.975 & 0.719 \\
\hline
\end{tabular}

Table 4. 24 Hour Average Concentration Factors $\left(\mu \mathrm{g} / \mathrm{m}^{3}\right.$ per $\mathrm{g} / \mathrm{s}$ ) from Ground Level Releases

\begin{tabular}{|c|c|c|c|c|c|c|c|c|}
\hline \multirow{2}{*}{ Dir } & \multicolumn{2}{|c|}{$100-\mathrm{N}$ and $-\mathrm{K}$} & \multicolumn{2}{c|}{200 West } & \multicolumn{2}{c|}{200 East } & \multicolumn{2}{c|}{300 Area } \\
\cline { 2 - 8 } & $100 \mathrm{~N}$ & $100 \mathrm{KW}$ & CWC & REDOX & PUREX & WESF & 324 & 333 \\
\hline N & 3.75 & 3.30 & 1.96 & 1.70 & 1.29 & 1.71 & 5.91 & 4.47 \\
NNW & 3.20 & 3.13 & 3.30 & 2.84 & 1.95 & 2.45 & 0.52 & 0.53 \\
NWW & 2.29 & 2.17 & 0.78 & 0.64 & 0.53 & 0.62 & 0.29 & 0.30 \\
WNW & 4.17 & 3.51 & 2.16 & 1.94 & 1.16 & 1.28 & 1.12 & 1.13 \\
W & 2.51 & 2.35 & 3.24 & 2.91 & 1.74 & 1.89 & 4.25 & 3.66 \\
WSW & 1.42 & 1.57 & 1.90 & 1.69 & 0.29 & 0.32 & 6.05 & 5.08 \\
SW & 0.81 & 0.96 & 0.79 & 0.71 & 1.31 & 1.13 & 4.79 & 3.97 \\
SSW & 0.92 & 1.02 & 1.92 & 2.30 & 1.39 & 1.20 & 1.91 & 8.91 \\
S & 0.90 & 1.01 & 3.02 & 3.46 & 1.69 & 1.48 & 7.25 & 9.85 \\
SSE & 0.81 & 0.90 & 2.64 & 2.78 & 1.31 & 1.02 & 0.01 & 5.84 \\
SE & 0.51 & 0.41 & 0.99 & 1.12 & 1.00 & 1.29 & 6.44 & 3.08 \\
ESE & 1.62 & 1.44 & 2.51 & 2.61 & 2.36 & 2.79 & 8.42 & 4.65 \\
E & 3.23 & 2.76 & 2.44 & 2.38 & 1.73 & 1.64 & 8.11 & 0.78 \\
ENE & 2.71 & 2.30 & 1.69 & 1.78 & 1.10 & 0.73 & 7.63 & 2.98 \\
NE & 0.61 & 0.48 & 0.91 & 0.95 & 0.41 & 0.26 & 1.38 & 8.12 \\
NWE & 2.36 & 2.15 & 1.96 & 1.70 & 0.97 & 1.08 & 6.36 & 3.08 \\
\hline
\end{tabular}




\section{RPP-6023 REV 0}

September 27. 1996

ISCLT Input File for $100 \cdot \mathrm{N}$ Area

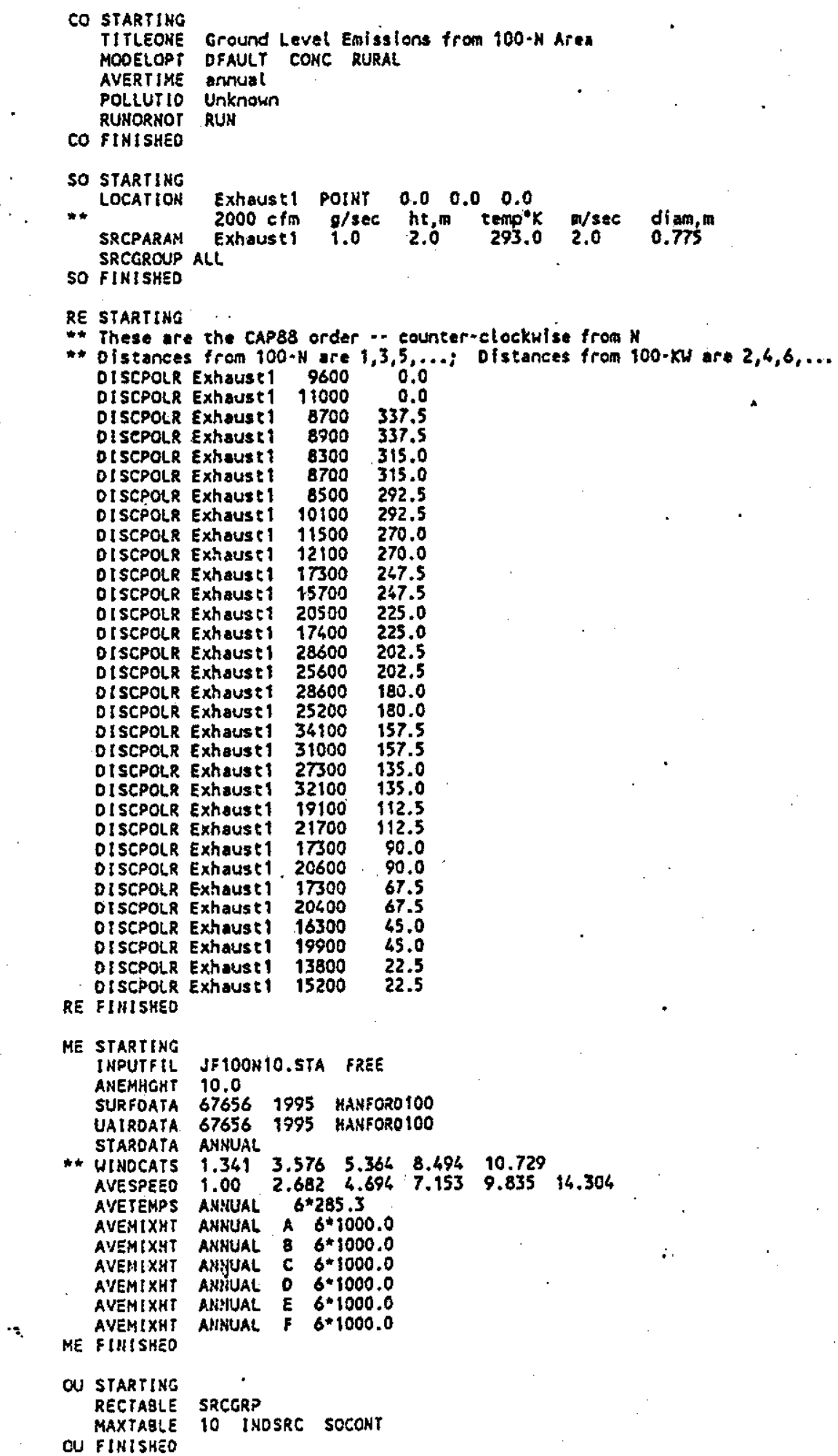


ISCST Input File for 200 West Area

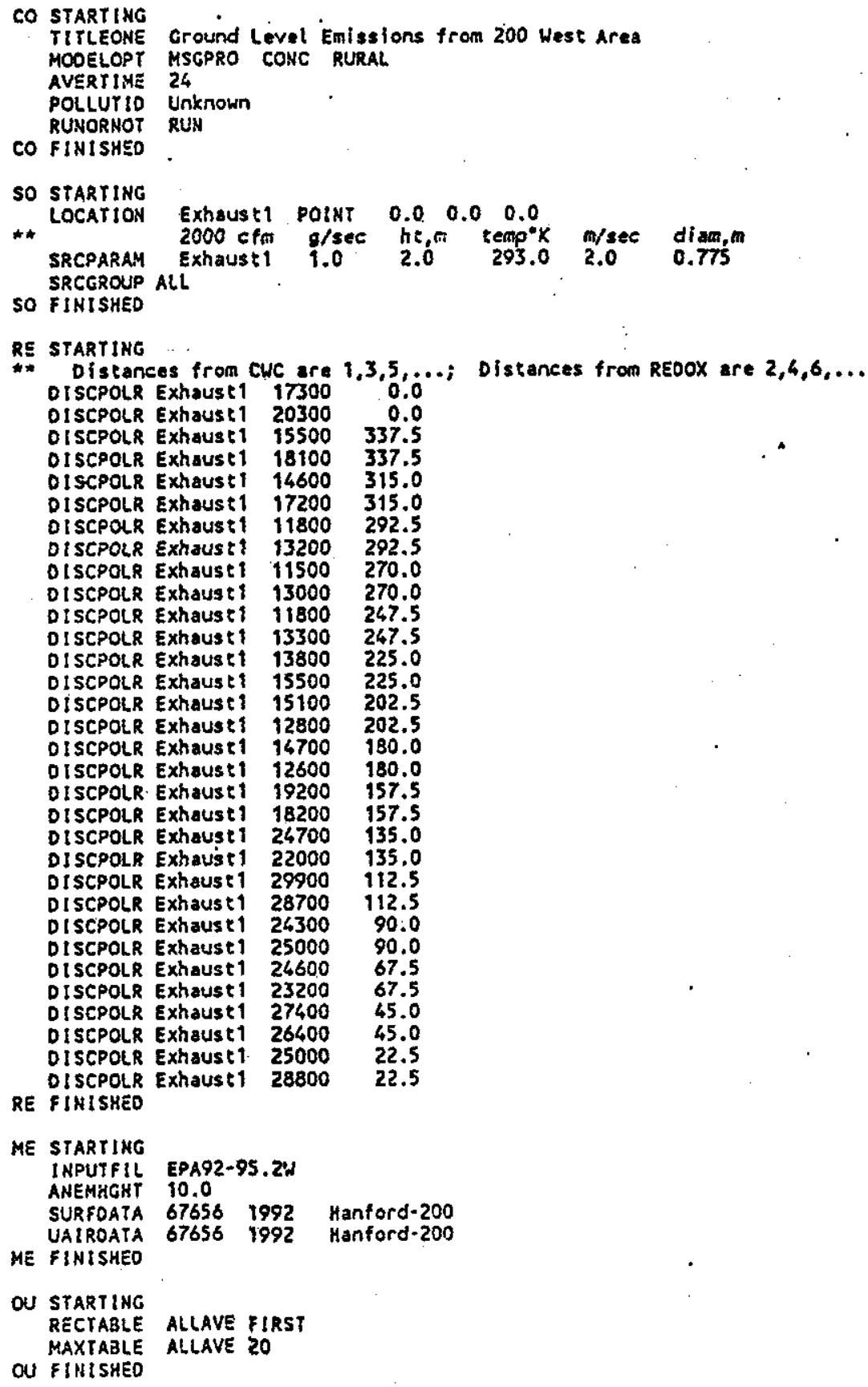




\section{RPP-6023 REV 0}

This page intentionally left blank. 
RPP-6023 REV 0

APPENDIX D

AN AEROSOL PRIMER

BY

J. L. HUCKABY 
RPP-6023 REV 0

This page intentionally left blank. 
RPP-6023 REV 0

\section{APPENDIX D}

\section{AN AEROSOL PRIMER}

This appendix is a partial reprint of Appendix A ("An Aerosol Primer" [by J. L. Huckaby]) from (WHC-SD-WM-ER-181). It provides convenient definitions and summaries of aerosol behaviors. The italicized text and bolding are added for emphasis:

The term aerosol refers to a collection of suspended solids or liquid particles in a gas. Fogs, smogs, clouds, smoke, and fumes are aerosols. Household aerosol spray cans generate an aerosol of whatever liquid is in the can; the compressed gas that forces the liquid out is not an aerosol.

Generally, an aerosol consists of solid and/or liquid particles having diameters in the $100 \mu \mathrm{m}$ to $0.01 \mu \mathrm{m}$ range. In terms of more common objects, coarse human hair is about $100 \mu \mathrm{m}$ thick, soap bubble films are about $1 \mu \mathrm{m}$ thick, smaller cigarette smoke particles are about $0.1 \mu \mathrm{m}$ in diameter, and a typical virus has a diameter of about $0.01 \mu \mathrm{m}$ (Hinds 1982). Particles with a diameter of less than about $0.1 \mu \mathrm{m}$ are easily suspended and their motion tends to be controlled by diffusion (i.e., Brownian motion) (Hinds 1982). For larger particles, having diameters between about 0.1 and $1 \mu \mathrm{m}$, the effects of diffusion and gravitational settling are both important to particle motion. Still larger particles, with diameters greater than about $1 \mu \mathrm{m}$, tend to be more strongly influenced by gravitational settling than by diffusion.

An important property of aerosols is that they have large surface areas per unit volume of the particulate phase. This allows a maximum of interface between the condensed phase and the vapor phase, and promotes rapid establishment of the vaporliquid equilibrium. While a small puddle of water can set for hours in a room with $50 \%$ relative humidity, the same amount of water sprayed into the room as an aerosol of $1 \mu \mathrm{m}$ droplets would evaporate in less than 1 second. The large surface area per unit volume of the condensed phase also enhances the ability of a liquid aerosol to scrub soluble vapors from the ambient gas. Furthermore, for most practical purposes (a notable exception being a moving flame front) there are no thermal or concentration gradients within individual liquid droplets to impede the establishment of gas phase - droplet phase equilibrium (Huckaby 1986).

One property of aerosols that is relevant here is that they scatter visible light. This makes the aerosol visible to the naked eye even though the individual aerosol droplets may be too small to be visible. Aerosols of clear liquids, such as water and normal paraffin hydrocarbon (NPH), appear white in white light, and attenuate the light passing through them. This means that if a non-trivial aerosol is present in a waste tank, it will be visible (given adequate light in the headspace). Furthermore, if a waste tank aerosol appears diffuse (as opposed to thick or milky), it has a relatively low number of droplets per unit volume, and a correspondingly low mass per unit volume. The appearance of an aerosol as a very dense fog does not, however, imply that it contains a great deal of mass in the droplet phase. Very thick, milky fogs can occur as a result of a large number of 
very small droplets per unit volume, and yet actually have a relatively low mass in droplet form.

Aerosols can be generated by subdivision of bulk material (e.g., fine wood dusts or atomized liquids from spray cans) or by condensation of a supersaturated vapor in a gas. In the (ambient) waste tanks the mechanism is condensation. An example of a condensation aerosol occurs when you take a shower: air becomes warmed and virtually saturated with water vapor in the shower and rises. A fog or mist begins to form near the ceiling since contact with the ceiling cools the warm vapor-laden air below its dew point temperature. Settling mist evaporates as it falls, eventually saturating lower regions with water vapor. Since the mist cannot evaporate in vapor-saturated air, the layer of fog along the ceiling appears to get thicker as the mist falls further and further before evaporating. Eventually, if the shower is left on, the entire room will be filled with a fog.

Technically, the condensation of a supersaturated vapor to form an aerosol particle can occur via homogeneous or heterogeneous nucleation. Homogeneous nucleation requires very specialized conditions and is not a significant mechanism in the waste tanks. Heterogeneous nucleation involves the condensation of vapor on fine particles or ions already present in the gas. Airborne dust particles introduced to a fog-producing waste tank serve as sites for the condensation of vapor, and are eventually "rained out" of the air space as the fog droplets grow and fall (if not removed by ventilation). This process is so effective, it is the basis of certain ultra-clean room technologies. Waste tanks that have fogs in their headspaces are consequently not apt to have significant amounts of suspended radioactive dusts.

In principle the dynamic generation of fog droplets in the waste tanks via heterogeneous nucleation would eventually remove dust and ions from the tank air space and leave no sites for further heterogeneous nucleation. This does not occur, however, since the ionizing radiation within the tanks generates an ample supply of ions from air molecules to serve as nucleation sites and maintain the process.

Condensation aerosols in a nuclei-rich environment, such as the headspace of tank 241-C-103, typically have small average particle diameters. As the droplet size in an aerosol decreases, settling and coagulation effects decrease, making it possible to have more droplets per unit volume. However, a very dense aerosol having a relatively small average droplet diameter $(e . g ., 0.3 \mu \mathrm{m})$ will have much less droplet phase mass per unit volume that a relatively diffuse aerosol with a much larger (e.g., $3 \mu \mathrm{m})$ average droplet diameter.

An aerosol having $10 \mathrm{mg}$ per liter of liquid in the droplet phase would be considered to be a very concentrated aerosol (from conversations with other aerosol scientists, particularly M.W. Ligotke of Pacific Northwest Laboratories). While it is certainly possible to generate aerosols having densities greater than $10 \mathrm{mg}$ per liter $\left(10,000 \mathrm{mg} / \mathrm{m}^{3}\right)$, special conditions would be required to sustain them. To give some perspective, typical atmospheric fogs have a mass concentration of about $0.01 \mathrm{mg}$ per liter $\left(10 \mathrm{mg} / \mathrm{m}^{3}\right)$ (Hinds 1982). 


\section{RPP-6023 REV 0}

\section{REFERENCES}

Hinds, W. C., 1982, Aerosol Technology/Properties, Behavior, and Measurement of Airborne Particles, John Wiley \& Sons, New York, New York.

Huckaby, J. L. 1986, Absorption of Sulfur Dioxide by Growing and Evaporating Water Droplets, Master's Thesis, University of Kentucky, Lexington, Kentucky.

WHC-SD-WM-ER-181, 1992, An Engineering Assessment of the Aerosol and Vapor Flammability in 241-C-103, Rev. 0, Westinghouse Hanford Company, Richland, Washington. 
RPP-6023 REV 0

This page intentionally left blank. 
RPP-6023 REV 0

\section{APPENDIX E}

HENRY'S LAW CONSTANT FOR AMMONIA 
RPP-6023 REV 0

This page intentionally left blank. 


\section{HENRY'S LAW CONSTANT FOR AMMONIA}

This section is extracted from RPP-4941. The equilibrium concentrations of gases that exist between the vapor phase and aqueous solutions can be represented by the Henry $=s$ Law expression.

$$
\mathrm{X}_{\ni} \mathrm{K}_{\mathrm{H}} \mathrm{p}
$$

where $p$ is the partial pressure of a particular gas expressed in atmospheres, $K_{H}$ is the Henry=s Law constant for that gas, and $\mathrm{X}$ is the concentration of that gas in the aqueous solution. The Henry $=s$ Law constant for a gas depends on several variables, including temperature and the concentrations of the various ions in solution.

Of the models reviewed in Composition and Quantities of Retained Gas Measured in Hanford Waste Tanks 241-AW-101, A-101, $A N-105, A N-104$, and AN-103, PNNL-11450; the Schumpe model ("Estimation of Gas Solubilities in Salt Solutions, Schumpe 1993) gave the best agreement with experimental values from saturated waste. The Schumpe model is given by Equation 2.

$$
\log \left(c_{G, 0} / c_{G}\right)=\log \left(\frac{K_{H, G} \text { (water) }}{K_{H, G}(\text { solution })}\right)=\sum_{i}\left(h_{i}+h_{G}\right) c_{i}
$$

where $\mathrm{c}_{\mathrm{G}, 0}$ and $\mathrm{c}_{\mathrm{G}}$ denote the gas solubility of gas $\mathrm{G}$ in pure water and in a salt solution, respectively; $\mathrm{K}_{\mathrm{H}, \mathrm{G}}$ (water) and $\mathrm{K}_{\mathrm{H}, \mathrm{G}}$ (solution) are Henry=s Law constants for soluble gas $\mathrm{G}$ in pure water and salt solutions; $h_{i}$ and $h_{G}$ are the ion and gas-specific coefficients; and $c_{i}(\mathrm{~mol} / L)$ is the concentration of ion $\mathrm{Ai} \cong$ in the salt solution. The gas-specific constant, $h_{G}$, is assumed to be a linear function of temperature.

The $h_{G, 0}$ is the reference value, and $h_{T}$ is the temperature-specific coefficient.

Values of $h_{\mathrm{G}, 0}$ and $h_{\mathrm{T}}$ for ammonia, hydrogen, and methane are given in Table E-1.

The terms $3 c_{i}$ and $3 h_{i} c_{i}$ are calculated using ion concentrations obtained from a variety of sources, including the best-basis data and tank characterization data and assumptions based on similar waste types. The values for the ion-specific constants $h_{i}$ are presented in Table E-2. 
Table E-1. Values of $h_{G, 0}$ and $h_{T}{ }^{1}$.

\begin{tabular}{|c|c|c|}
\hline Gas & $\mathbf{h}_{\mathbf{T}}, \frac{\mathbf{L}}{\mathbf{m o l e}^{\circ} \mathbf{K}}$ & $\mathbf{h}_{\mathbf{G}, \mathbf{0}}, \frac{\mathbf{L}}{\mathbf{m o l e}}$ \\
\hline Ammonia & $0^{*}$ & -0.0481 \\
\hline Hydrogen & $-2.99 \mathrm{E}-4$ & -0.0218 \\
\hline Methane & $-5.24 \mathrm{E}-4$ & 0.0022 \\
\hline
\end{tabular}

Weisenberger, S., and A. Schumpe, 1996, "The Estimation of Gas Solubilities in Salt Solutions at Temperature from $273^{\circ} \mathrm{K}$ to $363^{\circ} \mathrm{K}$," AIChE Journal, vol. 42, p. 299.

${ }^{*} h_{\mathrm{T}}$ for ammonia is set equal to zero (PNNL-11450) since an experimentally determined value is not available. For temperatures greater than $25^{\circ} \mathrm{C}$, if $\mathrm{h}_{\mathrm{T}}$ were also negative, lower vapor pressures would be predicted. Therefore, setting $h_{T}$ equal to zero is more conservative because higher ammonia vapor pressures would result.

Table E-2. Values of $h_{i}{ }^{1}$.

\begin{tabular}{|l|l|}
\hline \multicolumn{1}{|c|}{ Ion } & \multicolumn{1}{|c|}{$\mathbf{h}_{\mathrm{i}} \frac{\mathrm{L}}{\text { mole }}$} \\
\hline $\mathrm{Na}+1$ & 0.1143 \\
\hline $\mathrm{Al}+3$ & 0.2174 \\
\hline $\mathrm{Fe}+3$ & 0.1161 \\
\hline $\mathrm{Cr}+3$ & 0.0648 \\
\hline $\mathrm{Ni}+2$ & 0.1654 \\
\hline $\mathrm{K}+1$ & 0.0922 \\
\hline $\mathrm{OH}-1$ & 0.0839 \\
\hline $\mathrm{NO} 3-1$ & 0.0128 \\
\hline $\mathrm{NO} 2-1$ & 0.0795 \\
\hline $\mathrm{CO} 3-2$ & 0.1423 \\
\hline $\mathrm{PO} 4-3$ & 0.2119 \\
\hline $\mathrm{SO} 4-2$ & 0.1117 \\
\hline $\mathrm{F}-1$ & 0.0920 \\
\hline $\mathrm{Cl}-1$ & 0.0318 \\
\hline $\mathrm{Li}+1$ & 0.0754 \\
\hline $\mathrm{Br}-1$ & 0.0269 \\
\hline
\end{tabular}

Weisenberger, S., and A. Schumpe, 1996, "The Estimation of Gas Solubilities in Salt Solutions at Temperature from $273^{\circ} \mathrm{K}$ to $363^{\circ} \mathrm{K}$," AIChE Journal, vol. 42, p. 299. 
The various Henry=s Law constants, $\mathrm{K}_{\mathrm{H}, \mathrm{G}}$ (solution), for each tank waste solution are obtained by dividing the appropriate temperature dependent value of $\mathrm{K}_{\mathrm{H}, \mathrm{G}}$ (water) calculated with equation 5 by its corresponding Schumpe ratio of $\mathrm{K}_{\mathrm{H}, \mathrm{G}}$ (water)/K $\mathrm{K}_{\mathrm{H}, \mathrm{G}}$ (solution).

The Henry=s Law constant obtained through the above procedure must be converted from a molal basis, moles of solute per kilogram of solvent (water) in solution, to a basis of moles per volume of solution. The conversion is accomplished by calculating:

$$
\mathrm{K}_{\mathrm{H}}, \mathrm{L} \text { liquid wastebasis }=\left(\mathrm{K}_{\mathrm{H}}, \mathrm{kg} \text { waterbasis }\right) \rho_{\mathrm{L}} \omega_{\mathrm{L}}
$$

where $\omega_{\mathrm{L}}$ is the weight fraction of water in the solution and $\rho_{\mathrm{L}}$ is the solution density.

Equations for Henry=s Law constants are reported for various gases including ammonia, hydrogen, and methane in water (Norton and Pederson 1995). The equation and its source for each gas at 1 atmosphere in equilibrium with water is given below. The equation for methane is correctly reported in PNNL-11450.

Ammonia (Journal of Physical Chemistry, Clegg and Brimblecombe 1989):

$\mathrm{K}_{\mathrm{H}, \mathrm{NH} 3}\left[\right.$ mole $/ \mathrm{kg}$ water-atm] $=\exp [-8.0964+3917.50 / \mathrm{T}-0.00314 \times \mathrm{T}], \mathrm{T}={ }^{\circ} \mathrm{K}$

A description of the dynamic model used is given in Appendix B of RPP-4941.

\section{REFERENCES}

Clegg, S. L., and P. Brimblecombe, 1989, Journal of Physical Chemistry, Vol. 93, p. 7237.

Norton, J. D., and L. R. Pederson, 1995, Solubilities of Gases in Simulated Tank 241-SY-101 Wastes, PNL-10785, Pacific Northwest Laboratory, Richland, Washington.

PNNL-1 1450, 1997, Composition and Quantities of Retained Gas Measured in Hanford Waste Tanks 241-AW-101, A-101, $A N-105, A N-104$, and $A N-103$, Rev. 1, Pacific Northwest National Laboratory, Richland, Washington.

RPP-4941, 2000, Methodology for Predicting Flammable Gas Mixtures in Double-Contained Receiver Tanks, Rev. 0, CH2M HILL Hanford Group, Inc., Richland, Washington.

Schumpe, A., 1993, "Estimation of Gas Solubilities in Salt Solutions," Chem. Eng. Sci., Vol. 48, p. 153.

Weisenberger, S., and A. Schumpe, 1996, "The Estimation of Gas Solubilities in Salt Solutions at Temperature from $273^{\circ} \mathrm{K}$ to $363^{\circ} \mathrm{K}$," AIChE Journal, vol. 42, p. 299. 


\section{RPP-6023 REV 0}

This page intentionally left blank. 
RPP-6023 REV 0

APPENDIX F

GLOSSARY 


\section{RPP-6023 REV 0}

This page intentionally left blank. 
Aging Waste. High level, first cycle solvent extraction waste from the PUREX plant (NCAW).

Complexant Concentrate. Concentrated product from the evaporation of dilute complexed waste

Dilute Complexed Waste. Characterized by high content of organic carbon including organic complexants: EDTA, HEDTA, being the major complexants used. Main sources of dilute complexed waste in the DST system are saltwell liquid inventory from SSTs.

Dilute Non-Complexed Waste. Low activity liquid waste originating from $T$ and $S$ Plants, the 300 and 400 Areas, PUREX facility (decladding supernatant and miscellaneous waste), $100 \mathrm{~N}$ Area (sulfate waste), B Plant, saltwells, and PFP (supernate).

Double-Shell Slurry Feed. Waste concentrated just before reaching the sodium aluminate saturation boundary in the evaporator without exceeding receiver tank composition limits. This form is not as concentrated as DSS.

Double-Shell Slurry. Waste that exceeds the sodium aluminate saturation boundary in the evaporator without exceeding receive tank composition limits. For reporting purposes, DSS is considered solid. 


\section{RPP-6023 REV 0}

This page intentionally left blank. 